\title{
32. WESTERN PACIFIC GUYOTS
}

\author{
B. C. Heezen ${ }^{1}$, J. L. Matthews ${ }^{2}$, R. Catalano ${ }^{3}$, J. Natland ${ }^{2}$, A. Coogan ${ }^{4}$, M. Tharp ${ }^{1}$, and M. Rawson ${ }^{1}$
}

\section{INTRODUCTION}

The geological history of the western Pacific deep sea cannot be deduced from the stratigraphic record of the DSDP holes alone. Other types of information must also be taken in consideration. The guyots of the western Pacific are dip sticks which when dated provide important data and constraints concerning paleobathymetry and eustasy. As a part of the R. V. Thomas Washington ARIES V site survey cruise of May-June, 1971 (preceding Glomar Challenger Leg 20) the opportunity was taken to dredge 16 guyots in the Mid-Pacific Mountains, the Wake seamounts and the Geisha guyots (Figure 1). The data of ARIES V is treated in two separate chapters, Chapter 24 is devoted to acoustical stratigraphy and the exploration for drilling sites, while this chapter treats the guyot data with particular reference to information and conclusions critical to the interpretation of the geological history of the region.

The flat topped seamounts of the Pacific, discovered during World War II, were immediately recognized as sunken islands and speculation commenced on the age and cause of the drowning. In an era when in much of the world continental drift and crustal mobility were excluded as acceptable topics of discussion, Hess (1946) proposed that submergence of the islands below sea level had occurred at the present geographical locations in pre-Cambrian time before the first appearance of reef organisms. However, the first dredging of the guyots by R. Revelle and R. S. Dietz yielded Lower to Middle Cretaceous reef organisms (Hamilton, 1956). The reason for the drowning-whether eustasy, local subsidence of the region, or independent subsidence of the individual pedestals-became a subject of debate which due to lack of further exploration and dredging led to little useful progress.

The guyots of the western Pacific were later employed by Menard (1964) to bolster the anti-drift view that the Mid-Oceanic Ridge is an ephemeral uplift of much more ancient crust in an ocean of essentially constant width. If the Mid-Atlantic Ridge and the East Pacific Ridge were ephemeral features, then, he reasoned, there must be some areas where the shifting or demise of an uplift must have been followed by subsidence. He thought that the guyots of the western Pacific recorded such a history. In fact, he proposed the name "Darwin Rise" for the hypothetical ancient, and now vanished, feature. The summit depths of

\footnotetext{
${ }^{1}$ Lamont-Doherty Geological Observatory, Palisades, New York

${ }^{2}$ Scripps Institution of Oceanography, La Jolla, California.

${ }^{3}$ University of Palermo, Palermo, Italy.

${ }^{4}$ Kent State University, Kent, Ohio.
}

the guyots were not all the same, and by plotting the present summit depths he claimed to be able to recognize the former location of the supposed crest of the vanished ridge. The islands, he imagined, submerged as the rise rapidly collapsed after a mantle convection cell dissipated or moved. The reasoning was that the summits which now lie the deepest subsided the most and thus must mark the former crest. With the gradual acceptance of continental displacements (continental drift, global tectonics, plate tectonics), the hypothetical "Darwin Rise" was an anachronism. Incredibly, it was resurrected when geophysicists noted that a thick, thinly-stratified and widely distributed deeper sedimentary layer occurred in the general area of the guyots and thus may coincide in distribution with the hypothetical rise (Ewing et al., 1968). It was proposed that the acoustic opaque layer represented clastic and volcanic deposits derived from the erosion of the "Darwin Rise". Drilling on Leg 6 brought the first evidence that the opaque layer was not a volcano-clastic pile, but primarily a pelagic oozediagenetic chert sequence.

Meanwhile little more had been done to date the guyots; even when the "Darwin Rise" concept was widely accepted, there was little concern with the assumption that all the islands were supposedly created and destroyed nearly synchronously during a brief catastrophic episode. It will be argued here that our subsequent data supports this seemingly unlikely assumption of synchronity.

It has been recognized since Darwin's time that Pacific island and seamount-lines generally show a progression from active vulcanism, eroded volcanic peaks with small lagoons, deep eroded remnants with large lagoons to atolls, banks, and seamounts. The volcanic centers beneath the Pacific clearly moved in time along relatively straight lines (or vice versa). The explanation of this observation is clear in terms of crustal drift. This evident age gradient caused considerable hesitancy in accepting the assumed nearsimultaneous birth and death of the "Darwin Rise" islands. It is clear that the height of the flat top of a guyot above the surrounding ocean floor gives a minimum measure of the ocean depth at the time of drowning. The depth of the summit below present sea level is the combined effect of subsequent subsidence and eustasy.

That the depth of the oceanic crust beneath mean sea level is a function of crustal age was already obvious more than fifteen years ago to all who accepted the concept of the expanding ocean, but it was not until recently that data was sufficiently numerous and precise to give tentative support to the view that a single depth vs. age curve can be applied to all the major ocean basins with the necessity of only small regional corrections. Thus, given an age of crust in the range of 0 to 50 m.y., a reasonable estimate can be 


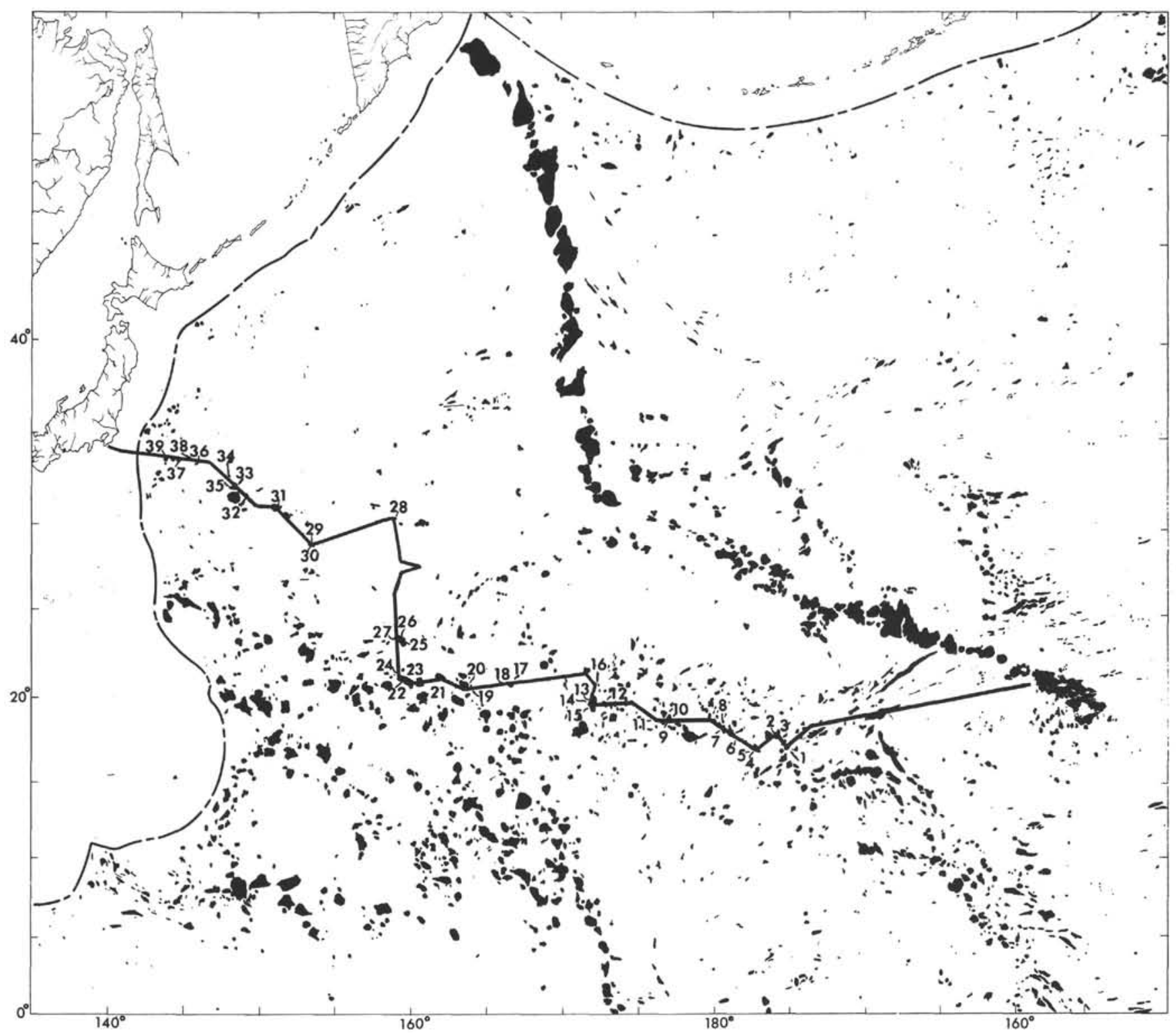

Figure 1. Dredge hauls of Pacific seamounts obtained during the ARIES V expedition of $R$. $V$. Thomas Washington during May and June 1971.

made of depth or vice versa. For greater ages, the relationship is not too helpful since the rate of change of depth with time for crust greater than 100 m.y. old is small and is not yet well determined, and the influence of sediment thickness, sediment loading, and variation in initial depth become important considerations which are, to date, not well enough understood. The same pattern of subsidence should be recorded in the depth of guyot tops.

The investigation of the western Pacific guyots was undertaken in conjunction with the site surveys for Leg 20 in order to provide additional data on paleobathymetry and eustasy to aid in the interpretation of the stratigraphic results to be obtained on Leg 20 . Although the drilling of a guyot had not been included in the original Leg 20 plan, it became part of the Leg 20 program when equipment failures during the later part of Leg 20 limited the maximum depth to which the Glomar Challenger could drill. Thus the guyots investigated on the ARIES V cruise of Thomas Washington became relevant to the interpretation of Holes 200, 201, and 202 on Ita Mai Tai Guyot.

The R. V. Thomas Washington departed Honolulu, Hawaii, 7 May 1971 and steamed directly to a proposed site to be drilled by Glomar Challenger on Leg 17 (Figure 1). On arrival at the site near Horizon Ridge, a radio message was received from Dr. E. L. Winterer, Co-Chief Scientist of Glomar Challenger, Leg 17, to the effect that the deepwater site originally planned could not be accommodated in their drilling plan and, therefore, we should not make the proposed site survey. However, he believed that they would have sufficient time to drill a shallow hole within the Mid-Pacific Mountains, and we were requested to seek a perched 500-meter-sediment accumulation in depths less than 3000 meters. We found and surveyed two such areas and transmitted the plots by radio facsimile to the Glomar Challenger. Dr. Winterer then released us from further commitments to Glomar Challenger Leg 17, and we 
proceeded to explore for promising dredge sites in the Mid-Pacific Mountains.

The dredge employed was a heavy chain bag type developed at the Scripps Institution of Oceanography. Directly shackled to the $5 / 8^{\prime \prime}$ trawl wire, it was used without a dredge weight. We have high praise for this well-designed dredge which consistently recovered large hauls.

The first few hauls suffered from our inexperience with the ship and its equipment. Once we were accustomed to the large AGOR traction winch and its tension gauge, our hauls were generally large and obtained in reasonable time. We would have liked to have been able to attempt deeper hauls on escarpments and on the flanks of the seamounts, but were dissuaded by the productivity of the hauls from near the summits and the slowness of the large winch which made deep-sea dredging extremely time consuming. The Leg 17 site exploration was completed near Hess Guyot where we began a search for attractive dredge sites.

\section{DREDGING: SITES AND OBJECTIVES}

Escarpments which gave promise of basement outcrops occur along the southern margin of the Mid-Pacific Mountains. Since the guyot tops in that area had already been dredged, our interest was directed at first to sampling these deeper escarpments. Dredge 1 obtained basalt pebbles from here the top of a 1600-2000 fathom escarpment (Figure 2). The haul was small and tensions were low, indicating that the area had a fairly continuous sediment cover, so it was decided to try the dredge in shallower water on the west flank of the 900 fathom Renard Guyot (Figure 3). Although the dredge hung up on hauls 2 and 3 and was bent and battered, it recovered only nodules and soft limestone. Since Cape Johnson Guyot was nearby (Fig. ure 4), we decided to attempt obtaining more of the mid-Cretaceous material that had previously been dredged there (Hamilton, 1956). Our two attempts were rather discouraging for we failed to recover Cretaceous material, obtaining only Eocene, Pleistocene, and Recent planktonic oozes. The sixth attempt was on the north flank of the large Navoceano Guyot to the northwest of Cape Johnson Guyot. The dredge became entangled with the bottom and was lost (Figure 5).

The rather small, symmetrical, 900-fathom Shepard Guyot near $19^{\circ} \mathrm{N} 179.5^{\prime} \mathrm{W}$ was surveyed and dredged on May 14 (Figure 6). The dredge recovered Lower Cretaceous limestones from the flank of the seamount 1500 meters below the summit (Figure 7). The material is presumably talus which descended from the summit area. A second attempt (dredge no. 8) to sample the west flank of the seamount produced no samples.

We then steamed westerly, crossing two guyots (Shepard and Revelle) and a broad 2600-fathom sediment pond which was underlain by more than 1000 meters of sediments (Figures 8 and 9). A survey made of the 850 -fathom Jacqueline Guyot at $19^{\circ} 20^{\prime} \mathrm{N}, 176^{\circ} 45^{\prime} \mathrm{E}$ was followed by two dredge hauls which recovered Cretaceous material (Figure 10). Dredge 10 near the break-in slope recovered algae and rudistids (Figure 11). None of the Mid-Pacific guyots west of Cape Johnson Guyot had been dredged prior to ARIES V (Figure 12). We reasoned that the similarity of material recovered by us from Jacqueline Guyot to that described from Cape Johnson Guyot (Hamilton, 1956) suggests a synchroneity of submergence for the Mid-Pacific guyots, at least as far west as Jacqueline Guyot. In view of the brief time available, we decided to next investigate guyots at the western limit of the MidPacific Mountains. However, at $19^{\circ} 41^{\prime} \mathrm{N}, 175^{\circ} 16^{\prime} \mathrm{E}$ we crossed an abrupt pinnacle rising from 2300 to 1950 tau (Figure 13). A brief investigation suggested it might lie on an active fracture zone. In dredge haul 11 we recovered only a few small pebbles consisting of manganese crusts and basalt chips. After this brief diversion we proceeded to the west, crossing several attractive guyots (Figure 14) surrounded by a thick accumulation of sediments.

Dredge hauls $12,13,14$, and 15 were made on Menard Guyot (Figure 15). Dredge 12 recovered large slabs of manganese-coated limestones in about 1000 fathoms depth on the eastern flank of the guyot. Dredge 13 recovered manganese-coated orange-colored volcanic breccia from $3000-4000$ meters depth on the north flank of Menard Guyot. Dredge 14 recovered a limestone boulder with a three-inch coating of manganese from 1700 meters on the western flank of the guyot. Due to the small amount of material obtained in Dredge 14, Dredge 15 was made at the same location, recovering $250 \mathrm{lbs}$. of manganese slabs. Fossils were exposed on the undersides of the slabs where they had been ripped from the sea floor. On leaving the Mid-Pacific Mountains and steaming out over the deep northwest Pacific basin, we noticed a fairly steep escarpment which we thought might offer a chance of sampling basement (Figure 16). Dredge 16 recovered barren red clay and a few basalt fragments. The dredge never became hung up on the bottom, and the prospect seemed poor for further attempts at basement dredging since it appeared that a thin layer of sediment covered most of the escarpment. A survey of Darwin Guyot (Figures 17 and 18) was made, but it was decided not to dredge this guyot, and to move on to the west.

Two attempts were made to dredge a guyot in the Wake group (Figure 19) at $21^{\circ} 05^{\prime} \mathrm{N}, 166^{\circ} 32^{\prime} \mathrm{E}$. Dredge 17 came up empty after an encounter with rough bottom. At Dredge Station 18 , the dredge was lost. We had begun the cruise with only three dredges and had now lost all but one. A survey was completed of Woods Hole Guyot (Figure 20) while a new dredge was constructed.

Wilde Guyot another of the Wake group at $21^{\circ} \mathrm{N}, 163^{\prime} \mathrm{E}$ was dredged (Figure 21). However, the oldest fossil material obtained in Dredges 19 and 20 was Eocene pelagic ooze. Volcanic breccia predominated in the hauls. Miami Guyot, still another of the Wake group was dredged at Station 21 which also yielded volcanic breccia and Eocene pelagic chalk (Figure 22). Dredges 22, 23, and 24 from Lamont Guyot in the Wake group at $21^{\circ} 5^{\prime} \mathrm{N}, 159^{\circ} 5^{\prime} \mathrm{E}$ yielded more Eocene pelagic chalks and volcanic breccias and basalts (Figure 24).

With a sense of frustration at not obtaining datable shallow-water material from the Wake guyots, we heeded our time schedule and responsibility to explore for DSDP sites and steamed north along $160^{\circ} \mathrm{E}$. However, Scripps Guyot was crossed at $24^{\circ} \mathrm{N}$, and we decided to attempt 


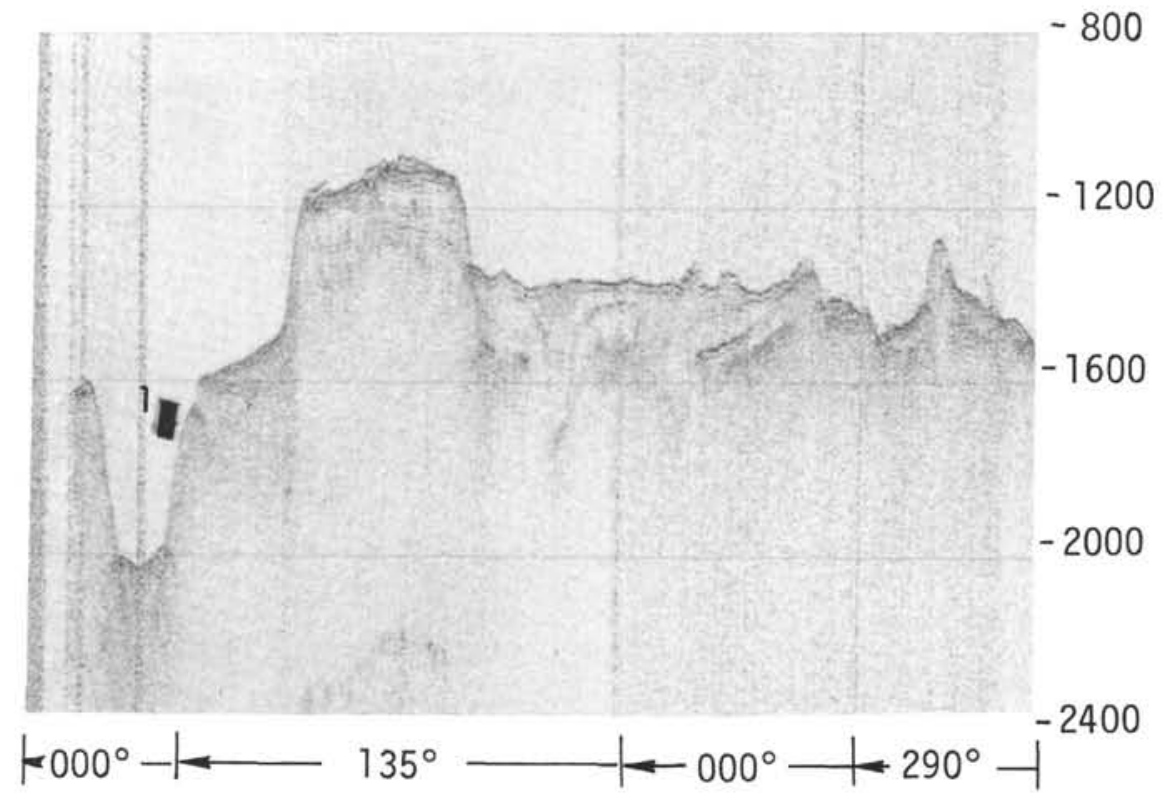

Figure 2. Seismic profile of Murray Guyot and escarpment at south margin of Mid-Pacific Mountains showing location where dredge haul obtained Pleistocene foraminiferal ooze and altered basalt. Horizontal lines on record represent seconds of total travel time.

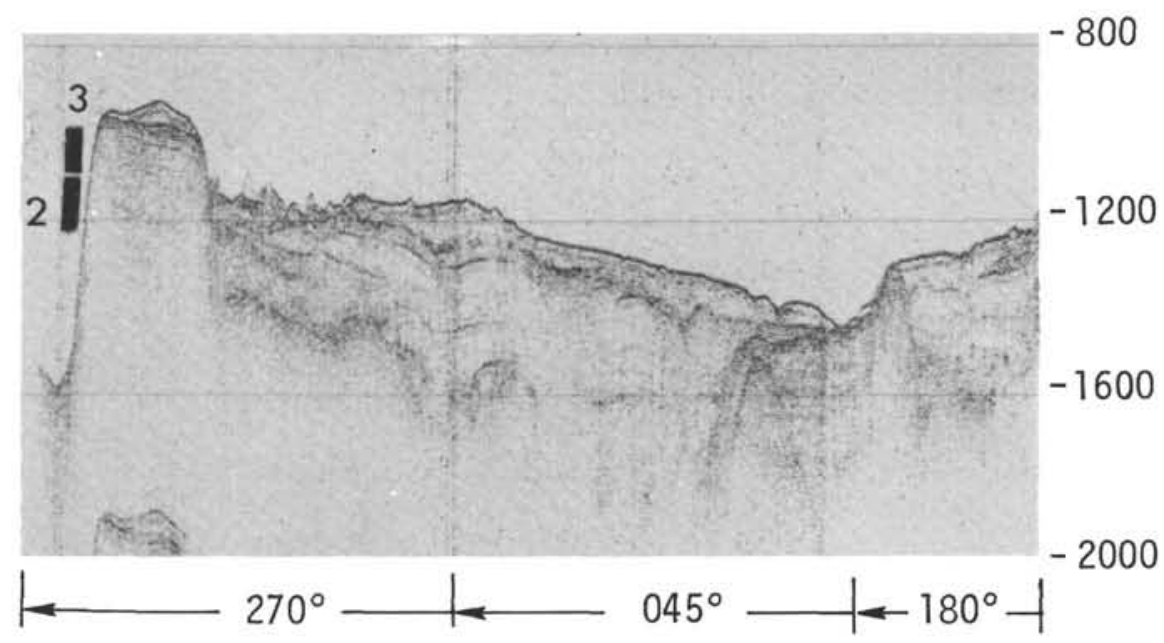

Figure 3. Dredge hauls 2 and 3 from the western flank of Renard Guyot shown in relationship to seismic reflection profile. Over $1 \mathrm{~km}$ of sediments have banked up against the eastern flank of the guyot while the western flank has remained bare of sediments. Dredge 2 obtained only Plio-Pleistocene foraminiferal ooze while dredge 3 also recovered lower middle Eocene foraminiferal chalk. The break in slope was not dredged. None of the middle Cretaceous material presumably present was recovered.

three more dredge hauls. They recovered material similar to that obtained on the other Wake area guyots (Figure 25). Dredge 27 contained a large quantity of manganese nodules and crusts. A number of the crusts consist of manganese nodules which had grown together to form a complete surface. It also contained some chalks which had ghosts of Cretaceous foraminifera.

After investigating a potential DSDP site southeast of the Shatsky Plateau, it was decided to explore some possible escarpments near the southern margin of the
Shatsky Plateau (Figure 26). After considerable difficulty in locating an attractive escarpment, a scarp of rather indifferent potential was dredged. The dredge did not hang up on the bottom and it was assumed that it had traversed a sediment-covered bottom. A small quantity of manganesecoated, altered basalt was recovered.

In the course of prospecting for suitable DSDP sites, we had occasion to pass close to Makarov Guyot. A survey'was conducted followed by two dredge hauls (Figures 27 and 28 ). Both hauls recovered shallow-water Cretaceous fossils, 


\section{CAPE JOHNSON}

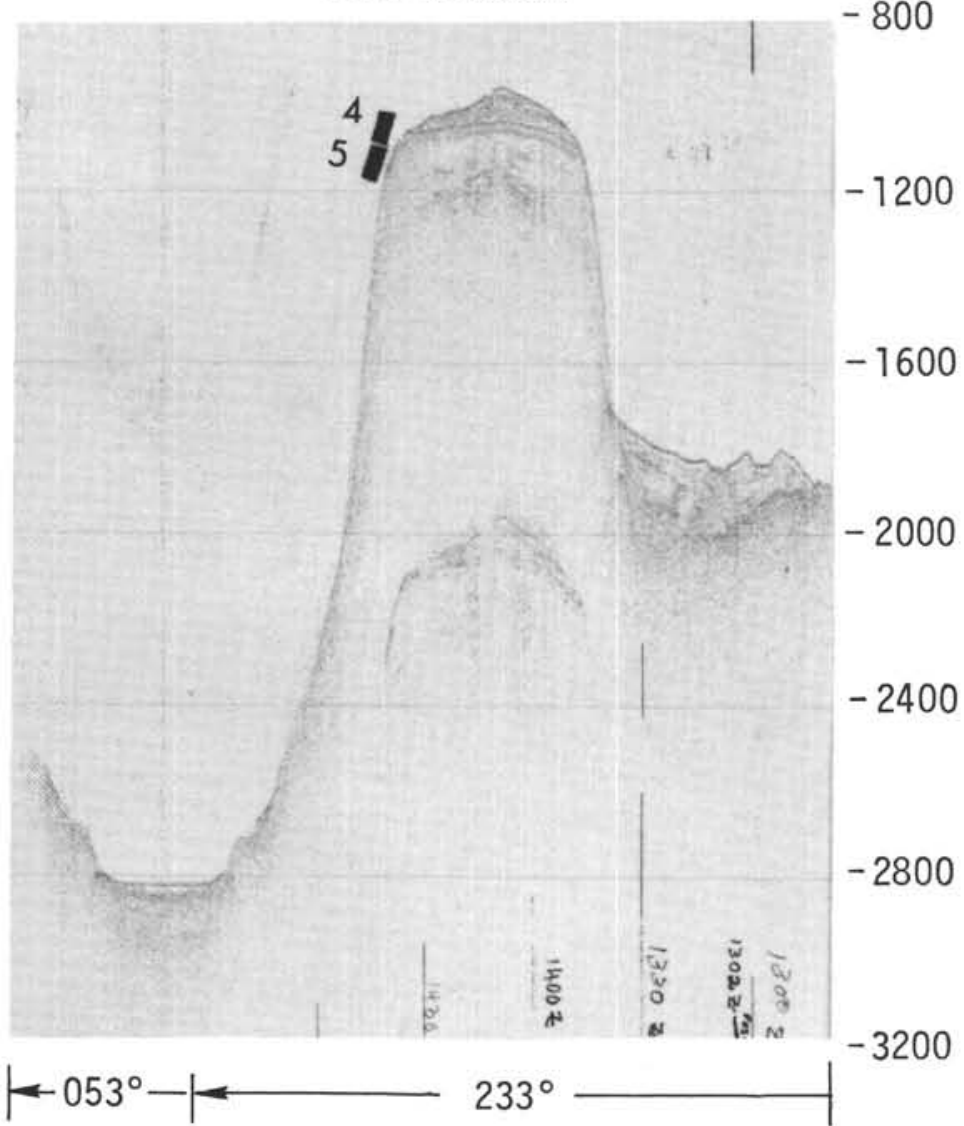

Figure 4. Dredge haul 4 near the break in slope of Cape Johnson Guyot recovered Pleistocene to Recent ooze while haul 5 also recovered manganese coated middle Eocene chalks and phosphorites. Two hauls reported by Hamilton (1956) obtained a few miles from dredge haul 5 obtained middle Cretaceous corals and rudistids.

but the fossils were more abundant in the shallowest haul (no. 30); the deeper haul (no. 29) recovered volcanic breccias establishing that a capping of reef material could not be more than a few hundred meters thick at most.

With cruise time running short, and still lacking attractive DSDP sites for Leg 20, we ran northwest to Isakov Seamount, made a brief summit investigation to establish that it was a guyot (Figure 29) and dredged (no. 31) Lower Cretaceous rudistid limestones from near the summit before running north and west to a group of poorly known seamounts which lie between the Japan Trench and the Shatsky Plateau. Several of these proved to be guyots and three were dredged (Figures 30,31). All revealed material similar to that found on Isakov Seamount. Maiko seamount, with a summit depth about $1 \mathrm{~km}$ deeper than the adjacent guyots, and lacking a flat top, was surveyed (Figures 32 and 33). Weathered basalts were dredged from the western flank. The final dredge hauls of the cruise (numbers 37, 38, and 39) were made on the rather large Seiko twin Guyot, which lies just east of the Japan Trench (Figure 34). Both hauls, nos. 37 and 39, recovered Cretaceous rudistids and phosphatized calcarenite. Dredge no. 38 at $34^{\circ} 10^{\prime} \mathrm{N}, 144^{\circ} 13^{\prime} \mathrm{E}$ recovered 10 pounds of sedimentary rock and a few manganese nodules and manganese crusts up to six inches thick.

\section{Age, Stratigraphy, and Petrography of Carbonates and Phosphorites (R. Catalano)}

Of the 33 successful dredge hauls on 16 guyots and other seamounts, 24 recovered carbonate and phosphate rocks, along with a variety of other rock types listed in Table 1 and as follows: (a) basalts and hyaloclastic matter, (b) carbonate oozes, Miocene or younger, (c) ironmanganese crusts, (d) brown and red pelagic clays, (e) radiolarian oozes, (f) bioclastic calcarenites and phosphorites of Cretaceous age, (g) phosphatized rudistid limestones of Cretaceous age, (h) pelagic chalks more or less phosphatized ranging in age from Cretaceous to Recent, and (i) breccias with various of the above components.

With the help of visual examination of whole samples, washed samples of microfossils, microscopic observation of thin sections, SEM observations and X-ray fluorescence and X-ray diffraction analysis (Figure 36), it was possible to distinguish the following main facies in the carbonate rocks: (a) nannoplankton-foraminiferal (pelagic) chalks and lutitic phosphorites of Cretaceous and Eocene age, and 


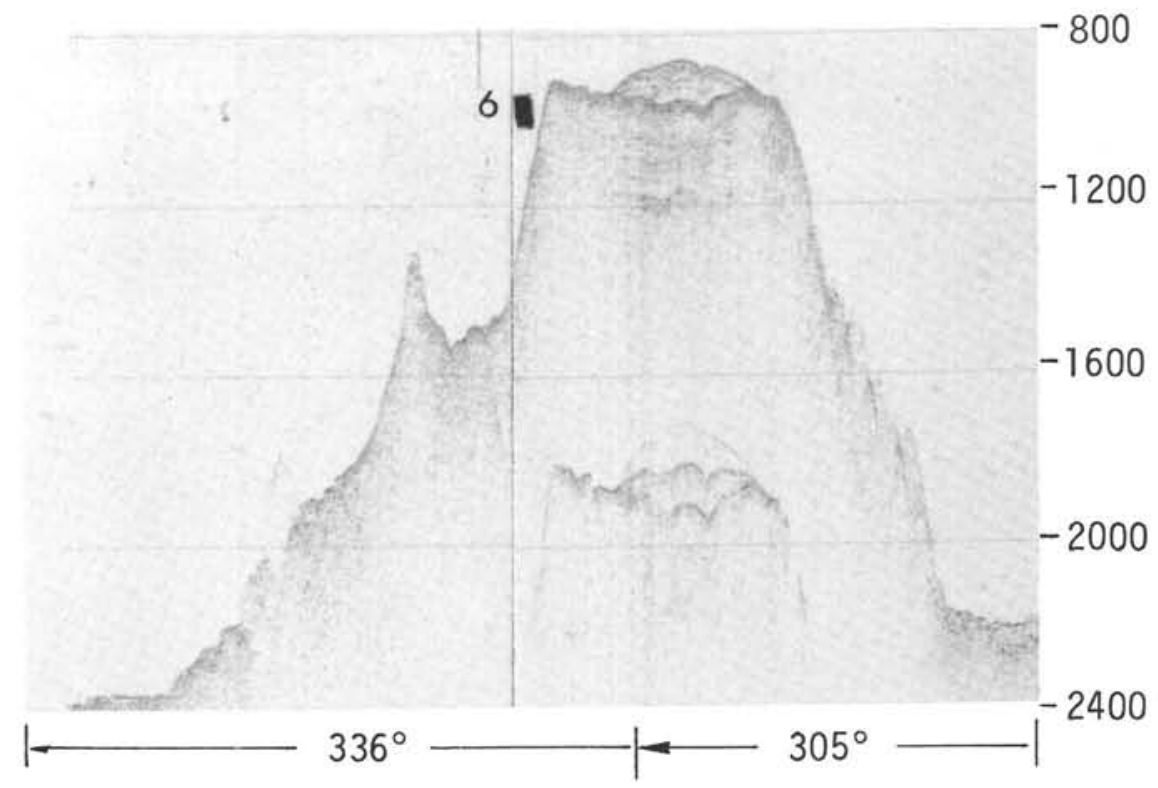

Figure 5. During Station 6 on the north flank of Navoceano Guyot the dredge became entangled with the bottom and was lost. Note the transparent sediment cap on the south central part of this large guyot and the reflections from beneath the cap suggestive of about $1 \mathrm{~km}$ of sediments lying in a caldera or lagoon.

(b) more or less phosphatized bioclastic calcarenites and rudistid limestones of Cretaceous age.

These two main facies are present both in the Mid-Pacific Mountains and in the Geisha guyots while sediments of the Wake seamounts are rocks of pelagic facies.

\section{Pelagic Chalk and Phosphorite Facies}

Rocks of this lithology were collected in 18 dredge hauls and occur on all but 2 of the guyots dredged (see Table 1). They are composed largely of nannofossils, planktonic and a few benthonic foraminifera and related fragments, euhedral unicrystalline grains of calcite (probably broken coccolith plates), and amorphous to weakly birefringent crystalline francolite grains. Porous and chalky, their color ranges from white through cream to brownish (according to the quantity of iron-manganese minerals). Burrowing is moderate; manganese coatings of various thickness are always present. In thin section they resemble lime mudstones foraminifera-coccolith lime mudstones and echinoid-debris wackestones.

The foraminiferal tests embedded in the fine matrix are generally complete but may also be represented by molds. Their chambers are empty or filled by a more or less weakly birefringent, crystalline cement (calcite and francolite). Some cavities show geopetal sediments. The X-ray diffraction analysis showed francolite, low-magnesium calcite, and traces of clay minerals. With the scanning electron microscope (SEM) they are seen to be porous, fine-grained aggregates of euhedral, tabular to hexagonal 1 to 5-micron size crystals of francolite with variable amounts of subrounded or broken calcite crystals coccolith plates, and some finer amorphous phosphate.

In this composite matrix, some foraminiferal tests are represented by molds with negative conservation of the structure (Plate 4, Figures 1,3). Their chambers are generally empty of sediment. The phosphatic pellicle, described later, preserves the fine detail of the test with pillars instead of the original pores. In some other samples, the chambers are filled in their lower parts by calcite cement (drusy calcite) which appears as stubby rhombohedra in radial aggregates. Iron and manganese oxides often occur as microcrystalline intergrowths with phosphatic minerals. These oxides appear in thin section as layered encrustations.

\section{Fossils and Age}

The presence of planktonic foraminifera of the families Globotruncanidae, Globorotaliidae, Globigerinidae, and Hantkeninidae in these rocks made it possible to employ these most useful fossils for dating of the rocks. Despite their poorly preserved state, it was possible to determine three main assemblages.

Assemblage 1: The Eocene is characterized by the index fossils Globorotalia aragonensis, Acarinina bullbrooki, A. pseudtopilensis, A. quetra A. soldadoensis, Truncorotaloides topilensis, Globorotalia centralis, G. cerroazulensis, and Hantkenina spp.

Assemblage 2: The Senonian-Maastrichtian is identified by the index fossils Globotruncana cf. G. lapparenti, Globotruncana cf. G. tricarinata, Globotruncana cf. G. contusa and Globotruncana cf. G. arca.

Assemblage 3: The upper Albian-lower Turonian is characterized by the index fossils Ticinella roberti, Clavihedbergella cf. C. simplex, Rotalipora cf. C. cushmani, Praeglobotruncana cf. $P$. helvetica Rotalipora cf. $R$. greenhornensis Hedbergella cf. $H$. postdownensis, and Heteroelix cf. H. globulosa. The relative age of the various samples was determined by considering the oldest assemblage present in each heterogenous assemblage. 


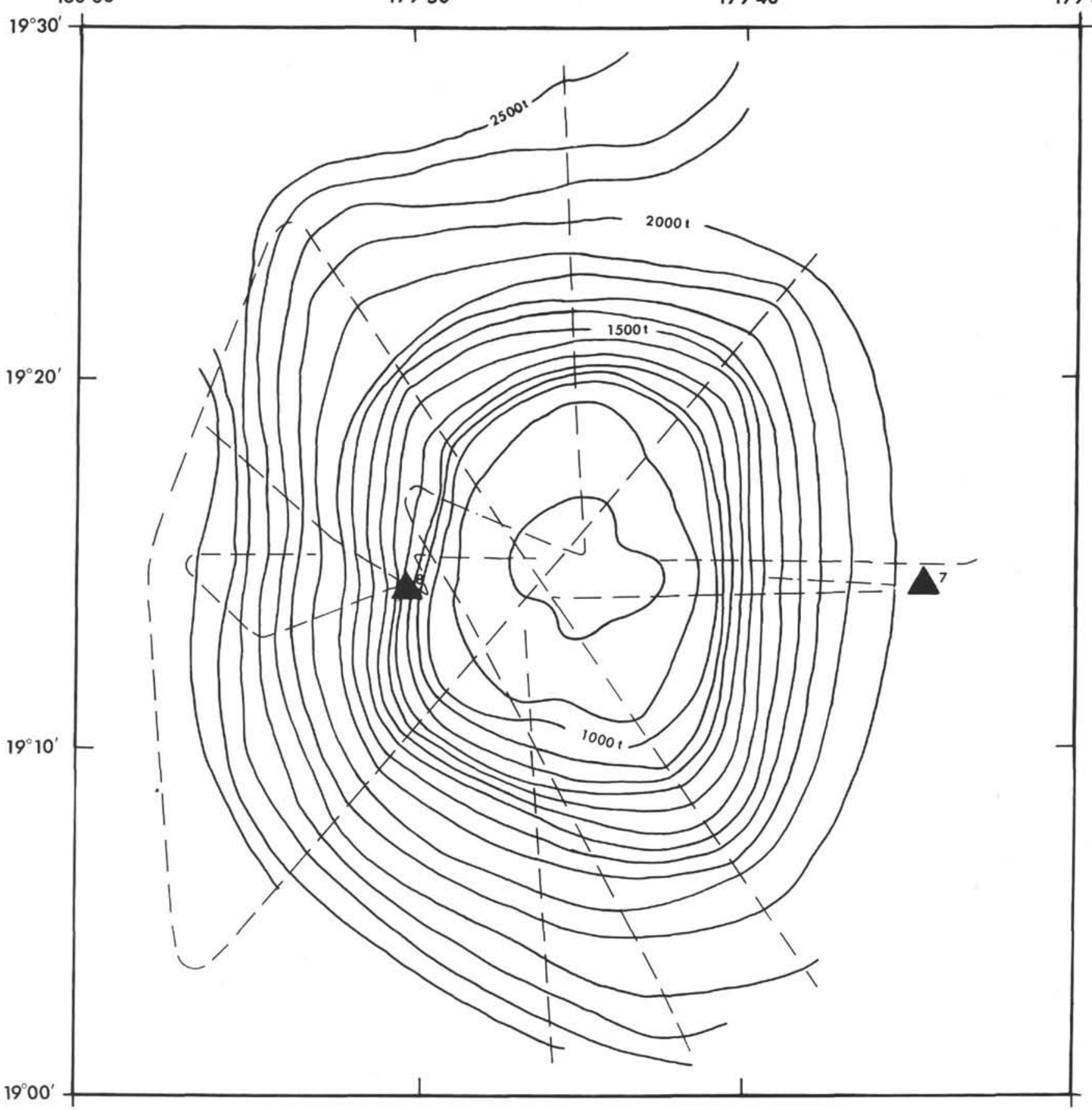

Figure 6. Bathymetric sketch of Shepard Guyot showing location of dredge stations 7 and 8. Dredge 7 from the east flank of the guyot obtained, apparently as talus, Lower (?) Cretaceous red algae, corals, and molluscs in porous limestones together with basalt and manganese coated phosphatized chalk of Cenomanian-Turonian age.

\section{Environment and Paragenetic Sequence}

The obvious components, generally fine-grained character, slow rates of deposition, and lack of structures suggest that the chalks were deposited in a deep pelagic environment on the top of the seamounts, where they later underwent submarine lithification. Submarine cementation has been reported in various deep-sea areas (Friedman, 1964, Milliman, 1966, Fischer and Garrison, 1971).
Milliman (1966) suggests that at a slow rate of accumulation (or during nondepositional phases) magnesium calcite can lithify carbonate sediments under normal oceanic conditions.

In the lithified chalks from the Pacific guyots calcite was repeatedly replaced, volume by volume, by intimately mixed carbonate apatite and iron-manganese. The chalks were subsequently burrowed and the pores filled with 


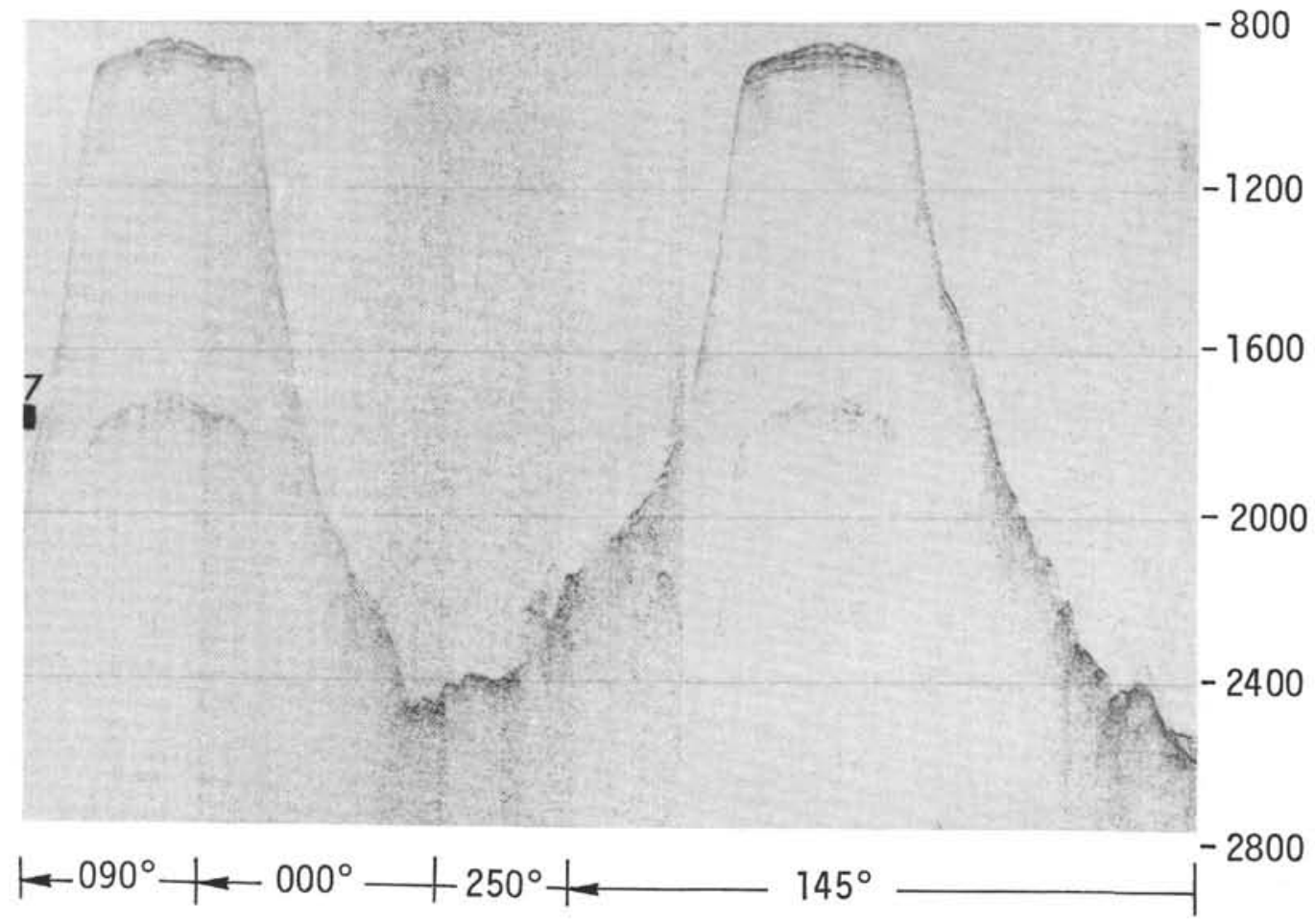

Figure 7. Two seismic reflection profiles of Shepard Guyot showing the location of dredge 7.

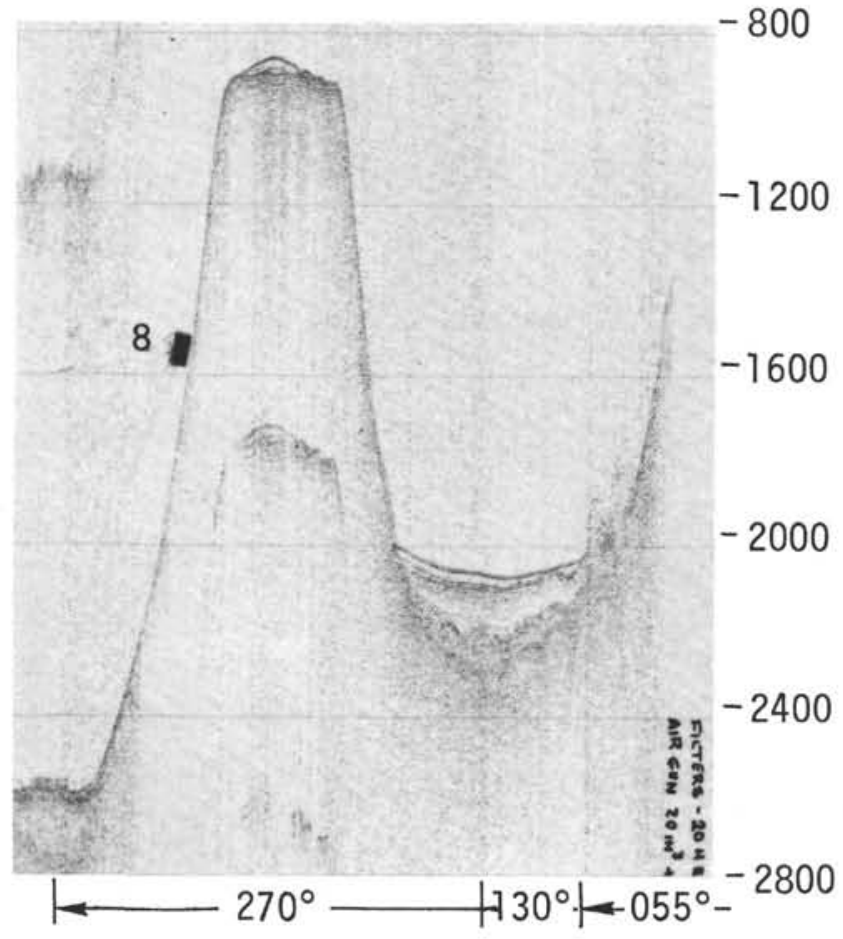

Figure 8. Seismic reflection profile of Shepard Guyot showing location of unsuccessful dredge station 8 on west flank of seamount.

micritic sediment bearing unphosphatized recent planktonic foraminifera and coccoliths.

\section{Bioclastic Calcarenites and Rudistid Limestones}

Bioclastic calcarenites dredged from most of the seamounts in association with phosphatized equivalents (bioclastic and rudistid phosphorites) appear as highly porous calcarenites or coquina limestones, white to cream in color, with thin iron-manganese crusts. They are composed of skeletal grains cemented by calcite or occasionally embedded in a very fine calcite matrix. The skeletal grains, ranging in size between $0.1 \mathrm{~cm}$ and $3 \mathrm{~cm}$, are well-sorted and have well-rounded to subangular shapes. An even cement fringe, in some cases syntaxial and other cases not, is seen around the skeletal grains. Most of them are enclosed in a micritic envelope. Coated grains and peloids are rarely present and are contained in a fine-grained matrix. In thin section these rocks are seen as mollusk-lime packstone or skeletal-lime grainstone or echinoid-plate wackestone. The X-ray diffraction analysis of these rocks show low-magnesium calcite as the predominant mineral component. Some of these calcarenites are partially or wholly phosphatized, showing the original calcite cement and/or matrix also phosphatized together with the grains. X-ray analyses of these rocks show a large amount of francolite with low-magnesium calcite.

The rudistid limestones are predominantly composed of partially phosphatized caprinids, solitary or hermatypic corals, mollusks, and large echinoid spines. In thin section these appear as very finely phosphatized fossils, with weakly birefringent cryptocrystalline to amorphous phosphate. Molds of dissolved laminae of the rudistids have been filled with Globotruncana (Post-Cenomanian) and lime mud, and have subsequently been phosphatized.

\section{Fossils and Age}

Rudistids, corals, mollusks and their fragments, bryozoa, coralline algae, stromatoporoids, echinoids, otoliths, conodont fragments, arenaceous foraminifera, and Orbitolina spp. and other benthonic foraminifera are preserved as 


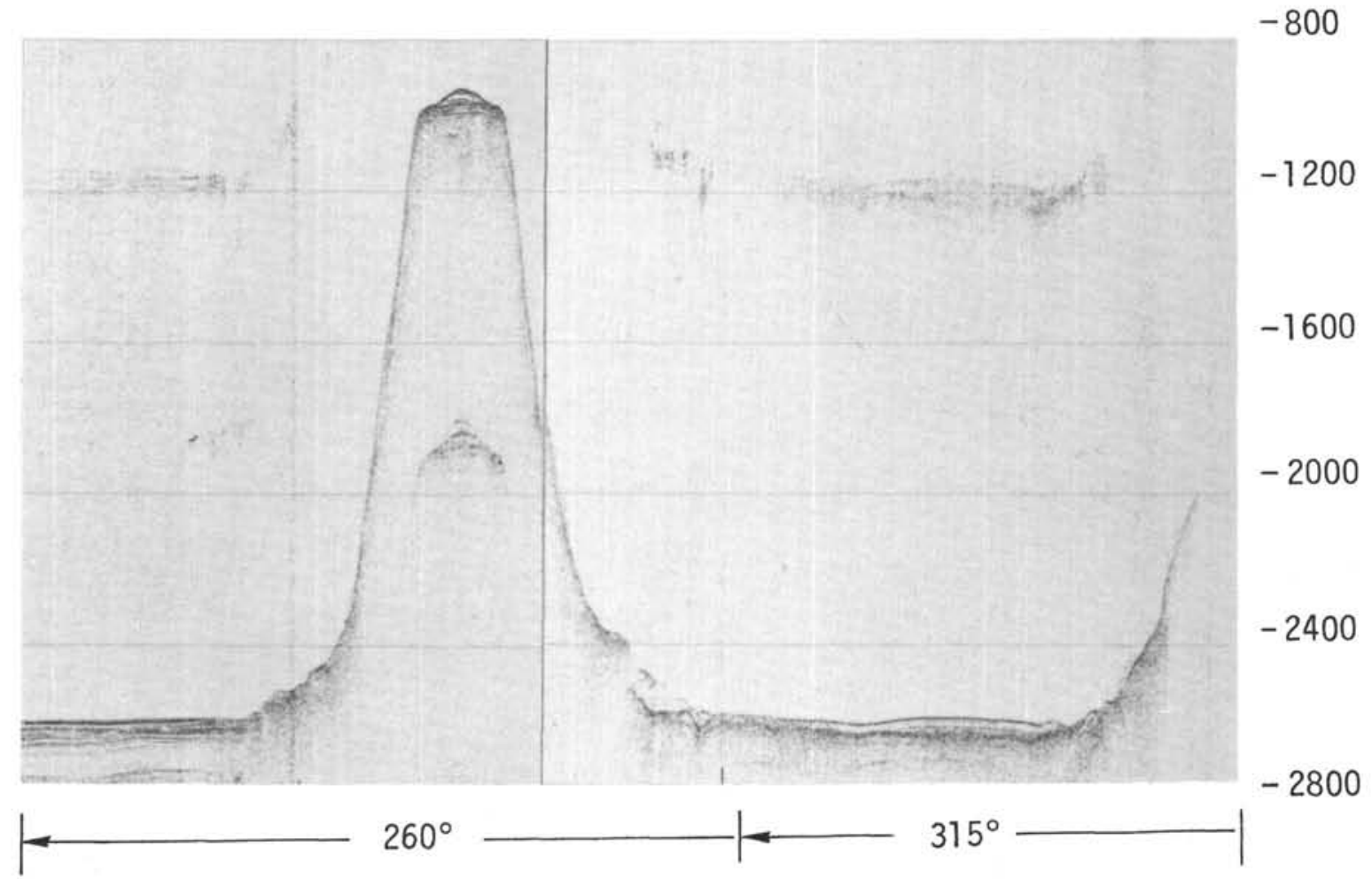

Figure 9. Seismic reflection profile of Revelle Guyot. Note the transparent sediment cap and the thick sequence of ponded sediment in the surrounding basin.

molds and casts as well as unaltered. The age of these rocks was determined on the basis of the caprinid assemblage as Albian to Turonian (?). An Albian to Cenomanian date was indicated by the index fossil Orbitolina spp. The planktonic foraminiferal assemblage, which fills the rudistid walls, indicates an age between late Cenomanian and Senonian.

\section{Phosphatization}

Phosphatization has occurred on all the guyots where indurated carbonate sediments were dredged. The phosphatization seems to involve all types of carbonates, reef-rudistid limestones, and breccias. Phosphatization is commonly patchy and diffuse. The phosphorites are porous with a matte texture, lacking the more usual dense texture; they range in color from cream to tan and brown, and locally to pink. The iron and manganese oxides are commonly associated and stain the rocks dark brown to black.

X-ray diffraction studies by Hermelin and Catalano (Figure 36) show that these phosphorites are composed mainly of either francolite of an almost uniform lattice structure (McConnel, 1938) and crystal habit, or of a mixture of calcite and francolite. Precise determinations of the francolite were made by using X-ray diffractometer data refined by the least mean square method.

The X-ray data show (a) that the difference between individual values from our diverse seamount rocks is quite small; and (b) that there is a good agreement with the lattice parameters calculated from previously published X-ray data from central Pacific seamounts (Hamilton, 1956) and Caribbean seamounts (Marlowe, 1971). A plot of the values of $a$ and $c$ for 13 of the western Pacific seamount phosphorites is shown in Figure 36. Each of these values is a weighted mean of the results of four X-ray runs of the same sample. In Figure 36, these values are compared with published X-ray data on phosphorites from Sylvania, Johnson, and Horizon guyots in the central Pacific (Hamilton and Rex, 1959) and from the Aves Ridge in the Caribbean Sea (Marlowe, 1971; Hermelin and Catalano, unpublished data).

The great bulk of the phosphatic minerals appear to be cryptocrystalline or amorphous (collophane) in thin section. However, some sections show small amounts of optically resolved and birefringent phosphate, the latter in the form of geopetal fillings, fibrous cavity linings, fish teeth, and subhedral to anhedral unicrystalline grains. Observations with the electron microscope reveal that most of the phosphorite is a porous, loosely packed aggregate of euhedral, hexagonal, tabular, mostly equigranular crystals of francolite. These show a size range from 0.5 to 4 microns. They constitute the wall structure of foraminifera, mollusks, and other skeletal remains. SEM observations of some samples show another phase in addition to the comparatively coarse francolite. In these samples, surfaces of foraminiferal tests appear to have been replaced by (or may be encrusted by) a fine-grained, possibly amorphous phosphate which forms a delicate, clearly visible pellicle where the skeletal calcite has dissolved. Thus the tests are preserved in good detail. X-ray fluorescence analysis suggests that such pellicles have a phosphorous content in excess of that of francolite. The same determinations suggest a strong association in the occurrence of manganese and iron with phosphate.

The mode of origin of the phosphate found in phosphorites and other sedimentary phosphatic rocks has, in the past, been interpreted according to two diverse 


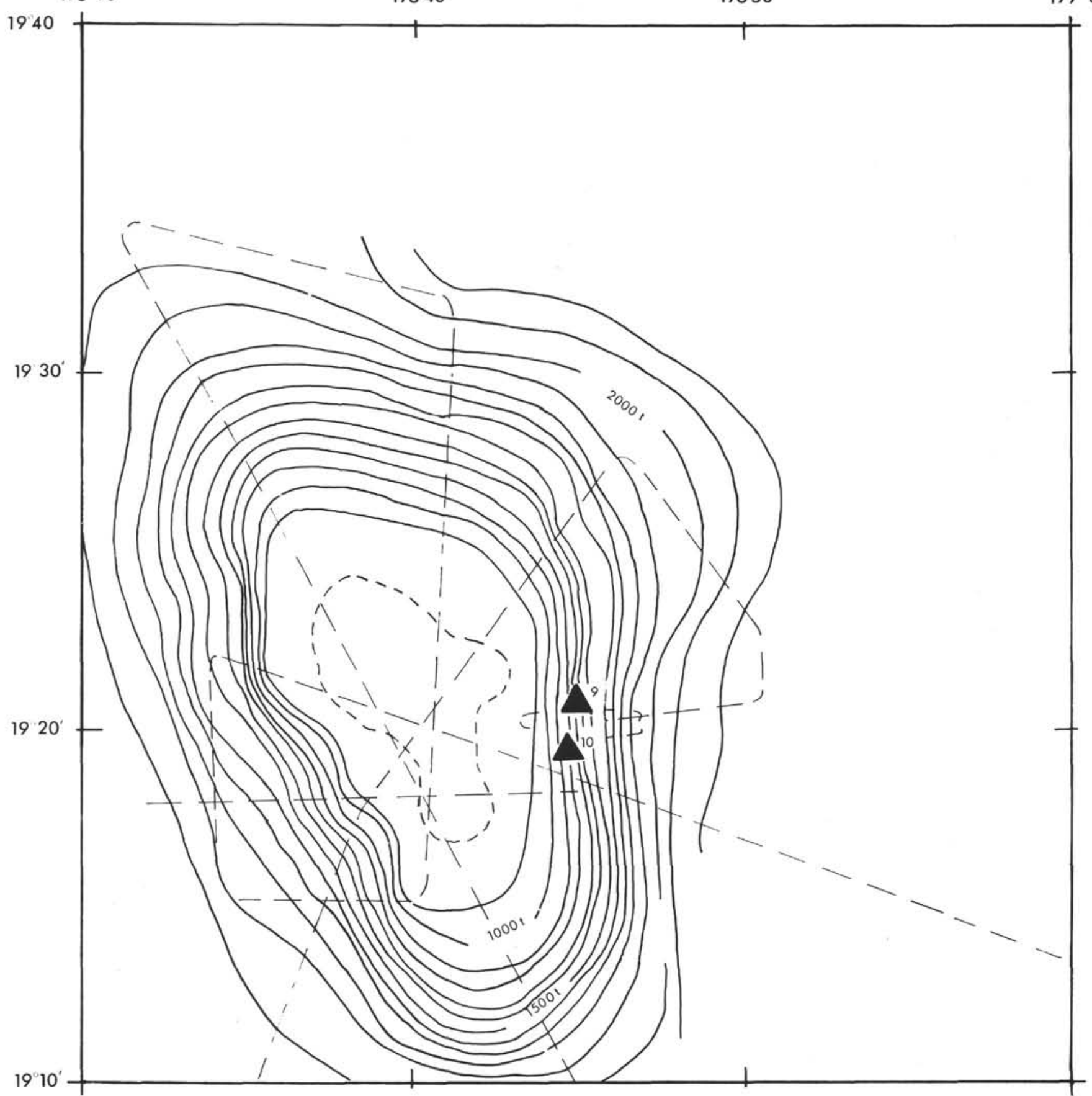

Figure 10. Bathymetric sketch of Jacqueline Guyot showing location of dredge hauls 9 and 10. The deeper haul (9) obtained basalt while the shallower one (10) recovered Lower Cretaceous reef material.

theories. The first invokes direct precipitation from solutions saturated with respect to phosphate (Kazakov, 1937, Dietz et al., 1942). The second theory requires a replacement process whereby preexisting calcite is converted to carbonate-apatite as a result of exposure to phosphate-rich solutions (Ames, 1959, Marlowe, 1971). Our rocks show a pattern of replacement of carbonate by francolite. The nature of this replacement is variable. In the Cretaceous shallow-water rocks, the fossils have generally been replaced by francolite with retention of some microstructure. The grid structure of some mollusk (rudistid) shell walls, apparently complete at high magnification, is in fact composed of an aggregate of oneto two-micron hexagonal crystals of francolite. The same crystals have replaced the calcite cement binding the bioclasts, with pseudomorphous retention of the scalenohedra. In the Cretaceous and Eocene chalks, the fine-grained, coccolith-rich matrix is seen to be replaced by a loosely packed aggregate of hexagonal francolite crystals (Plate 4, Figures 2, 4, 6). The calcite of the foraminiferal tests appears to be generally dissolved in the more completely phosphatized rocks, leaving conspicuous molds 




Figure 11. Seismic reflection profiles of Jacqueline Guyot showing location of dredge hauls 9 and 10. The transparent sediment cap of Jacqueline Guyot is significantly thinner than observed on the guyots to the east and the deeper beds are thinner or were not penetrated.

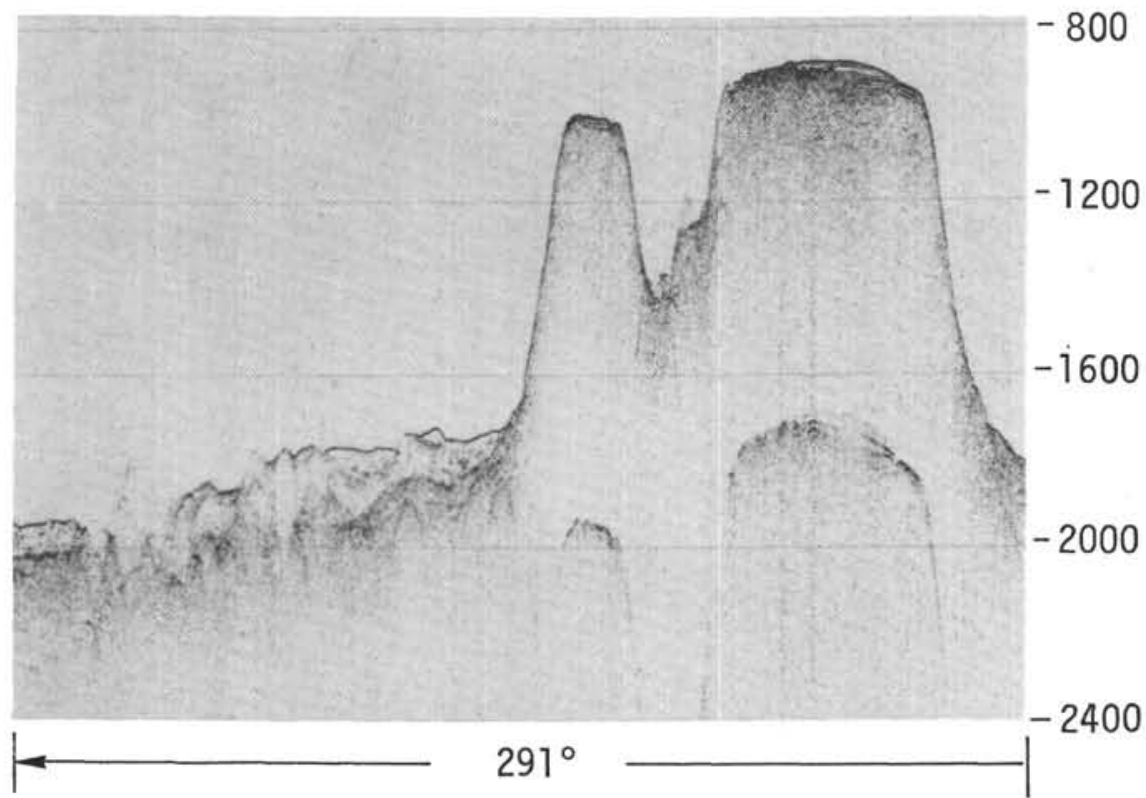

Figure 12. Seismic reflection record of Stetson Guyot and Hill Guyot. Note the complex apparently distributed stratification of sediments to the west of Hill Guyot. 


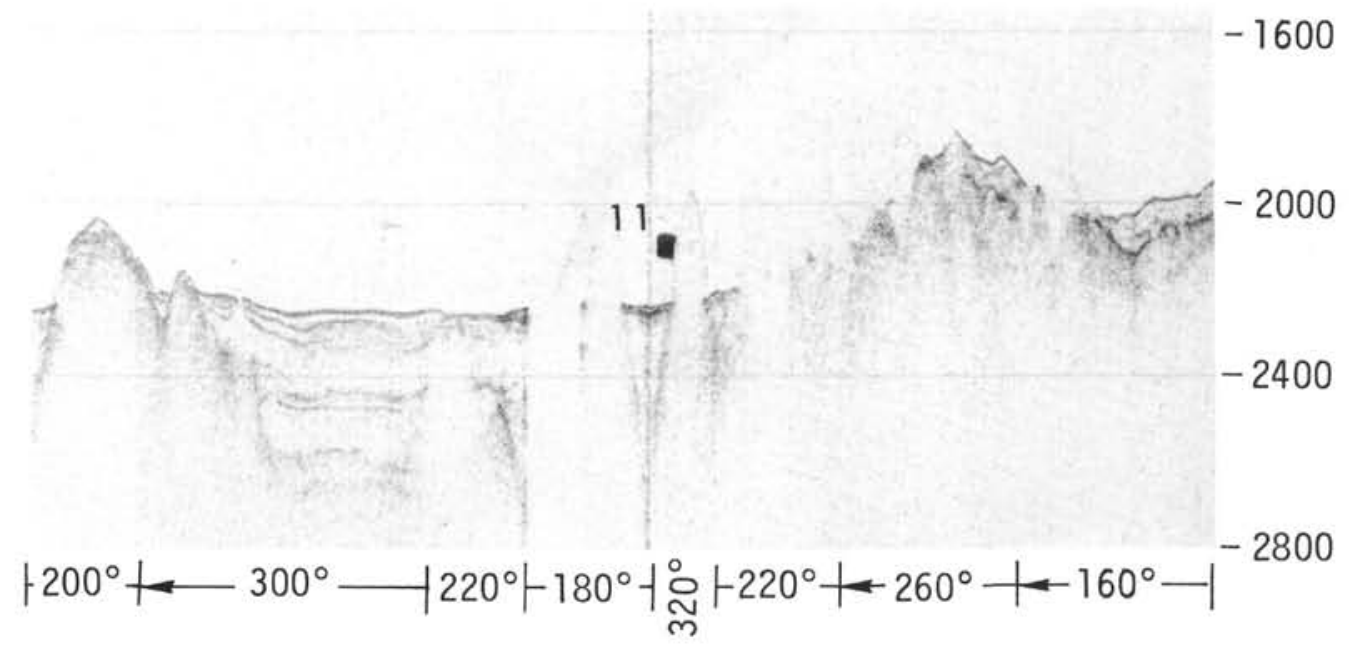

Figure 13. Location of dredge 11 on a deep pinnacle. Only a few chips of manganese encrusted basalt were obtained. The pinnacle apparently lies along a ENE-WSW trend. The extremely steep sides give a poor reflection and suggest rock outcrops, but its small size makes it a poor target for the dredge.

partially filled by crystalline phosphate. In other specimens, the replacement has resulted in massive amorphous collophane showing little original texture.

\section{Carbonate Early Diagenesis}

Paleoecological and petrographic study of the bioclastic calcarenites demonstrates that early diagenesis took place in a shallow-water environment influenced by breaking waves and subaerial emergence.

The petrography of these rocks displays the following peculiar patterns:

1) Well-rounded and well-sorted grains (surf zone).

2) Richness and stability of micrite envelopes (Bathurst, 1966).

3) Two types of porosity: (a) Primary, intergranular porosity, and (b) secondary intramicrite envelope porosity.

A sparry calcite cement occludes wholly or partly both types of pores. This cement varies from a simple fringe to a complete pore filling. In some rocks the porosity remains high with only a slight development of cement fringes on the thin delicate micrite envelopes (about 20-40 $\mu$ ). Tabular masses of micrite, possibly representing filled algal bores or calcitized endolithic algae (Schroeder, 1972) occur within some otherwise empty envelopes.

Ghosts of a radial-fibrous uniform fringe (phreatic?) could have originally been aragonite or high magnesium calcite. According to the criteria offered by Bathurst (1964, 1971), Land (1970), and others for Recent and Pleistocene rocks, the diagenesis of our biocalcarenites appear to have taken place in meteoric-phreatic and marine-phreatic zones. In fact some of these rocks show a cement, uniformly initiated at the grain surface with small crystals, followed by large cement crystals, (about $300 \mu$ ) indicating a phreatic-meteoric diagenesis. Other grains show an even rind of radial-fibrous or acicular calcite cement around the grains (ranging between $60 \mu$ and $80 \mu$ ), followed by coarse-grained cement $(70 \mu$ to $250 \mu)$. These two generations of cement indicate that the rocks first formed in a marine-phreatic zone and later passed into a meteoricphreatic zone (Land, 1970). The fabric evolution of these biocalcarenites could have been as follows:

1) Stage I: Thorough rounding and sorting of unconsolidated lime sand, composed mainly of a mixture of bioclasts, in the surf zone.

2) Stage II: Invasion of grains by micrite envelopes.

3) Stage III: Appearance of low-magnesium calcite cement as uniform fringe on grains.

4) Stage IV: Dissolution-precipitation-dissolution of the unstable minerals partially balanced by precipitation of calcite in the two types of primary and secondary pores.

5) Stage V: In some cases, subsequent filling of pores with lime mud or with iron-manganese deposits.

6) Stage VI: Phosphatization (when it occurred).

\section{Summary}

Shallow- and deep-water carbonates and phosphorites of Cretaceous and Eocene age were dredged on 16 guyots in the northwest Pacific. The guyots of the Mid-Pacific Mountains and the Geisha guyots are capped by shallow-water rocks (Lower Cretaceous rudistid limestones) overlain by pelagic deep-water rocks (nannofossilglobigerina chalks of upper Cretaceous and Eocene age). The Wake seamount group yielded only Eocene pelagic chalks. Most of the shallow- and deep-water deposits are partly or wholly phosphatized. The deep-water rocks appear as porous lutitic limestones and chalks composed largely of the remains of pelagic organisms. These rocks are thought to have been deposited in a deep, pelagic environment at the top of the seamounts and lithified in an area of slow accumulation where magnesium calcite was being precipitated. The shallow-water rocks appear as highly porous bioclastic calcarenites and reef limestones. Their deposition and early diagenesis took place in a shallow-water environment and was influenced by breaking waves and subaerial emergence. The petrographic studies offer some criteria for distinguishing marine from meteoric cements and for establishing the fabric evolution. 


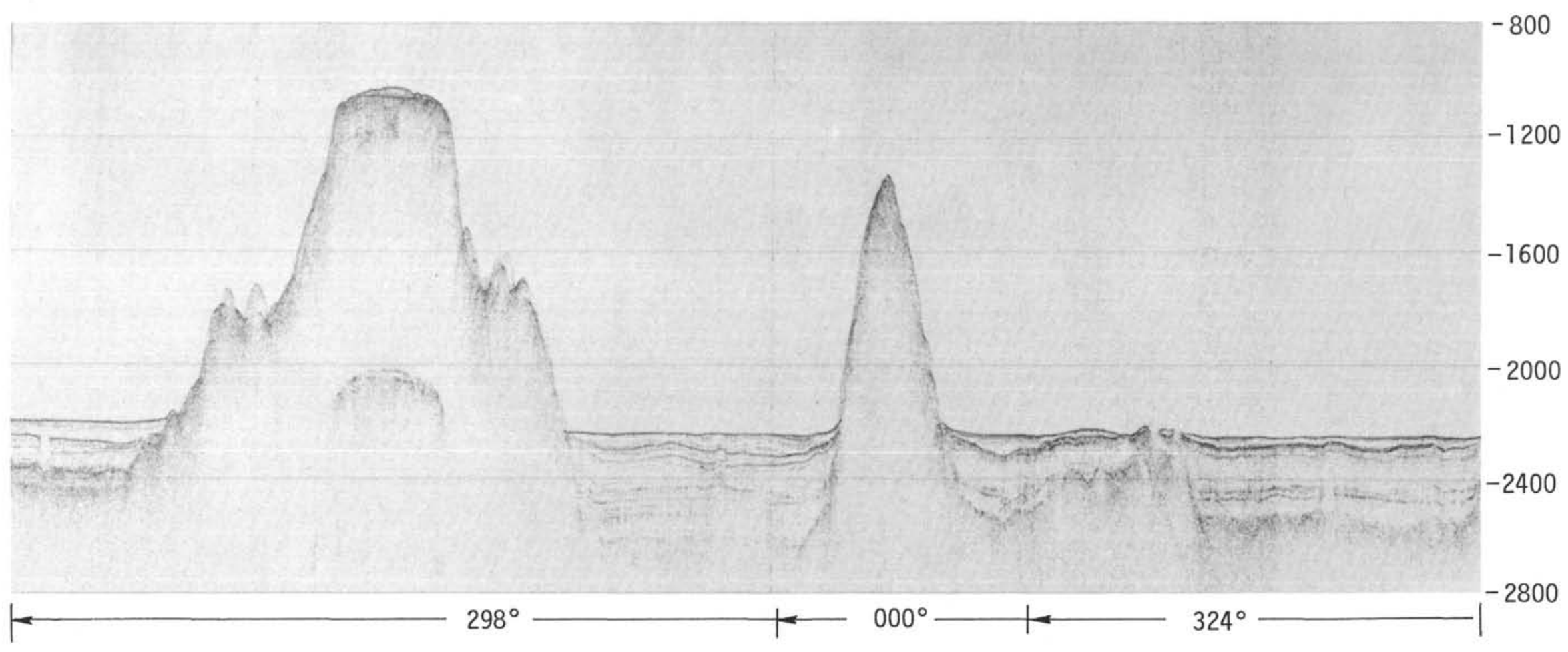

Figure 14. Ewing Guyot in the western Mid-Pacific Mountains is surrounded by a thick sequence of ponded sediments more than $1 \mathrm{~km}$ thick. A rather full history of the area could be expected from a hole drilled in this area. 


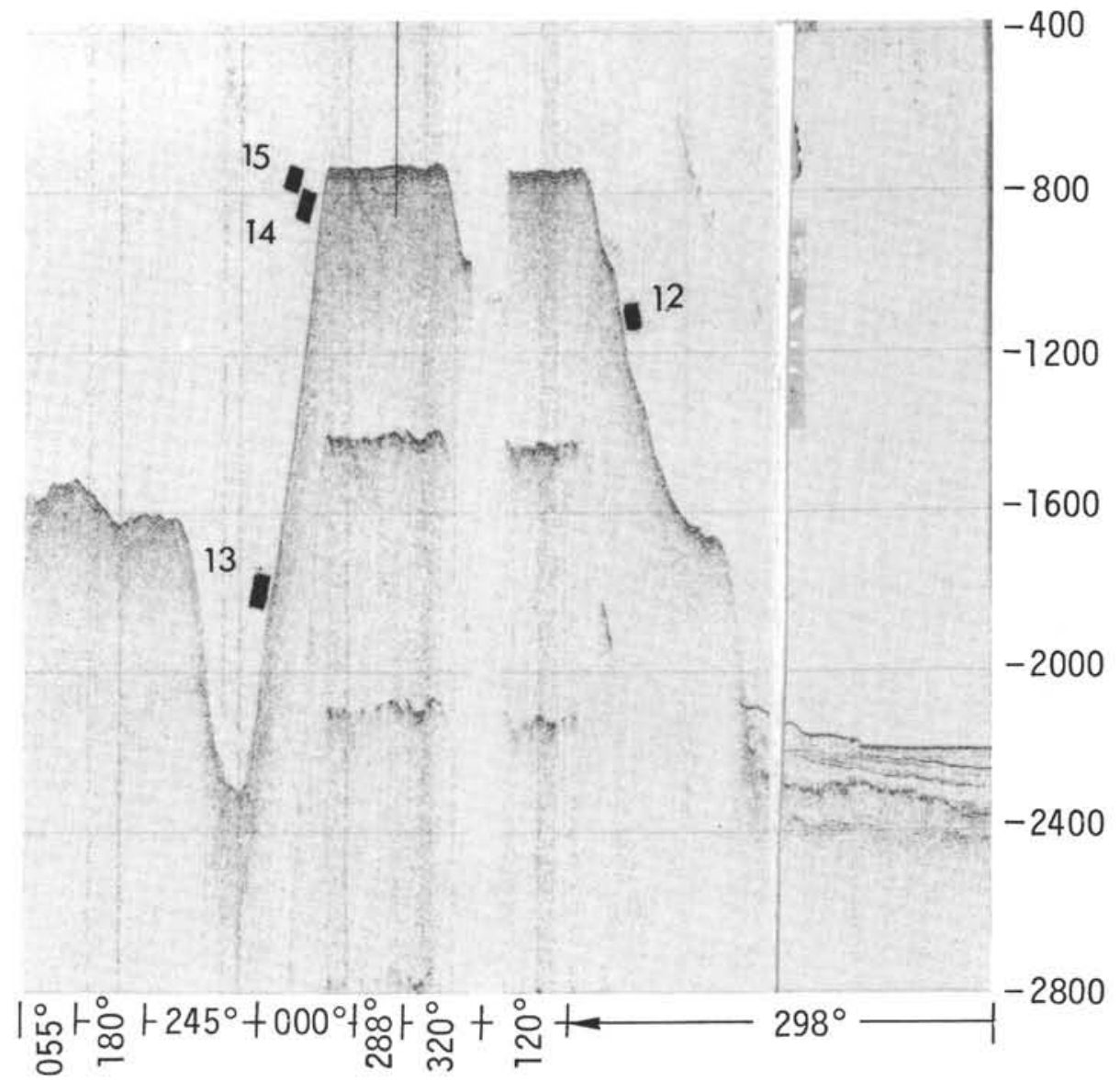

Figure 15. Dredge hauls 12 to 15 were obtained on the flanks of Menard Guyot one of the western-most of the Mid-Pacific Mountains. Dredge 12 recovered, apparently as talus, mid-Cretaceous reef material as well as manganese coated and phosphatized chalk of Cenomanian-Turonian age. Dredge 13 obtained altered basalts and holoclastics from deep on the north flank of Menard Guyot. Dredge 14 and 15 dredged apparently in situ stromatoporoids and red algae of Upper Cretaceous age.

Phosphatization has occurred in both types of rock as replacement of the original calcareous texture by francolite (carbonate-apatite) from seawater, in the presence of upwelling phosphatic currents (Ames, 1959; Marlowe, 1971). The nature of this replacement is variable. In the Cretaceous shoal-water carbonates, the fossils appear replaced by hexagonal francolite crystals with retention of some microstructures (grid structure and pseudomorphous scalenohedra). In the chalks, the fine-grained, coccolith and foraminifera-rich matrix appears either replaced by a loosely packed aggregate of hexagonal francolite crystals or by massive, amorphous collophane (generally altering the original texture). Iron and manganese oxides occur as an intimate intergrowth with phosphate (Arrhenius, 1963). On the basis of paleoecological and petrographic studies of these rocks, it has been possible to establish the following Cretaceous and Eocene sedimentary history for the seamounts of the northwest Pacific.

During the Lower Cretaceous a shoal-water depositional environment (reef environment) covered the partially emergent tops of the volcanoes. Synsedimentary early diagenesis affected the bioclastic calcarenites and reefrudistid limestones. Later, a recurrent calcite replacement by francolite (phosphatization) occurred in the presence of upwelling phosphate-rich currents. During Cenomanian-
Turonian time a synchronous extermination of the reef fauna, evidently due to a eustatic rise of sea level, put an end to shallow-water deposition. After the eustatic rise, the guyots became sites of the deposition of foraminiferal ooze; open- and deep-water deposition started at this moment, yielding pelagic sediments. An extended period of nondeposition (or slow accumulation) followed. Environmental factors favored submarine lithification on the top of the seamounts and subsequent recurrent phosphatization of the pelagic sediments.

\section{Petrography of Volcanic Rocks (J. Natland)}

\section{Introduction}

This section presents petrographic deşcriptions of the volcanic rocks dredged during ARIES Leg V and of volcanic rocks from Horizon Guyot and Necker Ridge. Horizon Guyot has been dredged four times (twice on MID-PAC Expedition, 1949; once on STYX Expedition, 1968; and once on SEVEN-TOW Expedition, 1970). Visual descriptions of the dredge hauls from Horizon Guyot were given by Hamilton (1956) and Lonsdale and others (1972). Necker Ridge was also dredged on Expedition SEVENTOW. In all, petrographic data are given for three guyots 


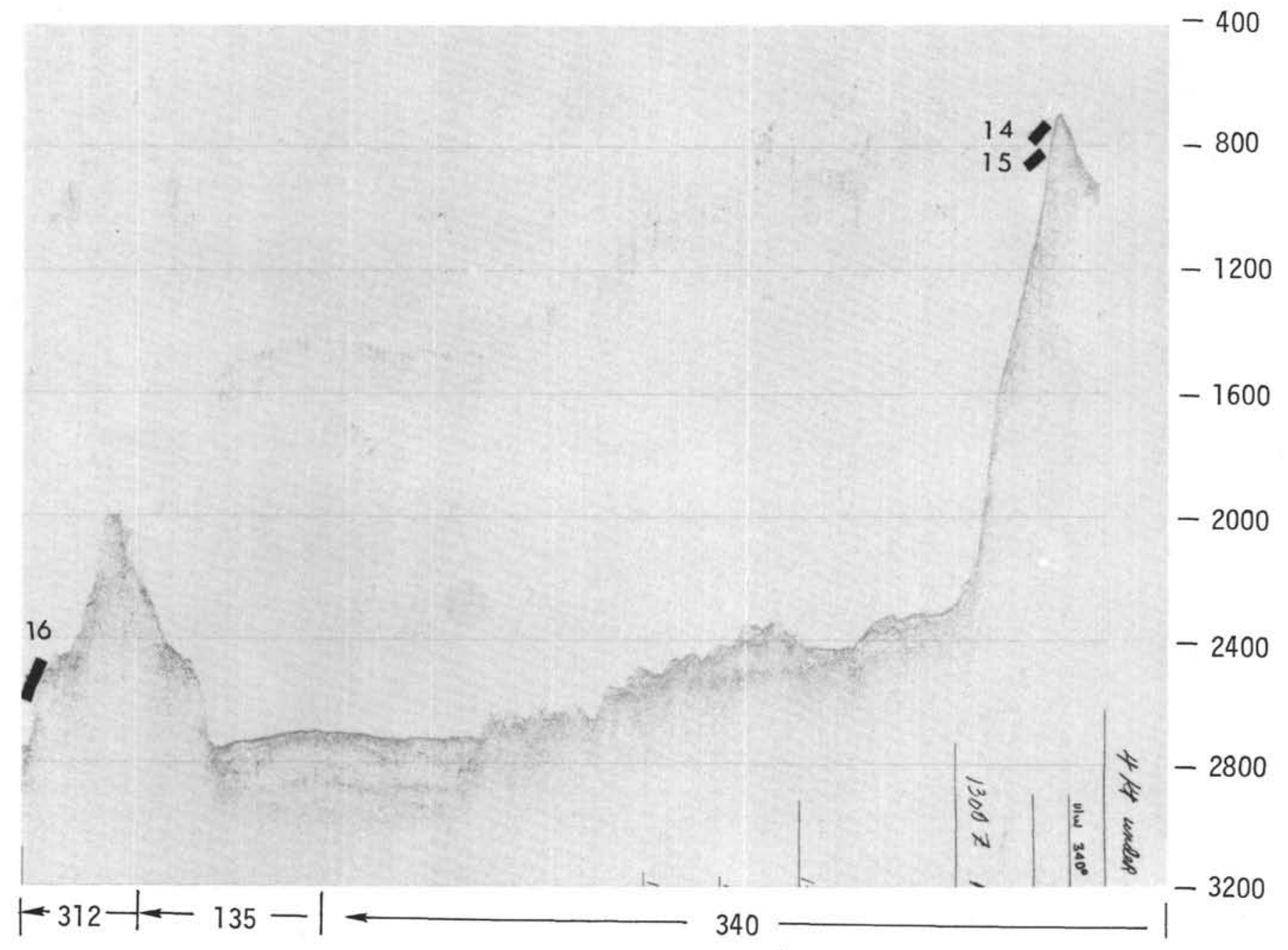

Figure 16. Three seismic reflection profiles across the boundary between the Mid-Pacific Mountain area and the deep northwest Pacific basin. The two crossing at the left appeared to offer an opportunity for dredging. Dredge haul 16 obtained volcanic ash and basalt fragments, but the smooth action of the dredge indicated a fairly complete sediment cover.

and two ridges in the Mid-Pacific Mountains, four guyots in the Wake group, one ridge south of Shatsky Plateau, and three guyots and a seamount in the Geisha seamounts. The petrography of the dredged volcanic rocks suggests the existence of several petrographic provinces among the guyots of the western Pacific Ocean.

\section{Petrography of Volcanic Rocks from the Mid-Pacific Mountains}

Volcanic rocks were studied from dredge sites on Necker Ridge, Horizon Guyot, Murray Guyot, Shepard Guyot, and a ridge west of Jacqueline Guyot, all from the complex of ridges and seamounts west of Hawaii called the Mid-Pacific Mountains. Apart from the rocks of Necker Ridge and Shepard Guyot, all are either basalts or intermediate composition rocks, probably belonging to tholeiitic differentiation series. They are characterized by phenocrysts of both olivine and plagioclase, lesser augite phenocrysts, and tiny groundmass crystallites of pigeonite. Tholeiitic basalts of similar mineralogy were described by Bass and others (1973) from DSDP Site 171 on Horizon Guyot, and hypersthene-bearing basaltic sandstones dredged from Cape Johnson Guyot were mentioned by Hamilton (1956). The available chemical and mineralogic evidence, particularly the prevalence of hypersthene and pigeonite, minerals which typify tholeiitic and not alkalic oceanic volcanic suites (Macdonald and Katsura, 1964), indicate a largely tholeiitic province in the Mid-Pacific Mountains. The rocks from Necker Ridge, however, appear to belong to an alkalic suite. Fossil and radiometric evidence to be presented indicate that they are considerably younger than rocks from Cretaceous guyots of the Mid-Pacific Mountains.

\section{Horizon Ridge (Guyot)}

Horizon Guyot (Figure 1) is actually two separate platforms forming an elongate ridge over $300 \mathrm{~km}$ long and as wide as $70 \mathrm{~km}$ (Hamilton, 1956; Lonsdale, et al., 1972). Each platform was dredged twice at or above the main break in slope. The main break in slope is the usually sharp transition between the nearly level top of a guyot, or nearly flat marginal terraces near the top (Lonsdale, et al., 1972), and the steep side slopes of the guyot which plunge to abyssal depths. Of all the features of a guyot, the main 


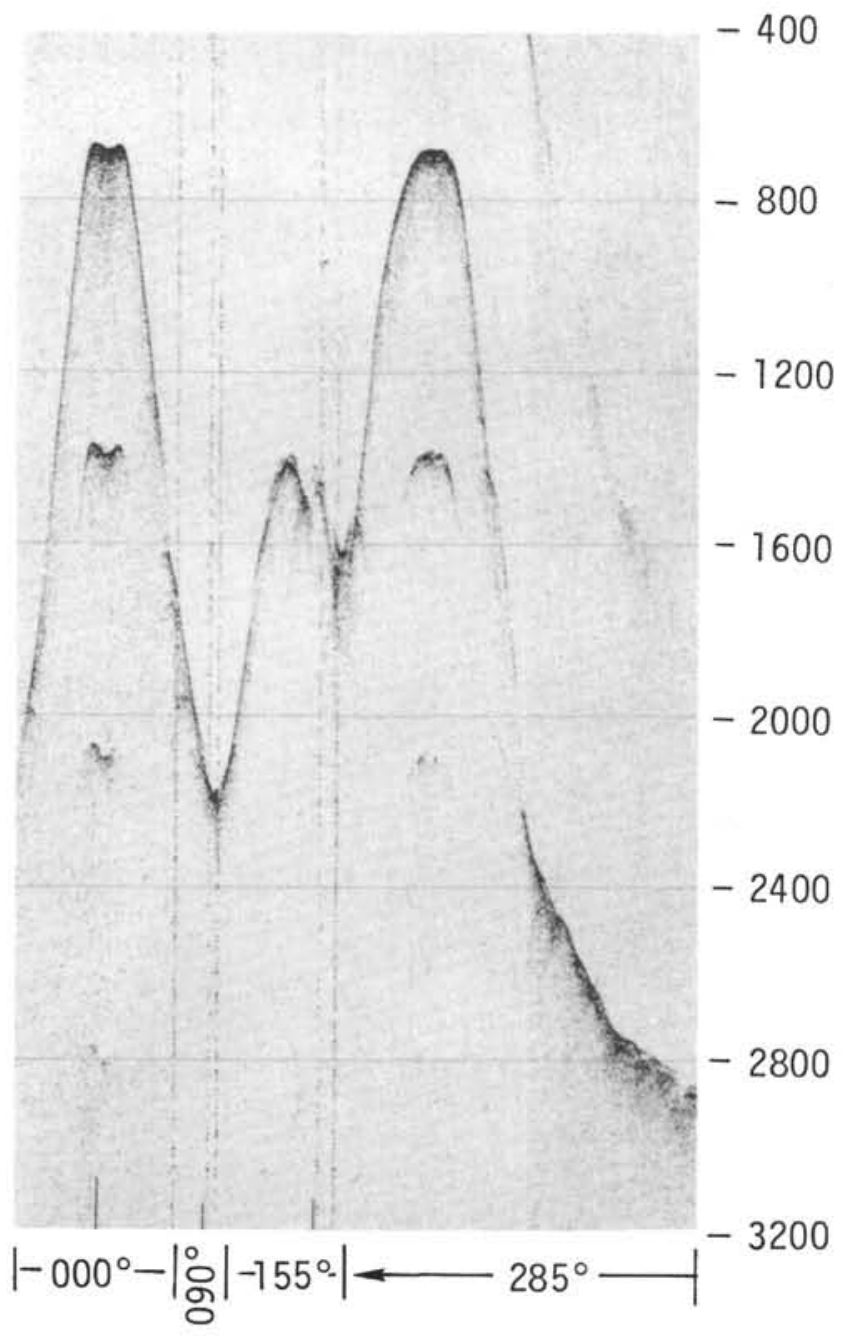

Figure 17. Two seismic reflection profiles of Darwin Guyot. Note the absence of a transparent layer from the small summit. There is some suggestion of deeper layers.

break in slope is the most likely place to dredge in situ or sedimentary fragments of fossil reefs. DSDP Site 171 is located in a saddle between the two guyot platforms of Horizon Guyot (Winterer, et al., 1973).

Two dredge hauls (MP-25-1F and MP-25-2F, Table 2) from the western platform recovered manganese-oxidecrusted hyaloclastites and volcanic pebbles described as olivine basalt by Hamilton (1956, p. 9). The baslat pebbles are angular or subrounded. Some are crusted with hyaloclastite material, indicating extrusion under water. The basalt has about 10 percent microphenocrysts of olivine altered completely to talc and iron oxides and is dominated by flow-oriented elongate laths and acicular needles of labradorite $\left(\mathrm{An}_{69-65}\right)$. Glass is abundant although altered to clays or stained with red iron oxides. Small clear crystallites of pigeonite can be identified in the unaltered glass.

The larger eastern platform was dredged twice within the area of a near-bottom survey undertaken using Scripps
Institution of Oceanography's Deep Towed Instrument Package (Lonsdale et al., 1972). Both dredge hauls were across scarps, one at the outer edge (the main break in slope) and the other, of less than 100 meters relief, on the main guyot platform. The outer edge dredge (STYX 2) recovered a small amount of manganese-oxide-crusted hyaloclastite and a few basalt pebbles. The hyaloclastite consists of orange palagonitized vitrophyre fragments embedded in a matrix of even more altered crushed glass derived from the edges of the large glass fragments. It includes one fragment with a fresh, brown sideromelane core carrying a few percent fresh quench olivine and bytownite $(A n 79)$ laths. A few tiny specks of clinopyroxene, too small for precise optical determinations, dot the brown glass.

The dredge haul from the short terrace scarp on the main platform (7TowVI-143-D) recovered large amounts of angular to rounded fragmental basaltic material. These occur either as manganese- and phosphorite-cemented conglomeratic boulders or as isolated manganese-crusted cobbles. Forth-one thin sections reveal only minor variation. All rocks are basalts with between 10 and 25 percent altered olivine phenocrysts and 5 to 30 percent plagioclase phenocrysts. Feldspar compositions range from $\mathrm{An}_{71}$ to An65 for phenocrysts and $\mathrm{An}_{65}$ to $\mathrm{An}_{57}$ for groundmass laths. Where the rocks are sufficiently fresh, tiny elongate needles or equant prisms of clear pigeonite can be seen. Pyroxene phenocrysts were not found.

Rocks cored at DSDP Site 171 (Bass et al., 1973) are low potash tholeiitic basalts with phenocrysts of olivine and plagioclase. Two of the analyzed rocks have 0.20 percent $\mathrm{K}_{2} \mathrm{O}$ and 0.34 percent $\mathrm{K}_{2} \mathrm{O}$; a third has 1.07 percent $\mathrm{K}_{2} \mathrm{O}$. According to Bass and coworkers, the first two have $\mathrm{K}_{2} \mathrm{O}$ levels similar to oceanic tholeiites, while the third resembles Hawaiian tholeiites. Secondary enrichment of potash during weathering was inferred to be insignificant by those authors.

The rocks dredged and cored from Horizon Guyot are all similar in having olivine and plagioclase phenocrysts. Rocks from two of the dredge hausl also have pigeonite, thereby suggesting tholeiitic compositions. The pyroxenes from the cored basalts (Leg 17 DSDP) are only described as clinopyroxenes, but the chemistry of the rocks indicates they are tholeiitic as well. Rocks dredged from Horizon Guyot are thus olivine-plagioclase basalts with chemistry or mineralogy indicating tholeiitic compositions.

Horizon Guyot is at least as old as Albian; fossils of that age were recovered in dredge 7Tow VI-143-D (Lonsdale et al., 1972). Shallow-water megafossils and plant remains were cored at DSDP Site 171, the first evidence that any part of the guyot had ever been at sea level (Winterer et al., 1973). The oldest fossils identified at this site, Cenomanian in age, were drilled about 125 meters above basement at this site and near a flow interlayered with marine sediments which is therefore dated as mid-Cretaceous. Recovery was poor in the last 130 meters and fossils lacking. The final core recovered volcanic rocks possibly as old as 120 million years if sedimentation rates up to the Cenomanian are extrapolated to the basement depth. 


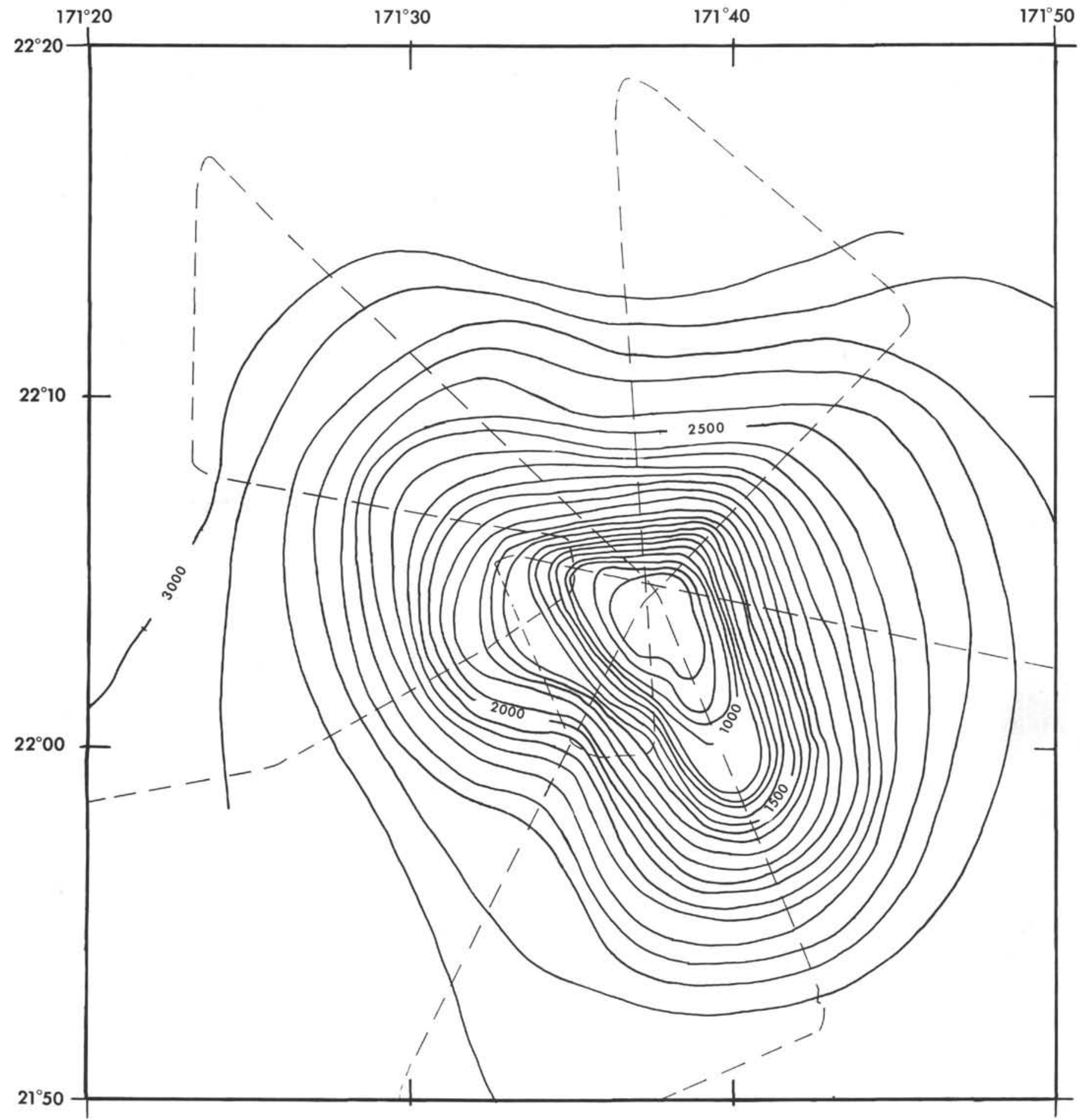

Figure 18. Bathymetric sketch of Darwin Guyot based on the ARIES V survey.

Rocks Dredged by ARIES $V$ from the Mid-Pacific Mountains

Rocks petrographically similar to those from Horizon Guyot were dredged on ARIES V elsewhere in the Mid-Pacific Mountains.

A dredge haul from Shepard Guyot includes reef limestone, badly altered volcanic fragments of hyaloclastite, and a few angular pieces of altered basalt. Altered olivine microphenocrysts and laths of calcic andesine characterize the rocks. No pyroxene is fresh enough to identify. Groundmass olivine is absent. The intermediate feldspar composition suggests a fractionated rock composition, possibly a ferrobasalt, the usual intermediate rock type of tholeiitic differentiation series.

Rocks dredged from a deep escarpment at the western margin of the Mid-Pacific Mountains contain minor olivine microphenocrysts, now altered to talc and iron oxides, more abundant clear augite phenocrysts, and common laths 

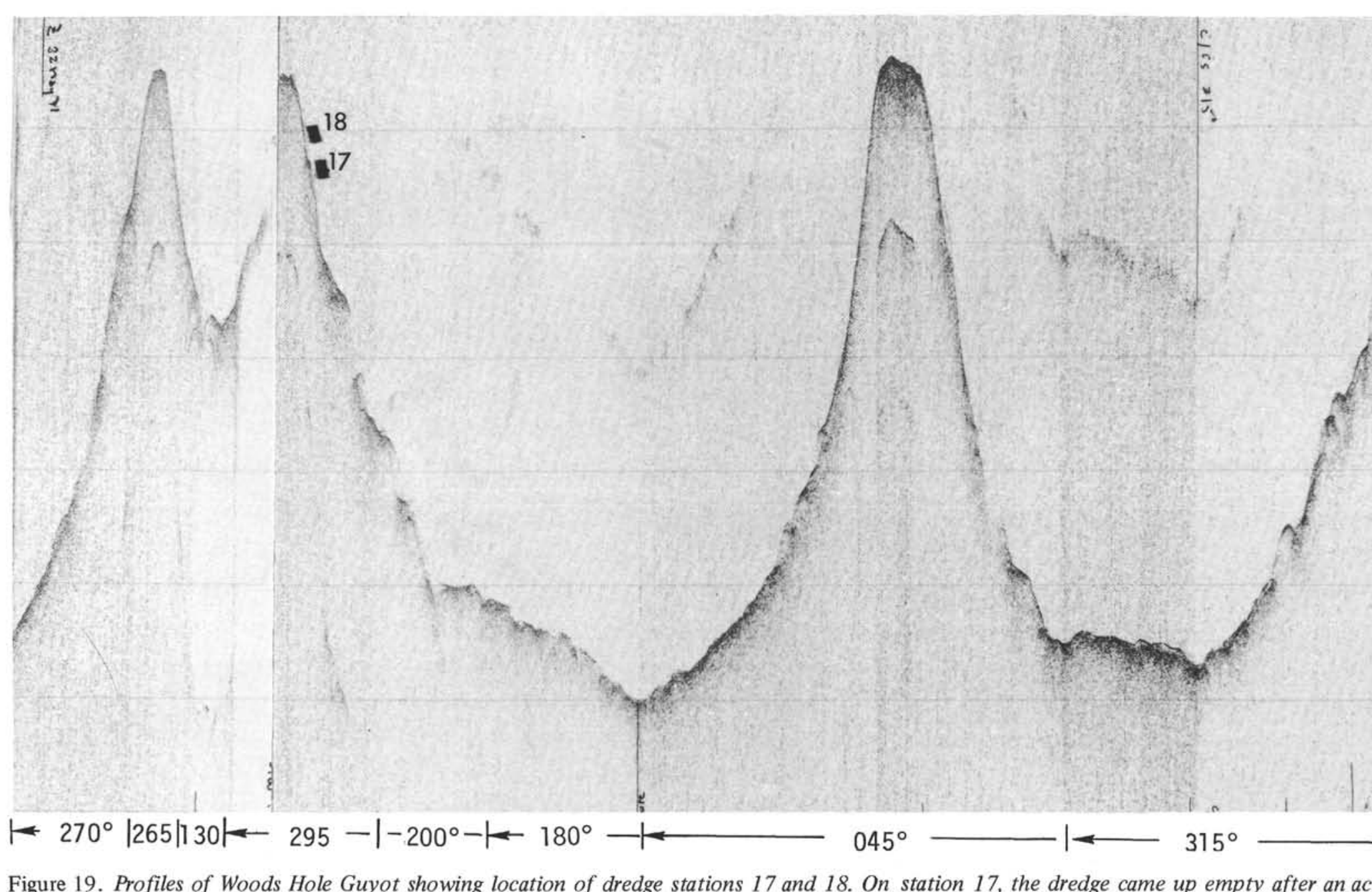

$-800$

$-1200$

$-1600$

$-2000$

$-2400$

$-2800$

Figure 19. Profiles of Woods Hole Guyot showing location of dredge stations 17 and 18. On station 17, the dredge came up empty after an active battle with a rough bottom. On station 18 the dredge became entangled with the bottom and was lost. 


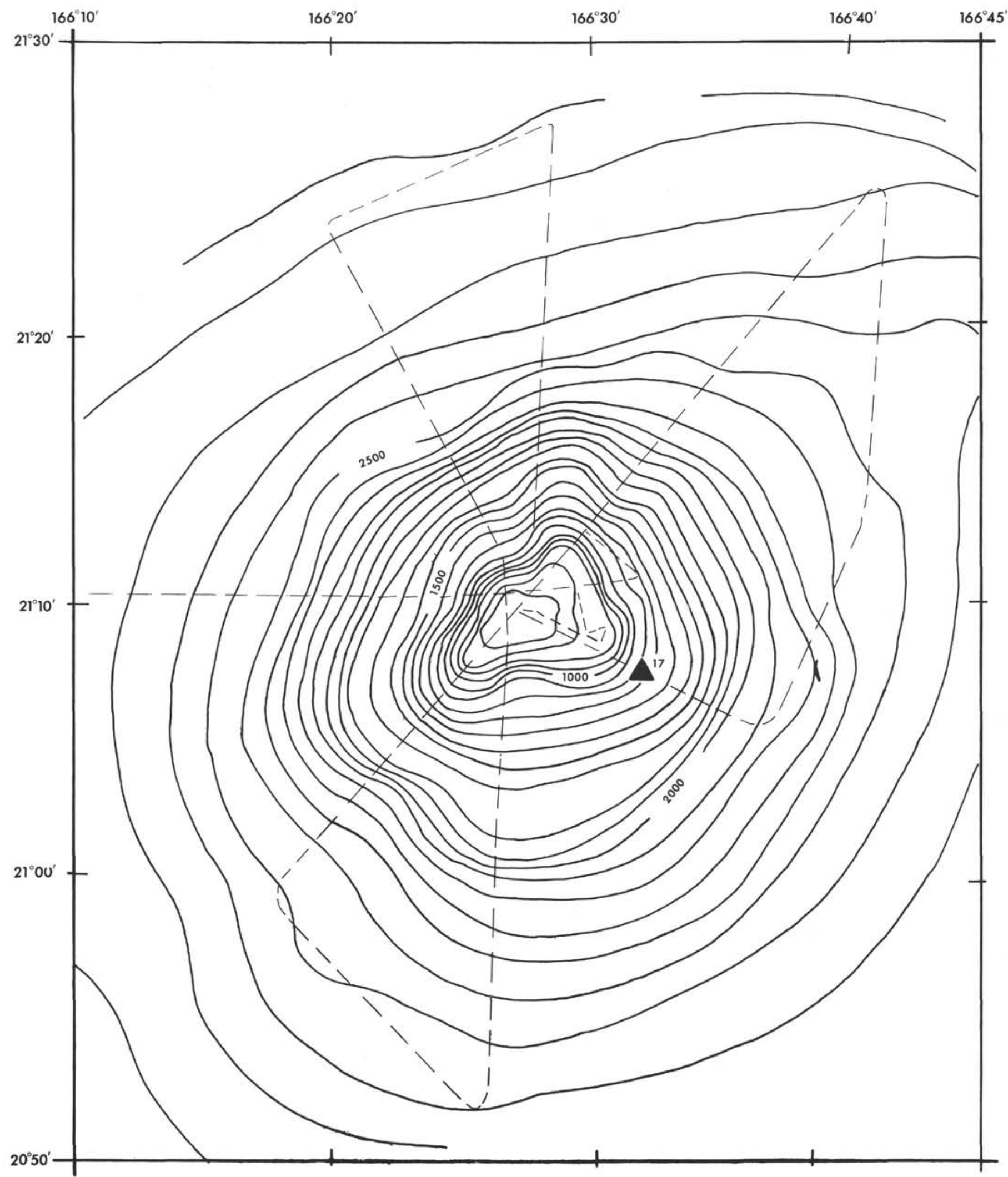

Figure 20a. Bathymetric sketch of Woods Hole Guyot.

or clumps of labradorite $\left(\mathrm{An}_{55}\right)$ phenocrysts. Groundmass plagioclase needles are calcic andesine. Criss-crossed chains of opaques and small grains of pigeonite are arranged intersertally with the feldspars. Alteration is intense. Cores in zoned plagioclase phenocrysts are replaced with sanidine; clays after glass are abundant. The somewhat sodic 


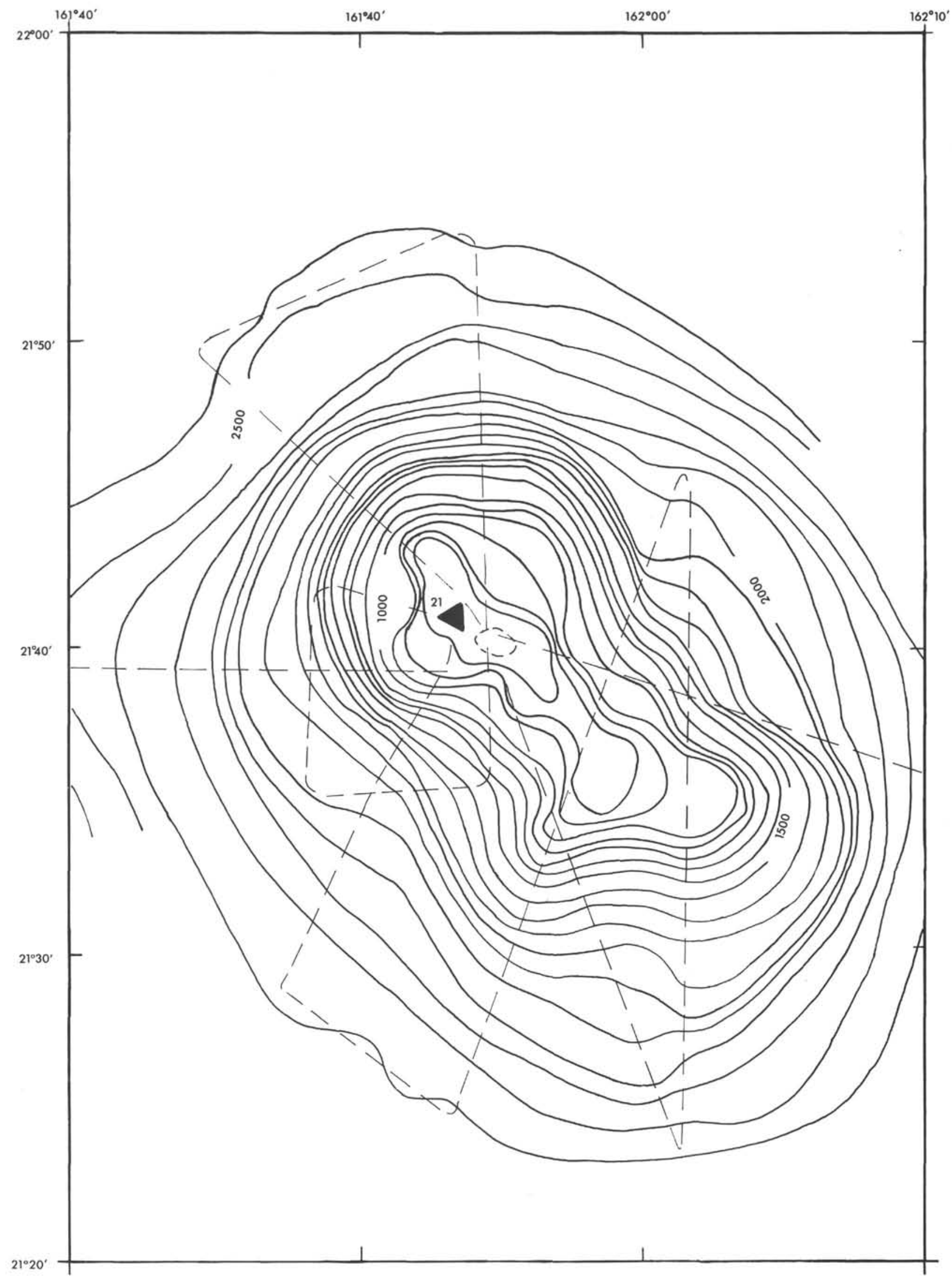

Figure 20b. Bathymetric sketch of Miami Guyot. 


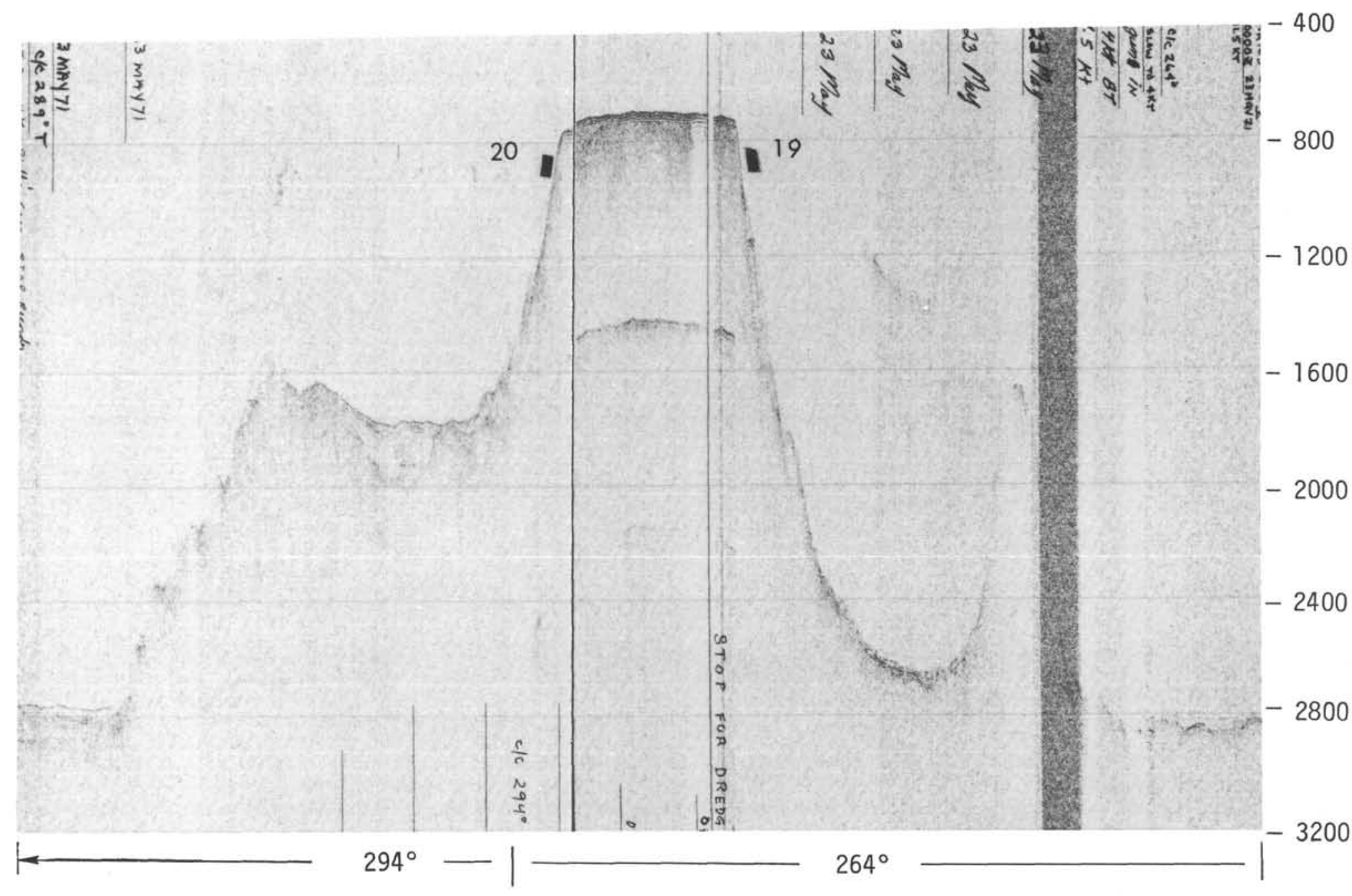

Figure 21. Seismic reflection profile of Wilde Guyot showing location of dredge hauls. Phosphatized manganese coated chalks obtained in both hauls (19 and 20) contained volcanic fragments and mid-Eocene foraminifera. The upper transparent layer is totally absent and the profile denies the possibility of a thick sequence of opaque sediment. 


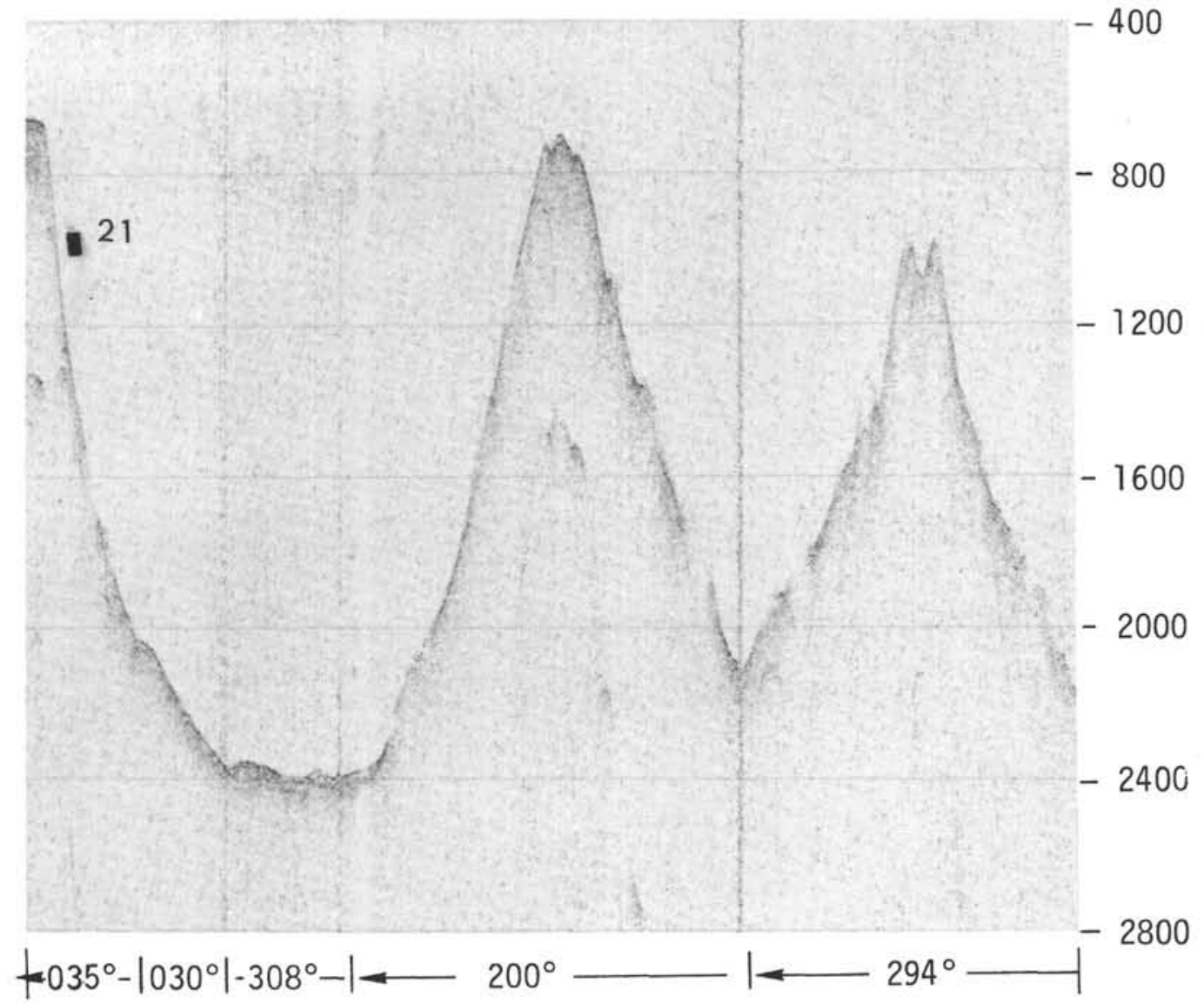

Figure 22. Dredge haul 21 located on Miami Guyot obtained volcanic breccia and phosphatized middle Eocene pelagic limestone.

groundmass feldspars and presence of two pyroxenes suggest that these rocks are differentiates of tholeiitic basalts, perhaps ferrobasalts in composition.

A rock dredged from Menard Guyot along with reef limestone is about 60 percent slender laths of andesine $\left(\mathrm{An}_{37}\right)$ in a trachytic groundmass which contains abundant opaques and altered needles of iddingsite after olivine. Potash oligoclase, a feldspar with a low positive optic angle (Macdonald, 1942), is abundant as low-relief patches between andesine needles. Macdonald and Katsure (1964) consider this mineral to be typical of alkali basalts and subsequent differentiates. It is commonly found in mugearites (also called oligoclase andesites) of alkalic series of Hawaii and Scotland (Muir and Tilley, 1961). Its presence in this dredged rock along with andesine suggests that the rock should be given the alkalic series name of hawaiite (andesine andesite). If this is correct, it contrasts with tholeiitic series rocks (inferred from petrographic or chemical data) from elsewhere in the Mid-Pacific Mountains.

\section{Necker Ridge}

The summit of Necker Ridge was dredged at $21^{\circ} 32^{\prime} \mathrm{N}$, $167^{\circ} 56^{\prime} \mathrm{W}$. Slabs and cobbles of volcanic rock, thickly crusted with manganese oxides, plus manganese-crusted burrowed muds rich in barite were the major materials recovered. Globigerina ooze in manganese crusted slabs included forms comparable to Praeglobotruncana (?) or Truncorotaloides, age Cretaceous of Paleogene, as determined by the late E. C. Allison. Other early middle Eocene and Miocene or later fossils were also identified. The igneous rocks included a large rounded boulder of theralite, an alkali gabbro. An experimental K-Ar age of 61.3 m.y. was obtained on this rock (Ozima and others, in preparation). There is thus reasonable correlation between radiometric and fossil ages for materials from this dredge haul. Both ages, though, are probably minimum ages; the gabbro is somewhat altered. But neither is close to the Albian fossil age of nearby Horizon Guyot. These two nearly parallel ridges may differ in age by thirty million years or more. Necker Ridge is structurally contiguous with Necker Island, part of the Hawaiian chain. K-Ar experimental ages from Necker Island, however, are much younger than the 61.3 m.y. radiometric age reported here for Necker Ridge (11.3 \pm 1.2 m.y., McDougall, 1964; $9.5 \pm 0.5$ m.y., Jackson and others, 1972). Necker Ridge is thus older than adjacent portions of the Hawaiian chain of volcanoes.

Rocks dredged from Necker Ridge are characterized by pink titan-augite, groundmass olivine, and potash oligoclase, all typical minerals of mafic alkalic rocks. The gabbro has about 20 percent altered olivine phenocrysts and abundant titanaugite laths interlocked with andesine $\left(\mathrm{An}_{37}\right)$. Potash oligoclase riddled with apatite needles forms patches with 


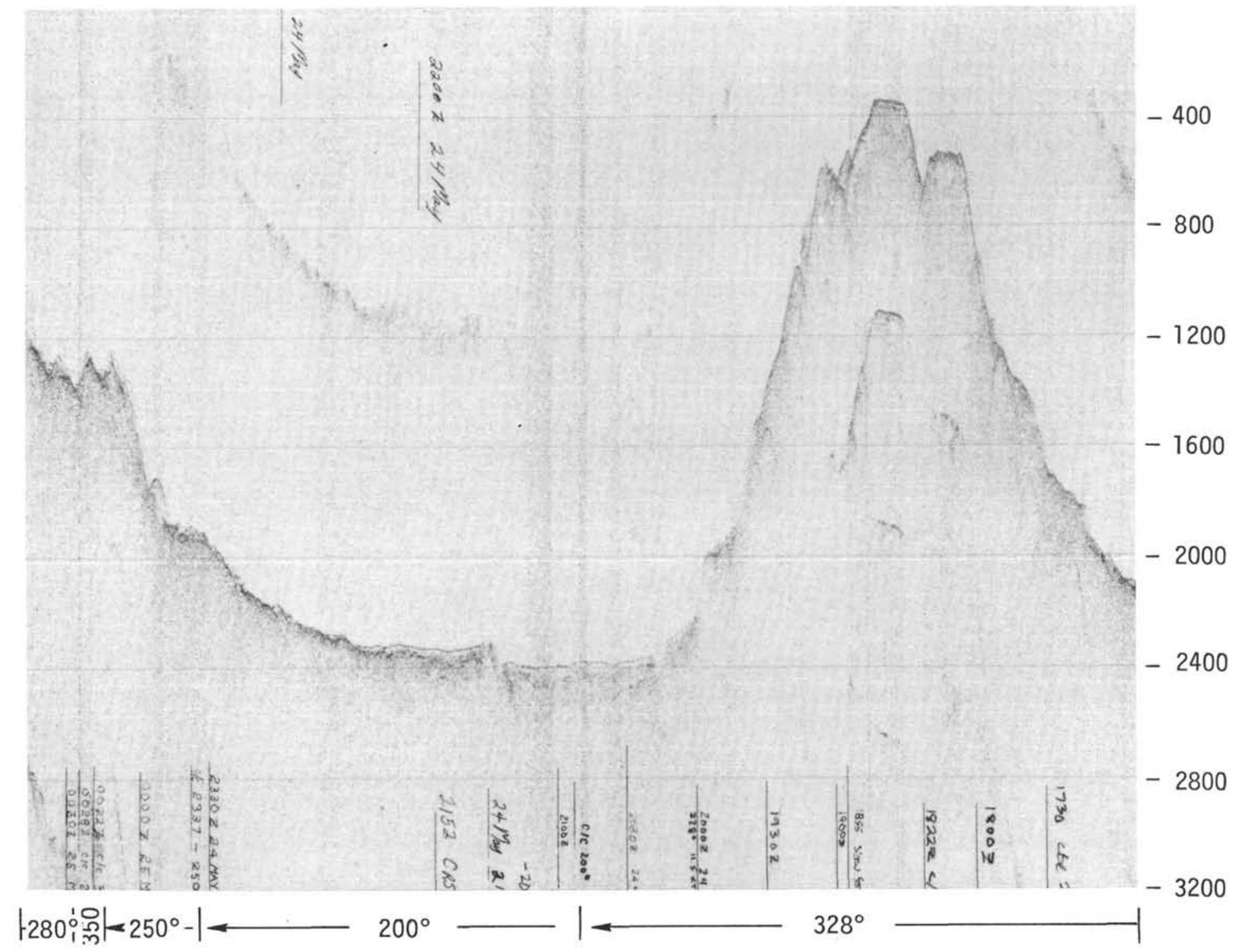

Figure 23. Seismic profile of complex summit of Ladd Guyot. 


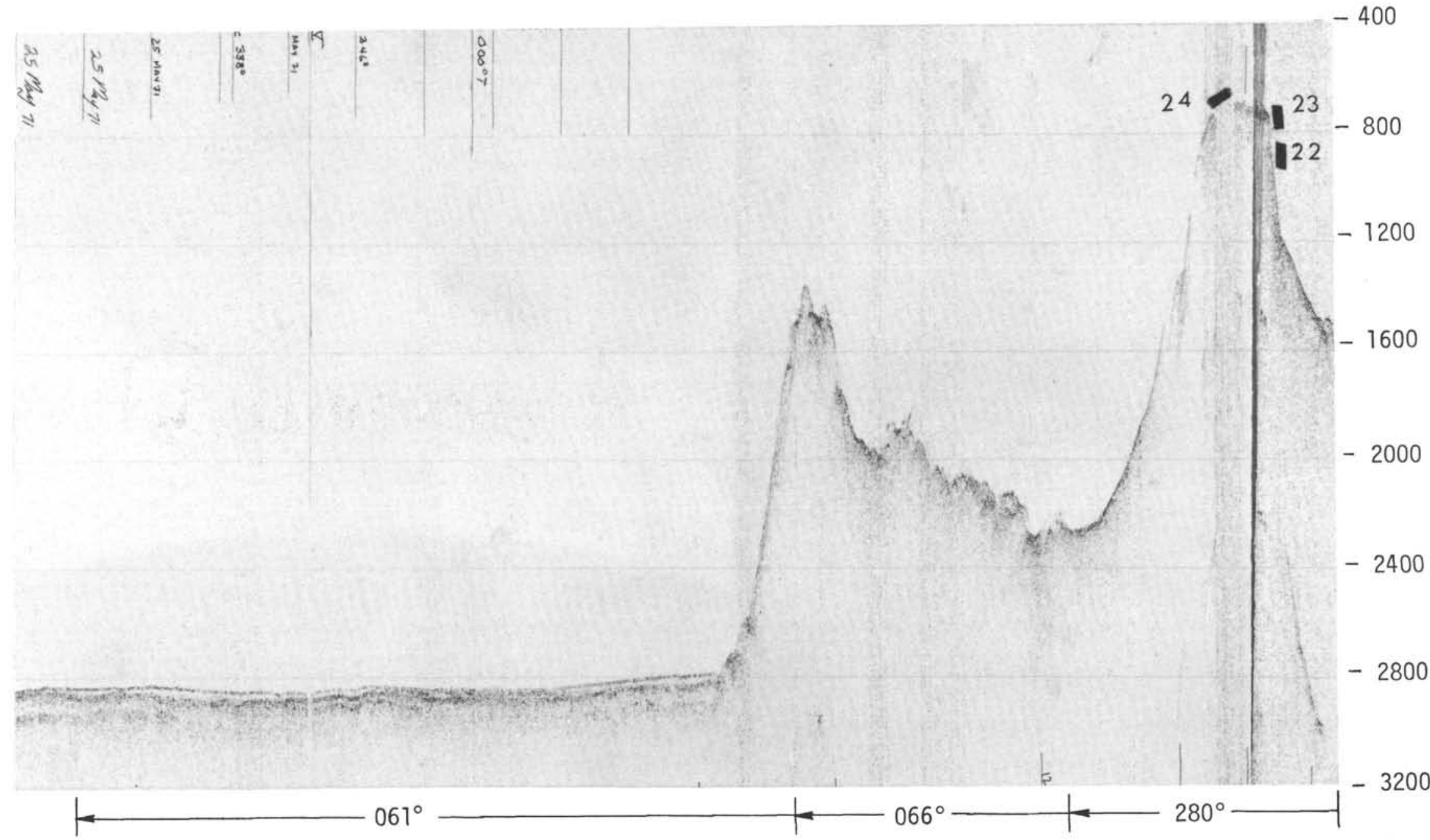

Figure 24. Dredge hauls 22, 23 and 24 from Lamont Guyot in the Wake group obtained a mixture of volcanics and phosphatized Eocene pelagic limestone. A transparent cap is not present and there is no suggestion of deeper reflectors. The former volcanic island must have submerged shortly after its birth without the establishment of reefs. 


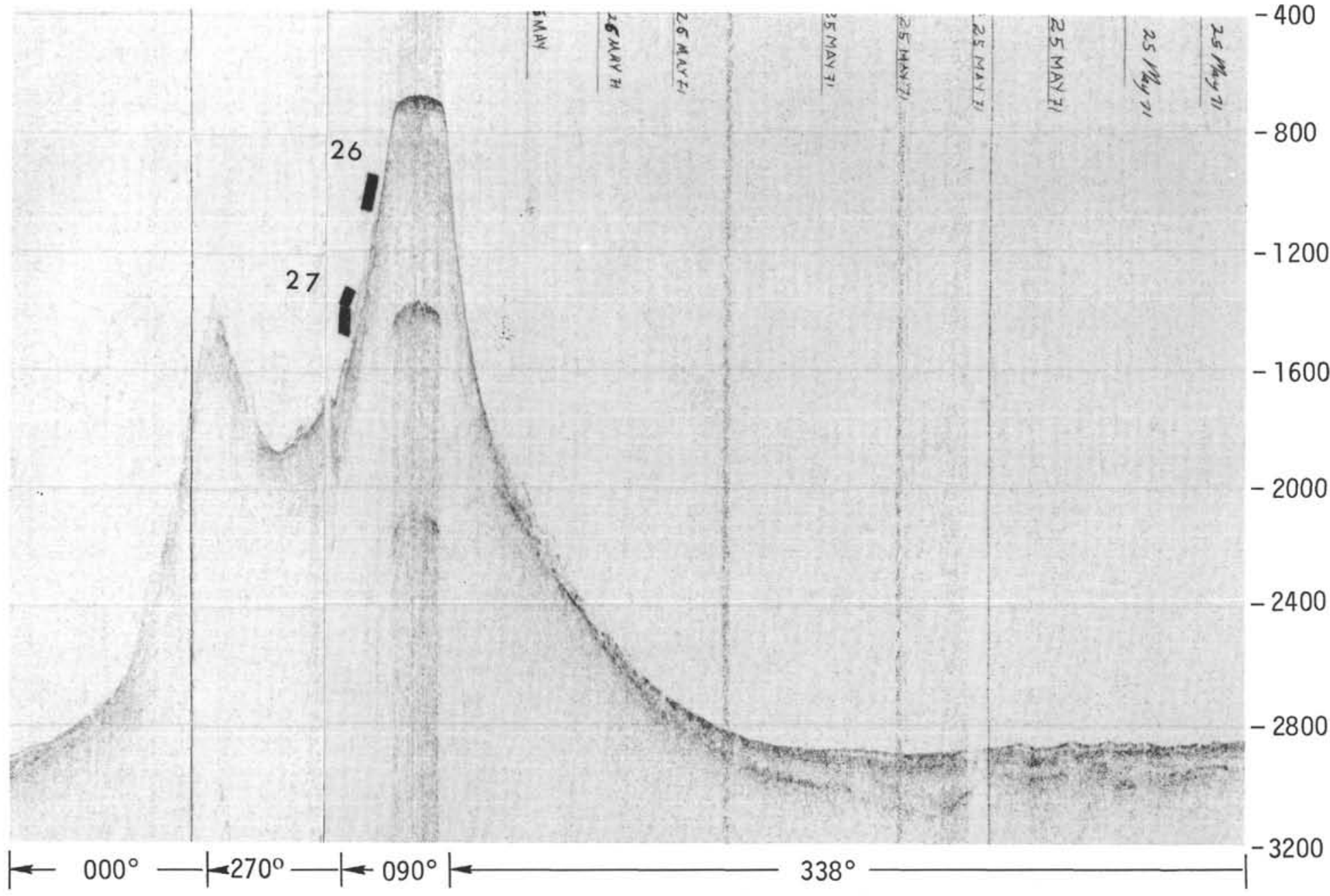

Figure 25. Dredge hauls 25 and 26 from the north flank of Scripps Guyot obtained volcanic fragments and white phosphatized chalk of Eocene age. Dredge 27 deep on the flank obtained a porous manganese coated phosphoritic with ghosts of the Cretaceous species Globotruncana $s p$. This is the oldest fossil obtained in the Wake area guyots and was recovered at this single location. It suggests that Scripps Guyot, at least, is as old as Late Cretaceous. None of the Wake area guyots yielded reef materials. Although the existence of shallow-water conditions may be indicated by the rounded volcanic cobbles this is of uncertain significance. 


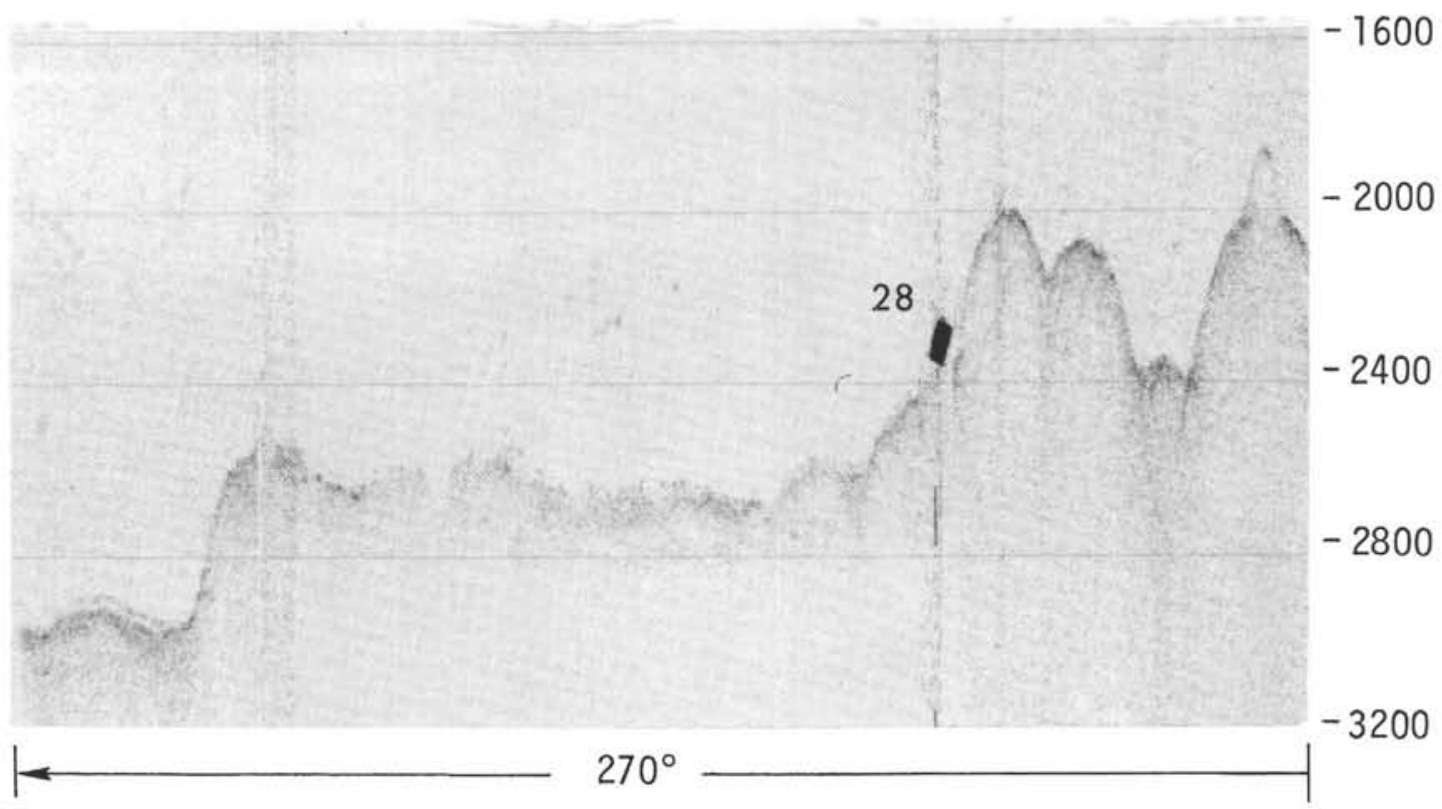

Figure 26. Seismic reflection profiles across topographic irregularities near the southern margin of the Shatsky Plateau. Dredge 28 recovered a small amount of olovine basalt together with radiolarian ooze.

irregular extinction and lower relief between plagioclase and clinopyroxene grains. The pyroxene has a low positive optic angle of $30^{\circ}$ or less, variable with zoning. However, it is not pigeonite or subcalcic augite. Macdonald (1968a) has described calcic clinopyroxenes high in titania with similar optics and coloration from American Samoa. The titanaugites differ from the pigeonites described earlier in being pink rather than clear and in having somewhat higher optic angles $\left(20^{\circ}-30^{\circ}\right.$ rather than $\left.0^{\circ}-10^{\circ}\right)$. Some of the titanaugites in the theralite are rimmed with green aegerine augite, a further indication of alkalic chemistry. A few interstices in the gabbro are filled with variolitic titanaugite-plagioclase basalt, suggesting that the rock was inundated by a later flow that was quickly cooled. The intrusive rock was perhaps exposed by faulting or entrained as a xenolith to allow this sequence. The gabbroic rock dredged is also a manganese-crusted subrounded boulder. There is no nearby wave-cut platform; the boulder's roundness is apparently the result of submarine rather than subaerial or littoral erosion. Exposure of an intrusive mass, inundation by a later volcanic event, re-exposure, detachment from its outcrop, and submarine abrasion of its edges are thus all recorded in a single rock, all testimony to the great instability of steep volcanic slopes during and after submarine volcanism.

Basalts in the dredge haul are almost equigranular labradorite-titanaugite basalts, with sparse altered olivine microphenocrysts. Titanaugite is prevalent, but interstitial feldspars are almost entirely replaced by clear clays. Iddingsite has replaced groundmass olivine. These rocks, too, are crusted thickly with manganese oxides. Unlike the gabbro, they are extremely angular with rough and irregular contacts with the black manganese oxides. No glassy margins, joints or pillow structures are observable. They apparently fractured and slumped away from their original outcrops and are now completely encased in manganese, typically thicker on the side exposed to seawater.
In summary, rocks older than the Hawaiian chain and younger than guyots in the Mid-Pacific Mountains have been dredged from the top of Necker Ridge. They are certainly part of an alkalic rock suite, in contrast with the vast bulk of tholeiitic basalts from the Hawaiian chain and the tholeiitic rocks dredged and cored from Horizon Guyot.

\section{Petrography of Rocks Dredged from the Wake Guyot Group}

Rocks dredged from guyots in the Wake group contrast strongly with the predominantly tholeiitic rocks of similar age in the Mid-Pacific Mountains. Instead of olivine and plagioclase, titanaugite is the predominant phenocryst and groundmass mineral of basic rocks in the Wake dredge hausl. Plagioclase is notably subordinate. Nepheline and titaniferous amphibole in some of the rocks are further indications of alkali- and titanium-rich silica-undersaturated chemistries.

The most ubiquitous rock among the Wake dredge hauls is limburgite, a mafic volcanic rock dominated by clinopyroxene. It was recovered in four dredge hauls from three guyots. Additionally, an analcime-bearing alkali gabbro and a nepheline-bearing mugearite were retrieved in other dredge hauls.

Limburgites recovered in two dredge hauls from Scripps Guyot are virtually identical. Minor altered olivine phenocrysts and about 5 percent pink titanaugite phenocrysts, some of them with pale green diopsidic cores are up to $0.5 \mathrm{~cm}$ in diameter. Smaller brown pleochroic amphibole phenocrysts are more common, though volumetrically they constitute only a few percent of the rocks. Occasional amphibole megacrysts (up to $3 \mathrm{~cm}$ ) can be seen in the hand speciemsn. The hyalopilitic groundmasses of the rocks have variable amounts of glass, all with abundant titanaugite and much subordinant sodic plagioclase. Both oligoclase and potash oligoclase are present. Two types of iron oxides are abundant-opaque cubic varieties and 


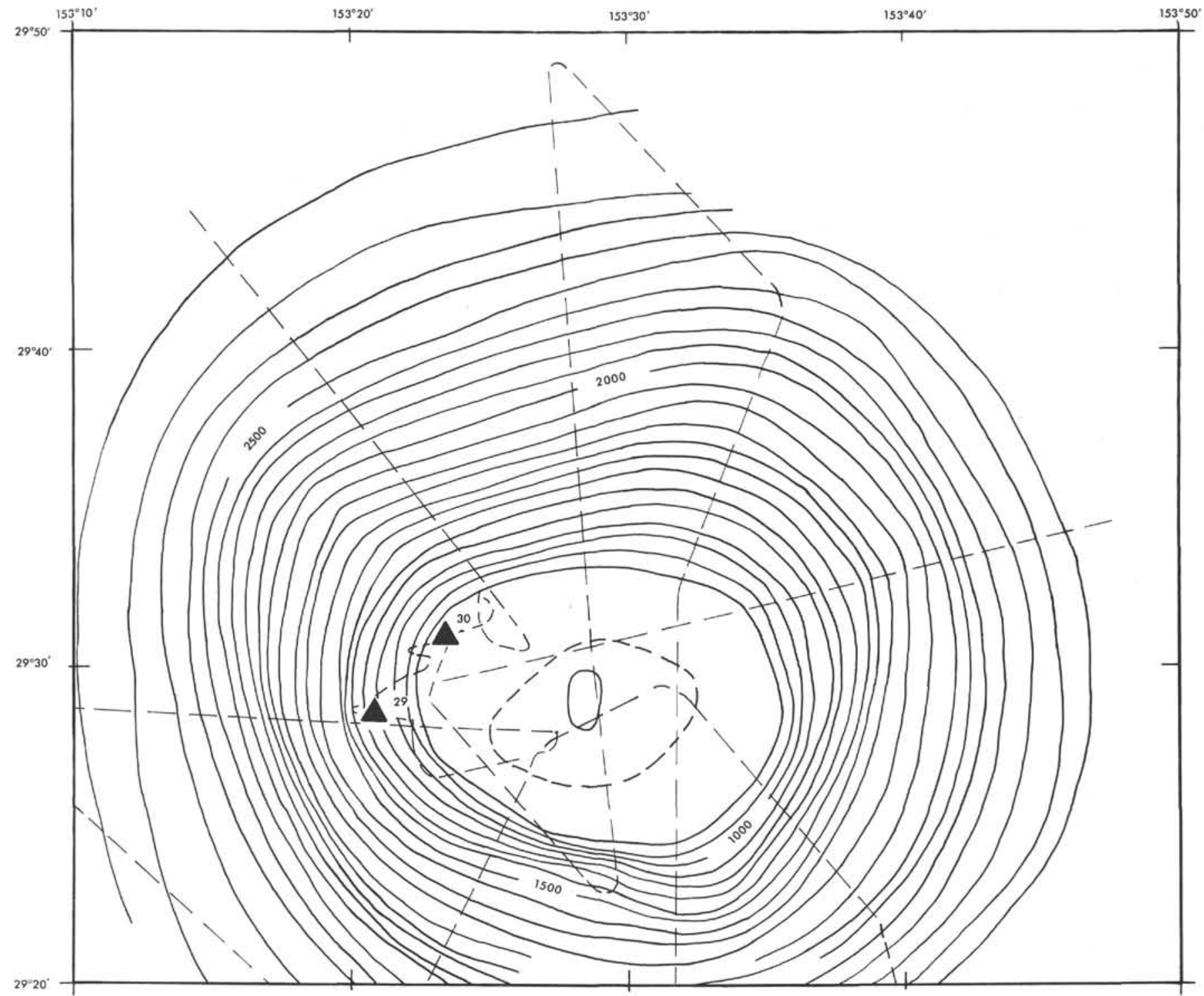

Figure 27. Sketch map of Makarov Guyot showing location of dredge hauls 29 and 30.

octahedral or elongate grains of probably hematite; the latter is absent in areas where glass is still relatively fresh. Nepheline can rarely be observed in the groundmass, and the clinopyroxene and amphibole phenocrysts sometimes enclose euhedral or cigar-shaped grains of apatite.

Limburgite dredged from Miami Guyot is more altered than those from Scripps Guyot and lacks amphibole. Titanaugite is again the major phenocrystal and groundmass mineral. Altered olivine phenocrysts are also present. Andesine and potash oligoclase are subordinant in the groundmass.

Rocks dredged from Wilde Guyot include porphyritic picritic limburgite and mugearite. Highly altered olivine phenocrysts up to $0.5 \mathrm{~cm}$ are almost entirely replaced by clays but still preserve iddingsite rims and form about 40 percent of the porphyritic rock. Clinopyroxene pseudomorphs, replaced by clays, can be distinguished from the altered olivines by lack of iddingsite rims. They are abundant, but not as prevalent as the olivine. The groundmass is relatively fresh and also is dominated by titanaugite with lesser labradorite and potash oligoclase. Some groundmass iddingsite is also present.

The mugearite is a dark gray, fresh, trachytic-textured rock with slender needles of oligoclase $\left(\mathrm{An}_{21}\right)$. Minor clear clinopyroxene and andesine phenocrysts are present; interstitial potash oligoclase is abundant. Occasional nepheline grains can be found, but no olivine.

Olivine theralite dredged from Lamont Guyot is a rounded cobble probably eroded from an intrusive mass by the same processes that leveled the former island to a guyot. Olivine altered to iddingsite constitutes about 30 percent of the rock. Lesser titanaugite, abundant opaques, and minor biotite complete the inventory of ferromagnesian minerals. Labradorite and potash oligoclase, the latter laced with apatite needles, are the feldspars, about 40 percent of the rock. A spherical cavity can be seen in one thin section filled with a low birefringent mineral with low negative optic angle. These are the optical properties of 


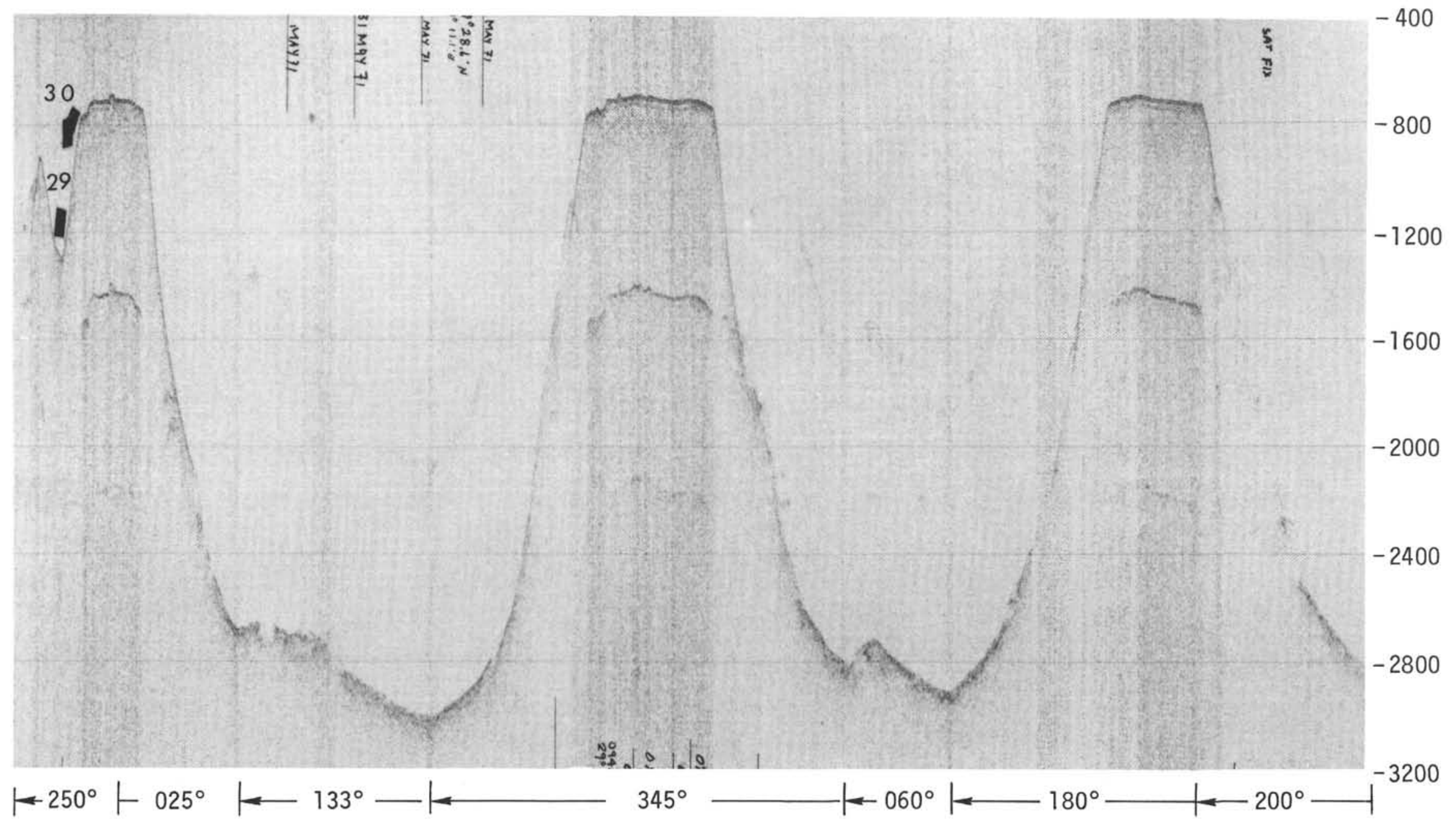

Figure 28. Seismic reflection profiles of Makarov Guyot. Nephelene basalt was dredged at station 29 together with Upper Cretaceous phosphatized bioclastic breccias. Dredge 30 recovered Cenomanian-Senonian phosphatized bioclastic calcarenites containing molluscs. 


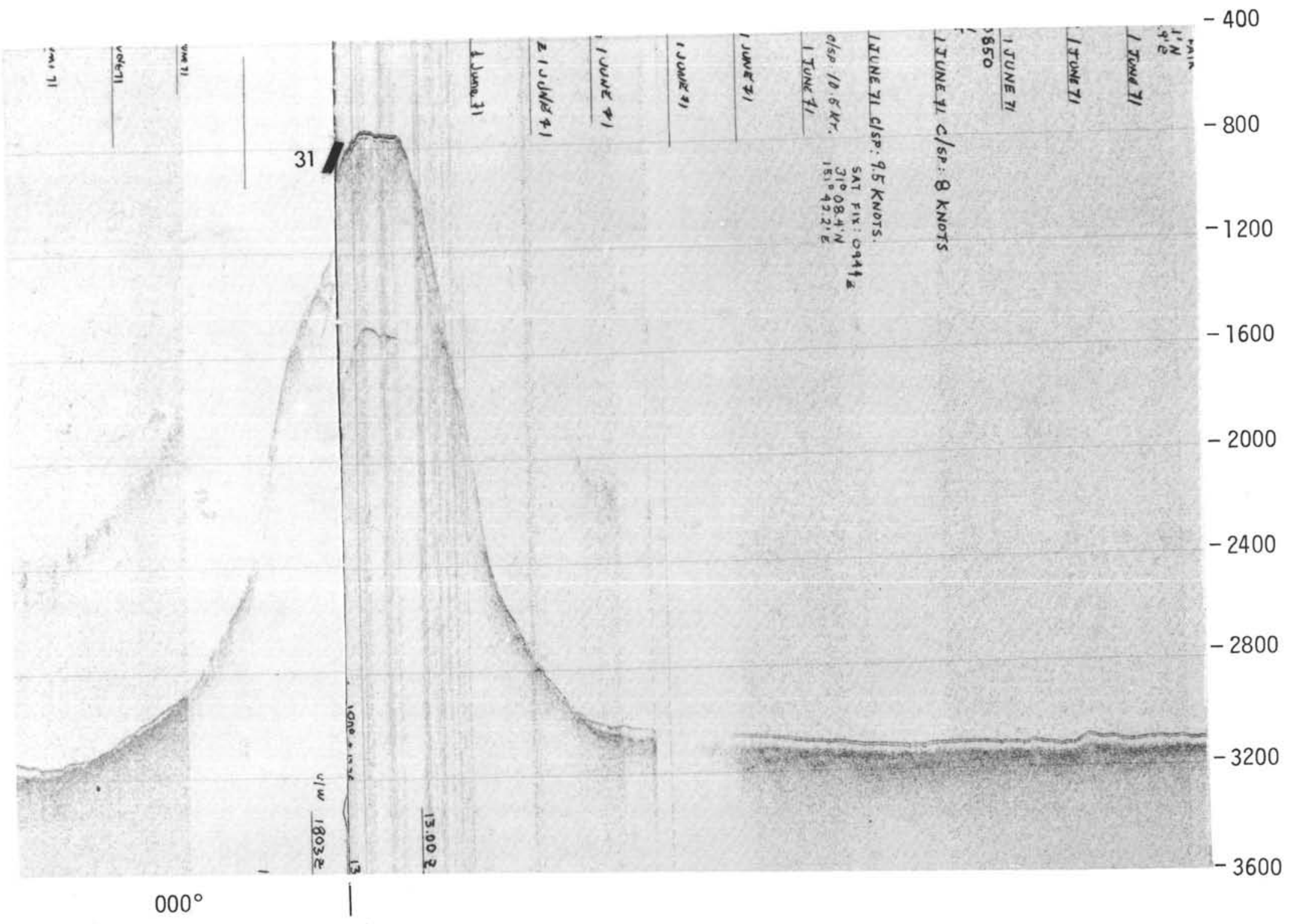

Figure 29. Seismic reflection profiles of Isakov Guyot. The summit survey established that the seamount was a guyot. Dredge 31 recovered Lower Cretaceous rudistid limestones and phosphorites together with Cenomanian-Senonian bioclastic calcarenites. 


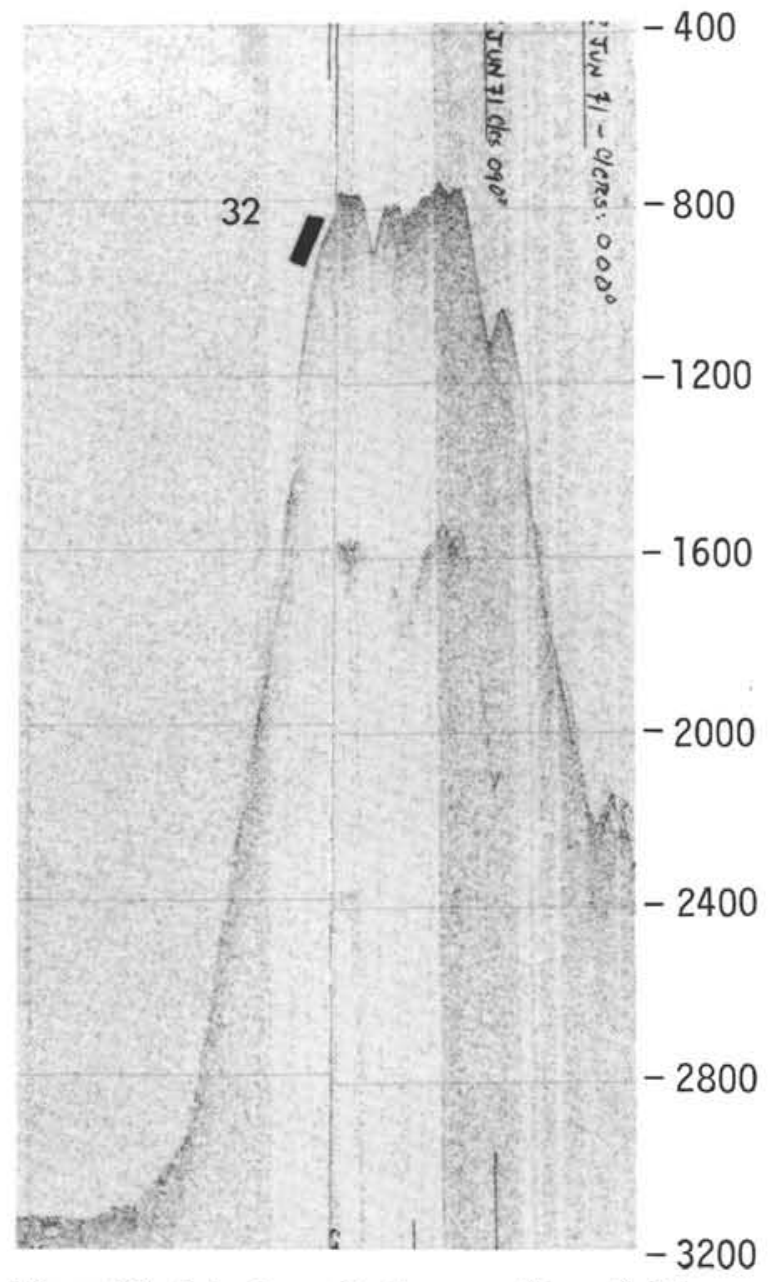

Figure 30. Seismic reflection profile of Thomas Washington Guyot discovered during ARIES $V$. Dredge 32 recovered Cenomanian-Senonian rudist phosphorites and lower-middle Eocene phosphatized chalks.

scolecite, but the mineral is probably analcime which can have similar optics. The cavity is lined with tangential titanaugite, suggesting that the analcime is primary.

The rocks from the Wake group thus all have the mineralogic features of alkalic and strongly alkalic rock suites. Titanaugite, amphibole, and nepheline are the chief diagnostic minerals. Limburgites and related rocks are the most common rock type among the dredged rocks from this group. Petrographic descriptions from the Pacific islands indicate that such rocks are limited to only the most alkalic of island groups, notably Tahiti (Williams, 1933; McBirney and Aoki, 1968), and the Australs (Smith and Chubb, 1927). Their prevalence in the dredge hauls from the Marcus-Wake group implies that these guyots represent a similar strongly alkalic province.

\section{Petrography of Rocks Dredged from the Geisha Guyots}

The Geisha guyots, to the north and west of the groups described above, may represent a petrographic province intermediate to the tholeiitic and alkalic groups so far discussed. Alkali olivine basalt, mugearite, and quartz trachyte dredged from some of these guyots suggest an alkalic province of a mildly undersaturated character, one where early olivine fractionation could ultimately produce free quartz in late differentiates rather than nepheline which is apparent even in the basic rocks of the Wake dredge hauls.

A pillow lava of variolitic texture with abundant, completely latered olivine phenocrysts and doubly-swallowtailed groundmass iddingsite after olivine was dredged from Maiko Seamount. Sheaf-like aggregates of reddish iron oxides after pyroxenes are intermeshed with feldspar needles now completely replaced by clays and alkali feldspars. The variolites, plus chains of trellice-textured opaques and the swallow-tailed olivines suggest rapid quenching, typical of pillow lavas. The groundmass altered olivine suggests the rock was an alkali olivine basalt.

Alkali andesites and trachytes were dredged from two guyots. A gray green rock with minor oligoclase phenocrysts and abundant groundmass potash oligoclase, lesser clinopyroxene, opaques, anorthoclase, and rare nepheline was dredged from Makarov Guyot. Compositionally it is somewhere between a benmoreite and a trachyte. Mugearite, benmoreite, quartz trachyte, and reef limestone were recovered in a single dredge haul from Seiko Guyot. All of the rocks have abundant opaques and are exceptionally fine-grained, holocrystalline, trachytictextured rocks. The mugearite is distinguished by the predominance of oligoclase with lesser potach oligoclase, the benmoreite by the predominance of potash oligoclase, and the trachyte by anorthoclase, sanidine; and lesser potash oligoclase. The quartz in the trachyte occurs rarely in patches and is possibly late stage cavity fillings. Rare clinopyroxene was seen in the mugearite. The abundant opaques give the rocks a dark color so that they are essentially indistinguishable in hand specimen. They are all evidently part of a single differentiation series.

Nepheline-bearing basalt was dredged from Makarov Guyot in addition to the benmoreite just described. The basalt is vesicular, largely glassy, and part of a hyaloclastic pillow breccia. Small titanaugite phenocrysts are present. Groundmass minerals, totalling 30 percent of the rock, are about equally divided between titanaugite and calcic andesine $\left(\mathrm{An}_{49}\right)$. Potash oligoclase and opaques are also present. Small hexagonal nepheline grains can be identified although most of them are now largely replaced by clays.

In summary, rocks dredged from the Geisha guyots, with the exception of the nepheline basalt, are members of the alkali basalt trachyte series. Intermediate and late-stage differentiates were typically dredged. Their analogs on islands might be the alkali olivine basalt-hawaiitemugearite-trachyte or quartz trachyte series of the Hawaiian Islands (Macdonald and Katsura, 1964) or American Samoa (Macdonald, 1968a). They contrast to the clinopyroxene dominated rocks of the Marcus-Wake group in which nepheline is found even in the mafic rocks and which probably preceded phonolitic differentiates, as on Tahiti and the Australs. They also contrast to the typically tholeiitic rocks described from the Mid-Pacific Mountains but not greatly from the two alkalic series rocks described from there. 


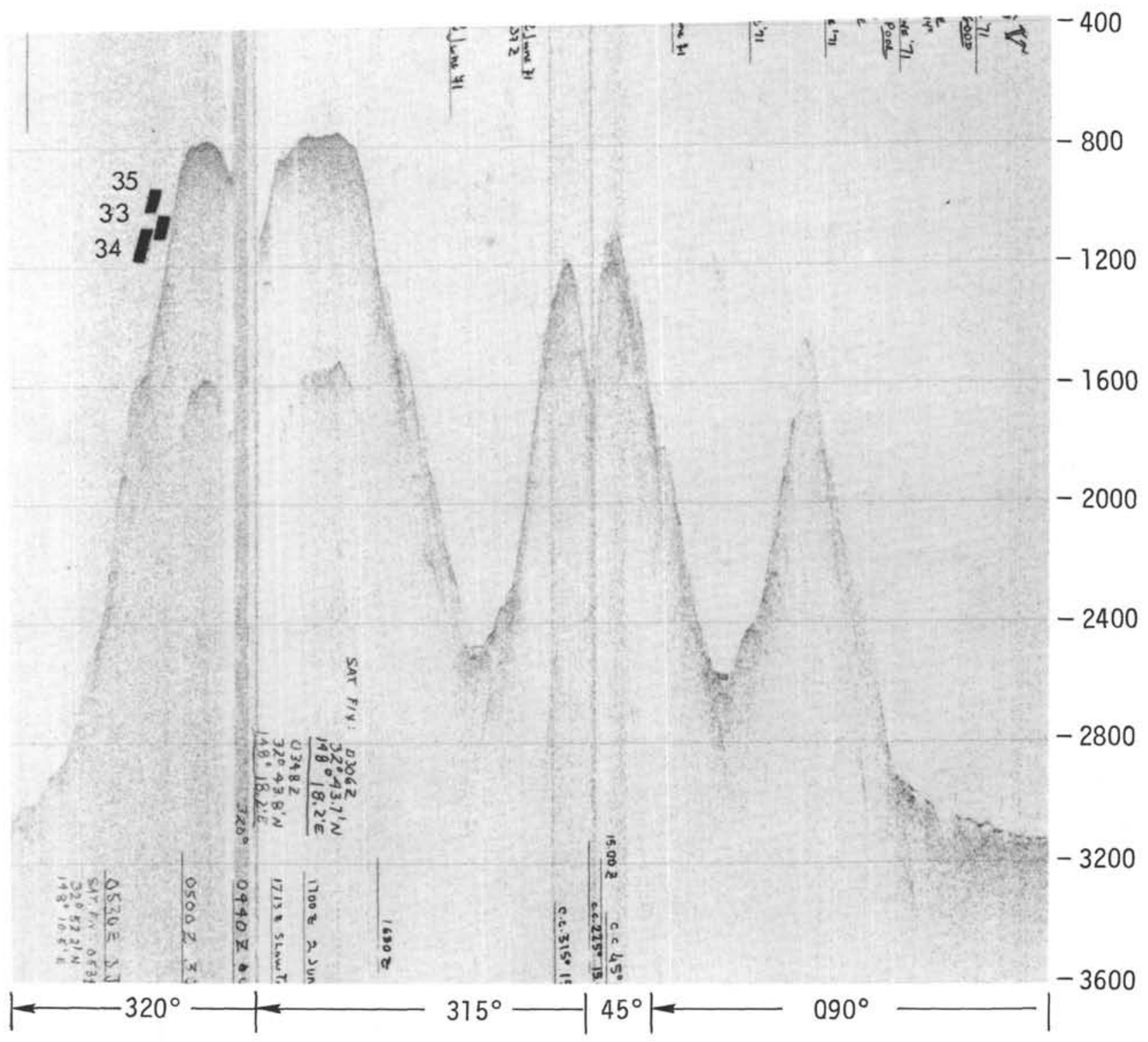

Figure 31. Seismic reflection profile of Winterer Guyot. Dredge haul 33 obtained Cretaceous phosphatized rudistid limestone. Dredge haul 34 offered volcanic ash and Cretaceous bioclastic calcarenites. Dredge 35 obtained only manganese crusts and pumice. Strong current set complicated dredging on Winterer Guyot.

\section{Southern Escarpment of Shatsky Plateau}

Fragments of pillow lavas and radiolarian ooze were dredged from a ridge south of Shatsky Plateau $\left(30^{\circ} 40.0^{\prime} \mathrm{N}\right.$, $\left.158^{\circ} 41.6^{\prime} \mathrm{E}\right)$. The pillow fragments are highly altered and variolitic. Interlocking sheafs of plagioclase and hematite after pyroxene constitute the bulk of the thin section. The sheafs are flecked with abundant secondary opaque iron oxides. A few percent of altered olivine microphenocrysts are replaced by talc and probably goethite. Occasional spoke-like arrays of labradorite zoned to andesine are common. Cores to these crystals are often replaced by sanidine. Though dredged near the Geisha guyots, the basalts have olivine and plagioclase phenocrysts, similar to those of the Mid-Pacific Mountains, and may be altered tholeiitic basalts related to volcanism on the Shatsky Rise.

\section{Hypersthene Andesite from the Geisha Guyots}

A small pebble of hypersthene andesite and a few small pieces of pumice were recovered from Seiko Guyot, the westernmost of the Geisha guyots dredged. The pebble has abundant hypersthene and subcalcic augite phenocrysts but is dominated by plagioclase, up to $0.5 \mathrm{~cm}$ in length. Normal, reverse, and oscillatory zoned feldspars are common. They show pericline, albite, and carlsbad-albite twins and are often joined synneusis clumps. Smaller grains are zoned from about $\mathrm{An}_{59}$ to $\mathrm{An}_{42}$ while the large megacrysts range from $\mathrm{An}_{74}$ to $\mathrm{An}_{24}$. The rock is very fresh. Quartz, albite, and anorthoclase can be identified in the finely crystalline mesostasis. Hypersthene and complexly twinned and zoned feldspars are diagnostic of island arc andesites. The presence of this rock on Seiko Guyot 


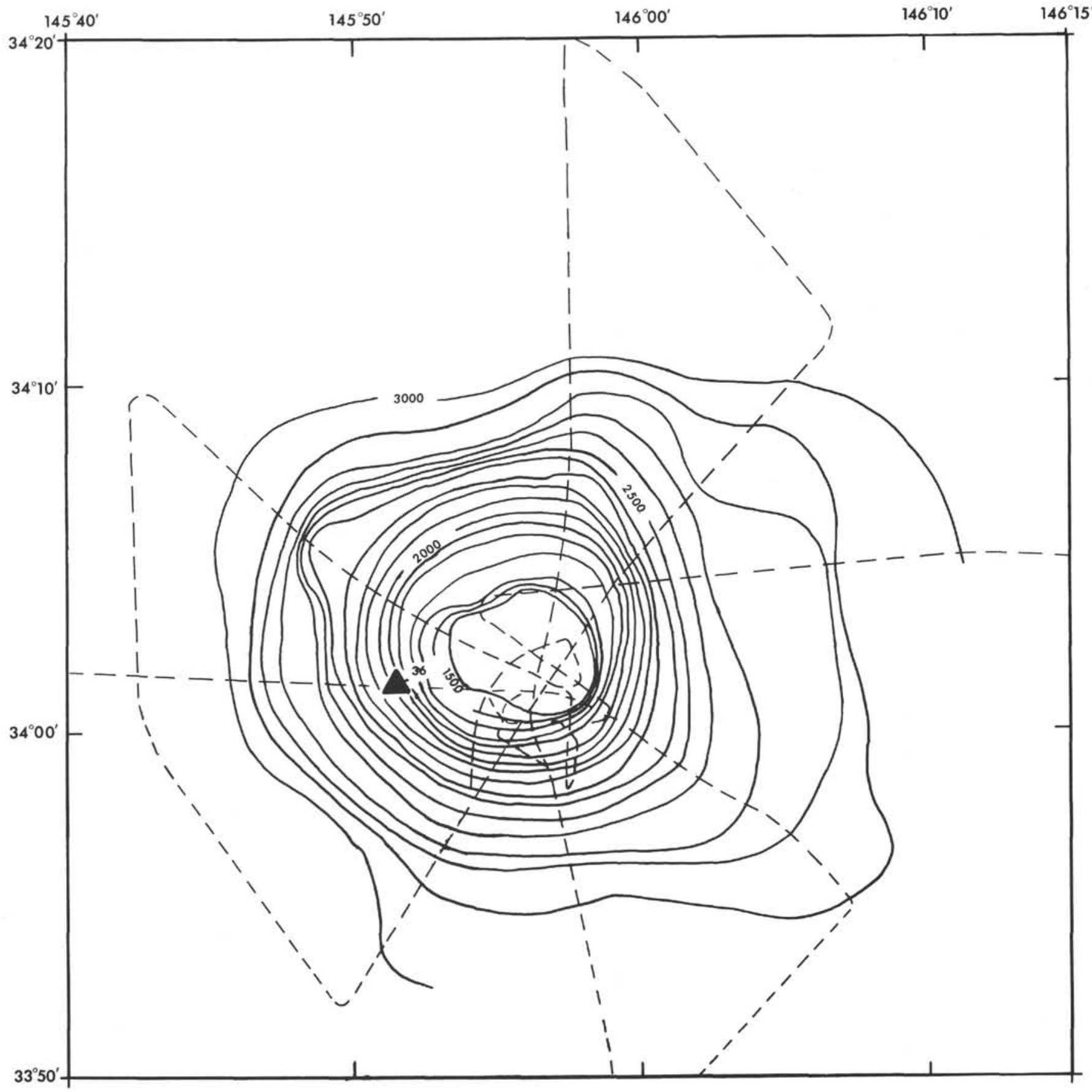

Figure 32. Bathymetric sketch of Maiko Seamount. Dredge haul 36 obtained a large quantity of altered olovine basalt from the flank of this seamount.

contrasts to the alkalic series rocks dredged from nearby guyots and is totally anomalous for ocean basin volcanic series. No rocks of this type have ever been reported from oceanic islands. Therefore, the rock was probably transported from nearby Japan where such rocks are common, presumably by ice-rafting during the Pleistocene. The rock is far too fresh to be as old as the Cretaceous fossils dredged elsewhere on Seiko Guyot. Ice-rafted andesites have been reported from Jimmu Seamount in the Emperor chain (Kuno and others, 1955). Though more northerly in latitude, Jimmu Seamount is much farther from land than Seiko Guyot indicating the effectiveness of ice-rafting of fairly large pebbles far from source island arcs.

\section{DISCUSSION AND CONCLUSIONS}

The meager scrapings of dredge hauls on widely spaced volcanoes leaves much to be desired in terms of statistical significance. The picture is confused by the common occurrence of different rock series side by side or in sequence on well-studied volcanoes. Thus, alkali olivine 


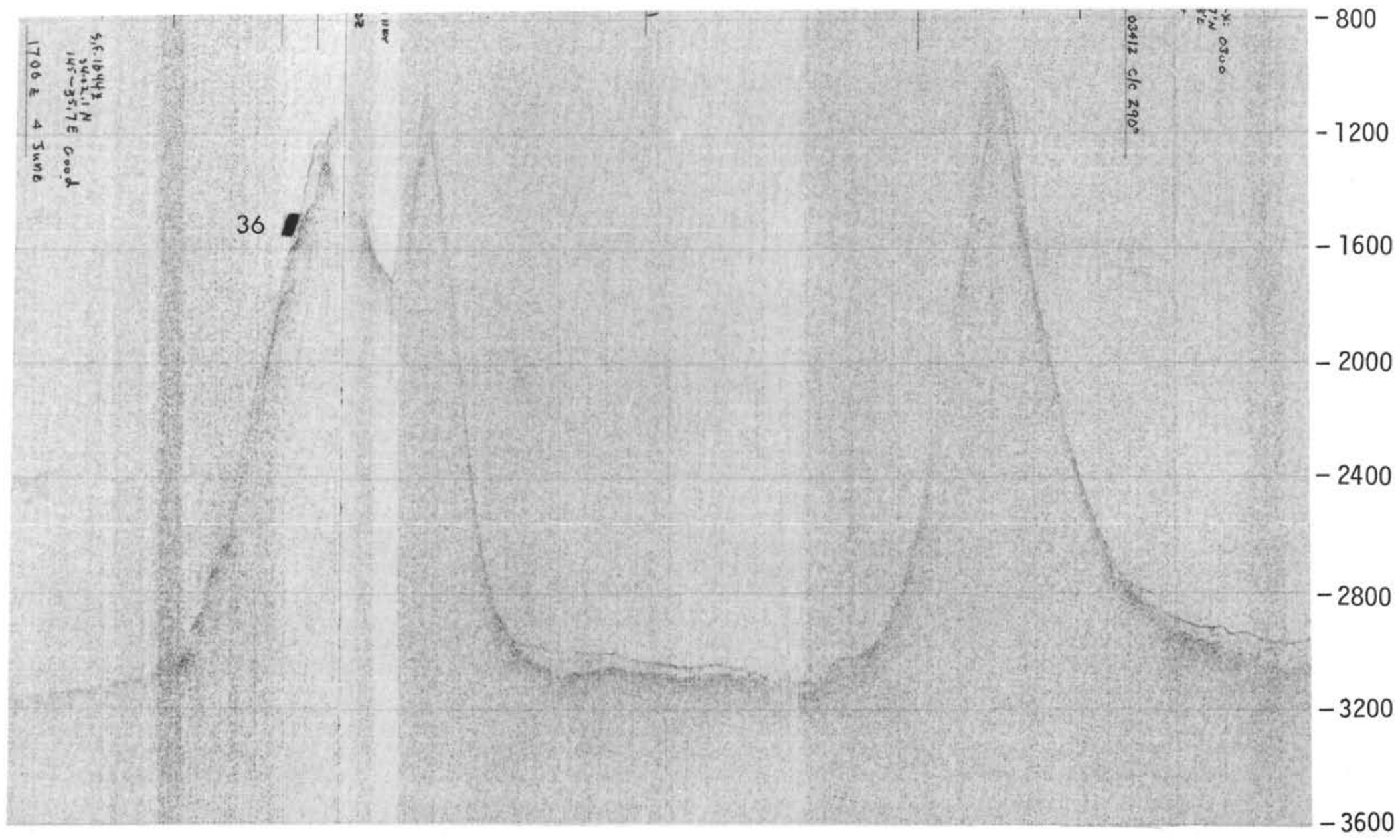

Figure 33. Seismic reflection profile of Maiko Seamount. No sediment is recorded on the top and sides of this seamount. The trainsparent volcaniclastic blanket which spreads out from the Asiatic arcs is present at the base of the current swept mountain. 


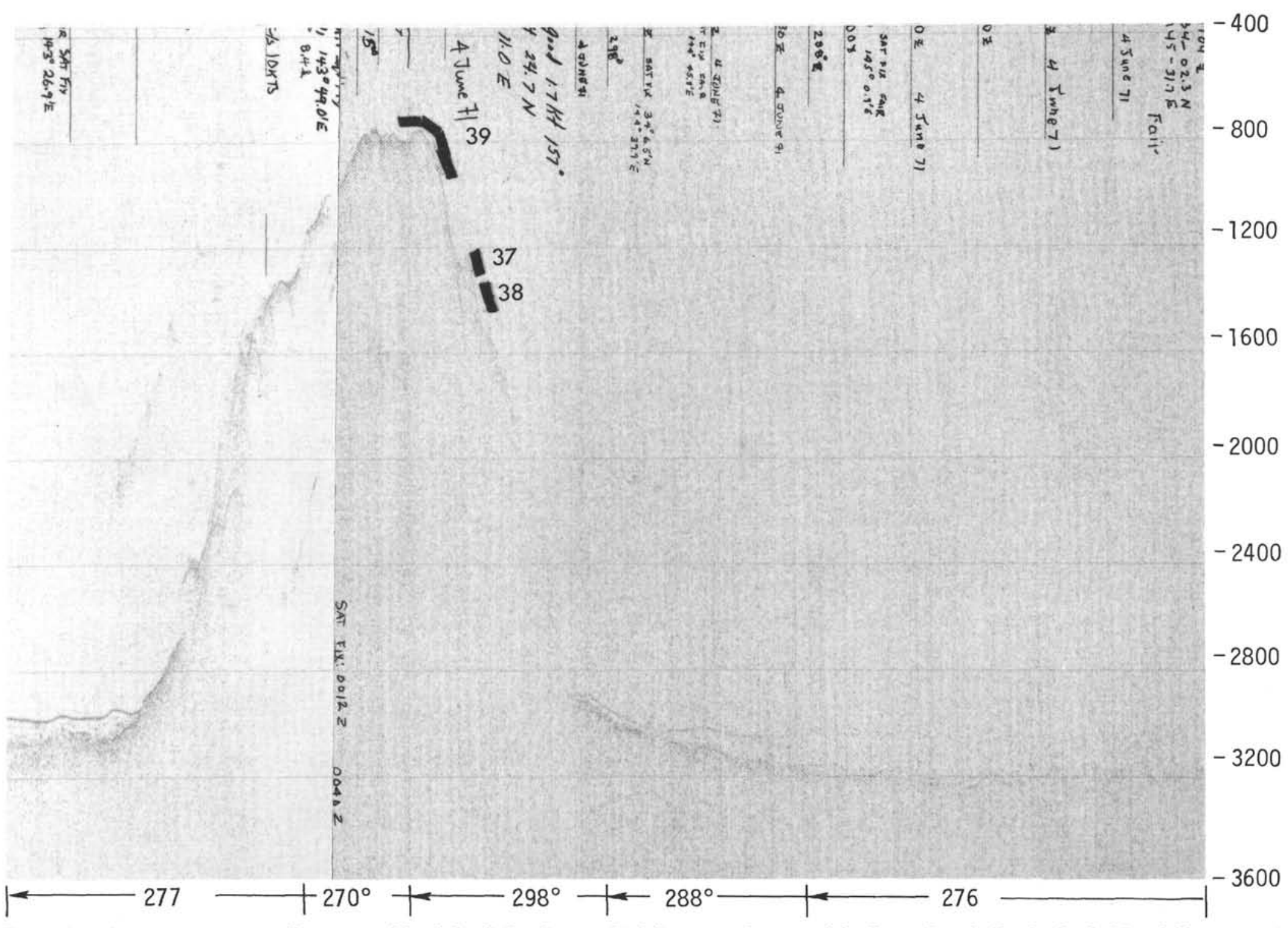

Figure 34. Composite seismic reflection profile of the Seiko Guyot which lie just to the east of the Japan Trench. Dredge hauls 37 and 39 recovered rudistid limestone of Cretaceous age. Dredge 38 recovered apparently ice-rafted andesite and pumice. 


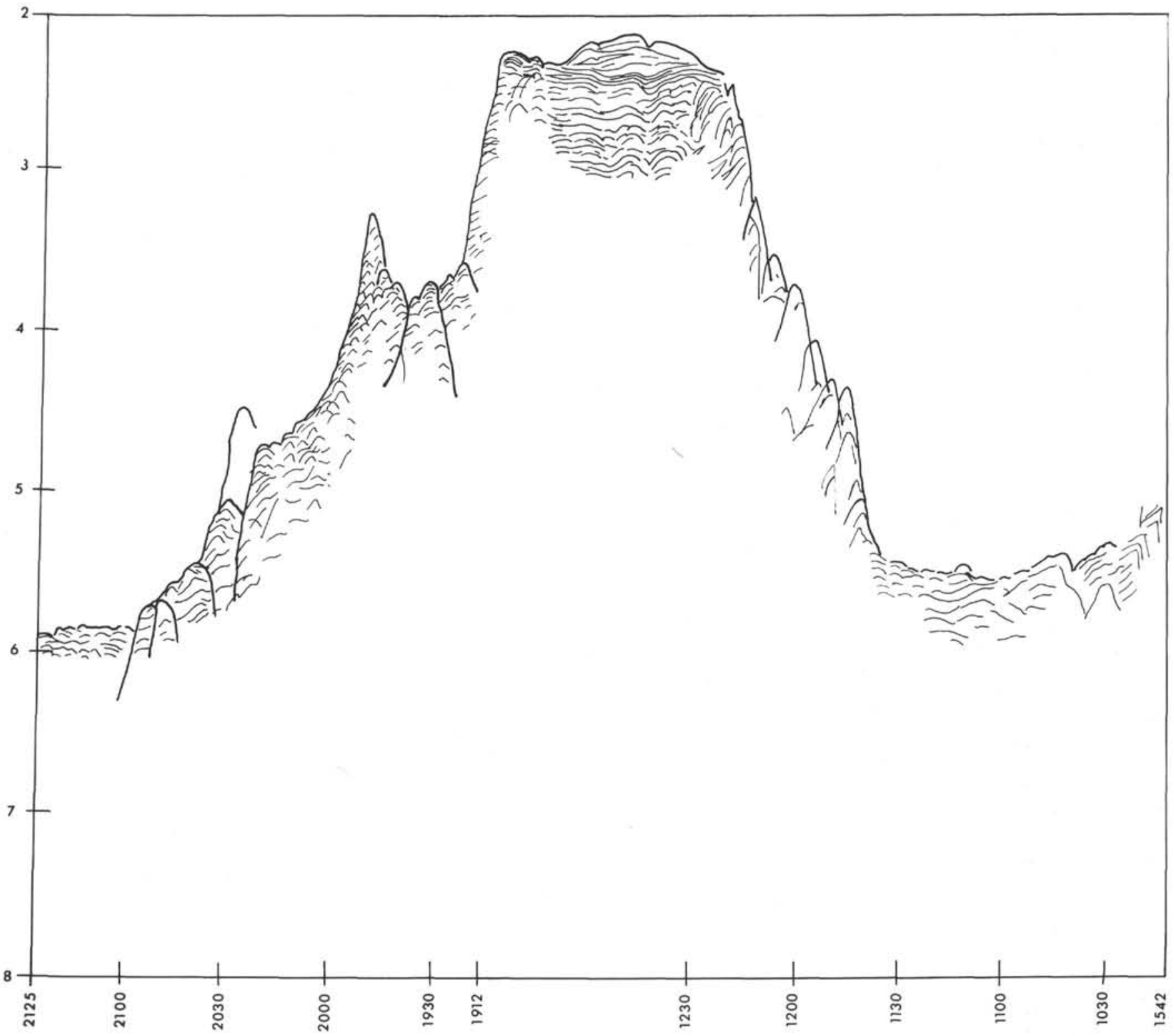

Figure 35. Line drawing of Navoceano Guyot showing transparent sediment cap and internal stratification within the more opaque deposits below the presumably pelagic cap.

basalts are late cappings on Galápagos volcanoes which are primarily tholeiitic (McBirney and Williams, 1969). Alkali olivine basalts and later differentiates, including trachytes, cap the predominantly tholeiitic basalt Hawaiian volcanoes (Macdonald, 1958b). Mildly alkalic and strongly alkalic series, one leading to trachyte, the other to phonolite, are found side by side on Tahiti (McBirney and Aoki, 1968). It is unlikely that dredging will ever be able to sample a seamount as thoroughly as any of these island groups have been sampled. Nevertheless, with one or two exceptions, the dredge hauls described from the guyots of the Pacific have striking regional consistency. Since most were dredged at or near the tops of the guyots, the last stages of volcanism have been preferentially sampled, insuring recovery of the most diagnostic rocks for the purposes of defining petrographic provinces. To the extent that these few dredge hauls may be diagnostic, three petrographic provinces seem indicated for the Pacific guyots; a tholeiitic province in at least part of the Mid-Pacific Mountains, an alkalic province in the Geisha guyots, and a strongly alkalic province in the group. The most striking contrast is evident between the pigeonitic basalts of the Mid-Pacific Mountains and the limburgites of the Wake guyots. These two suites have not been reported coexisting in abundance in the exposed portions of any volcanic islands, and thus they provide the major distinction allowing definition of submerged western Pacific volcanic petrographic provinces.

Cretaceous reef fossils have been dredged from two of these petrographic provinces, the Mid-Pacific Mountains and the Geisha guyots, indicating probable approximate synchronaiety of volcanism for both groups. The guyots have only thin cappings of reef limestone, and thus did not become atolls before reef extinction. Reef extinction thus did not long follow volcanism. The Wake Guyots, from 
TABLE 1

Age, Lithology and Location of ARIES V Dredge Hauls

\begin{tabular}{|c|c|c|c|c|c|c|c|}
\hline Dredge & Position & $\begin{array}{l}\text { Depth } \\
(\mathrm{m})\end{array}$ & & Lithology & Age & Fossils & Location \\
\hline 1 & $\begin{array}{r}17^{\circ} 28.4^{\prime} \mathrm{N} \\
175^{\circ} 14.0^{\prime} \mathrm{W} \\
\end{array}$ & $\begin{array}{l}3543 \\
4142 \\
\end{array}$ & a) & Foraminiferal-nannofossil ooze & Upper Pliocene-Rec. & Planktonic foraminifera and coccoliths & $\begin{array}{l}\text { Escarpment near } \\
\text { Murray Guyot }\end{array}$ \\
\hline 2 & $\begin{array}{r}17^{\circ} 47.2^{\prime} \mathrm{N} \\
176^{\circ} 05.1^{\prime} \mathrm{W}\end{array}$ & $\begin{array}{l}2400 \\
2415\end{array}$ & a) & Foraminiferal-nannofossil ooze & Upper Pliocene-Rec. & Planktonic foraminifera and coccoliths & Renard Guyot \\
\hline \multirow[t]{2}{*}{3} & \multirow{2}{*}{$\begin{array}{r}17^{\circ} 47.2^{\prime} \mathrm{N} \\
176^{\circ} 05.1^{\prime} \mathrm{W}\end{array}$} & \multirow{2}{*}{$\begin{array}{l}2250 \\
2730\end{array}$} & a) & Nannofossil-foraminiferal ooze & Upper Pliocene-Rec. & \multicolumn{2}{|l|}{ Planktonic foraminifera and coccoliths } \\
\hline & & & b) & $\begin{array}{l}\text { Indurated pelagic chalks and } \\
\text { phosphorites }\end{array}$ & Lower Eocene & \multicolumn{2}{|l|}{$\begin{array}{l}\text { Planktonic foraminifera: } G l \text {. cf. aragonensis, Acarinina bul- } \\
\text { brookii, A. pseudotopilensis Gl. centralis, Gl. lehneri }\end{array}$} \\
\hline 4 & $\begin{array}{r}17^{\circ} 04.8^{\prime} \mathrm{N} \\
177^{\circ} 18.7^{\prime} \mathrm{W}\end{array}$ & $\begin{array}{l}2330 \\
2425\end{array}$ & a) & Foraminiferal-nannofossil ooze & Upper Pliocene-Rec. & Planktonic foraminifera and coccoliths & $\begin{array}{l}\text { Cape Johnson } \\
\text { Guyot }\end{array}$ \\
\hline \multirow[t]{2}{*}{5} & \multirow{2}{*}{$\begin{array}{r}17^{\circ} 04.8^{\prime} \mathrm{N} \\
177^{\circ} 08.7^{\prime} \mathrm{W}\end{array}$} & \multirow{2}{*}{$\begin{array}{l}2126 \\
2130\end{array}$} & a) 1 & Nannofossil-foraminiferal ooze & Upper Pliocene-Rec. & Planktonic foraminifera and coccoliths & \multirow{2}{*}{$\begin{array}{l}\text { Cape Johnson } \\
\text { Guyot }\end{array}$} \\
\hline & & & b) & $\begin{array}{l}\text { White indurated foraminiferal chalks } \\
\text { and phosphorites manganese coated }\end{array}$ & Middle Eocene & $\begin{array}{l}\text { Planktonic foraminifera: } T \text {. topilensis, } T \text {. rohri Orb. beck- } \\
\text { manni, Gl. centralis, Gl. crassata, Glta unicava, Glta howeii }\end{array}$ & \\
\hline \multirow[t]{4}{*}{7} & \multirow{4}{*}{$\begin{array}{r}19^{\circ} 14.5^{\prime} \mathrm{N} \\
179^{\circ} 33.4^{\prime} \mathrm{W}\end{array}$} & \multirow{4}{*}{$\begin{array}{l}3200 \\
4255\end{array}$} & a) 1 & Foraminiferal-nannofossil ooze & Upper Pliocene-Rec. & & \multirow[t]{4}{*}{ Shepard Guyot } \\
\hline & & & b) & $\begin{array}{l}\text { White chalky phosphorites manganese } \\
\text { coated }\end{array}$ & Cenomanian-Turonian & $\begin{array}{l}\text { Planktonic foraminifera: } P \text {. cf. helvetica, Globigerinelloides } \\
\text { sp.; Hedbergella } \mathrm{sp} \text {. }\end{array}$ & \\
\hline & & & c) & $\begin{array}{l}\text { Porous limestones and bioclastic } \\
\text { calcarinites }\end{array}$ & Lower(?) Cretaceous & Red algae (Solenopora sp., Parachaetes sp.), corals, molluscs & \\
\hline & & & d) & Basalt and volcanic ash & & & \\
\hline \multirow[t]{4}{*}{9} & \multirow{4}{*}{$\begin{array}{r}19^{\circ} 19.6^{\prime} \mathrm{N} \\
176^{\circ} 45.4^{\prime} \mathrm{E}\end{array}$} & \multirow{4}{*}{$\begin{array}{l}3500 \\
3700\end{array}$} & a) 1 & Foraminiferal-nannofossil ooze & Upper Pliocene-Rec. & & \multirow[t]{4}{*}{ Jacqueline Guyot } \\
\hline & & & b) & $\begin{array}{l}\text { Pink porous lutitic phosphorites with } \\
\text { manganese crust }\end{array}$ & Cretaceous & & \\
\hline & & & c) & $\begin{array}{l}\text { Porous coquina limestones and } \\
\text { phosphorites }\end{array}$ & Cretaceous & Echinoid plates, Solenopora sp., corals, molluscs & \\
\hline & & & d) & Basalt and volcanic ash & & & \\
\hline \multirow[t]{5}{*}{10} & \multirow{5}{*}{$\begin{aligned} 19^{\circ} 19.0^{\prime} \mathrm{N} \\
176^{\circ} 44.7^{\prime} \mathrm{E}\end{aligned}$} & \multirow{5}{*}{$\begin{array}{l}2057 \\
225 i\end{array}$} & a) & Foraminiferal-nannofossil ooze & Upper Pliocene-Rec. & & \multirow[t]{5}{*}{ Jacqueline Guyot } \\
\hline & & & b) & $\begin{array}{l}\text { Cream chalky phosphorites with man- } \\
\text { ganese crusts }\end{array}$ & Cenomanian-Turonian & $\begin{array}{l}\text { Planktonic foraminifera: Clavihed. simplex, P. helvetica, } \\
R \text {. cf. cushmani }\end{array}$ & \\
\hline & & & c) & $\begin{array}{l}\text { White coarse-grained bioclastic } \\
\text { calcarenites }\end{array}$ & Lower(?) Cretaceous & Algae, molluscs, echinoids & \\
\hline & & & d) & $\begin{array}{l}\text { Rudistid phosphorites manganese } \\
\text { coated with extensive burrowing }\end{array}$ & Lower Cretaceous & $\begin{array}{l}\text { Red algae, echinoids, molluscs (Caprinids), planktonic } \\
\text { foraminifera (Globotruncana spp.) }\end{array}$ & \\
\hline & & & e) & Volcanic ash & & & \\
\hline \multirow[t]{3}{*}{12} & \multirow{3}{*}{$\begin{array}{r}20^{\circ} 44.2^{\prime} \mathrm{N} \\
173^{\circ} 27.2^{\prime} \mathrm{E}\end{array}$} & \multirow{3}{*}{$\begin{array}{l}1937 \\
2000\end{array}$} & a) & Foraminiferal-nannofossil ooze & Upper Pliocene-Rec. & & \multirow[t]{3}{*}{ Menard Guyot } \\
\hline & & & b) & $\begin{array}{l}\text { Foraminiferal chalky phosphorites } \\
\text { manganese coated }\end{array}$ & Cenomanian-Turonian & $\begin{array}{l}\text { Planktonic foraminifera: Hedbergella sp., Rotalipora sp., } \\
\text { Heterohelix sp. }\end{array}$ & \\
\hline & & & c) & $\begin{array}{l}\text { Brownish rudistid phosphorites } \\
\text { manganese coated. }\end{array}$ & Albian-Cenomanian & Molluscs (Caprinids), algae, echinoids & \\
\hline \multirow[t]{2}{*}{15} & \multirow{2}{*}{$\begin{array}{r}20^{\circ} 47.3^{\prime} \mathrm{N} \\
172^{\circ} 20.4^{\prime} \mathrm{E}\end{array}$} & 1421 & a) & Foraminiferal-nannofossil ooze & Upper Pliocene-Rec. & & Menard Guyot \\
\hline & & 1738 & b) & $\begin{array}{l}\text { Bioclastic calcarenites partly } \\
\text { phosphatized }\end{array}$ & Cretaceous & $\begin{array}{l}\text { Stromatoporoids, molluses, red algae (Solenopora sp., } \\
\text { benthonic foraminifera }\end{array}$ & \\
\hline
\end{tabular}




\begin{tabular}{|c|c|c|c|c|c|c|c|}
\hline 16 & $\begin{array}{r}21^{\circ} 33.3^{\prime} \mathrm{N} \\
173^{\circ} 52.0^{\prime} \mathrm{E}\end{array}$ & $\begin{array}{l}5316 \\
5400\end{array}$ & \multicolumn{4}{|c|}{ a) Red and brown clays } & $\begin{array}{l}\text { Deep-sea } \\
\text { escarpment }\end{array}$ \\
\hline \multirow[t]{2}{*}{19} & \multirow{2}{*}{$\begin{array}{l}21^{\circ} 09.0^{\prime} \mathrm{N} \\
163^{\circ} 22.04^{\prime} \mathrm{E}\end{array}$} & \multirow{2}{*}{$\begin{array}{l}1485 \\
2630\end{array}$} & a) & Breccias and volcanic tuffs & Middle Eocene & Tr. cf. topilensis, Gl.ta howeii, Gl. centralis & \multirow[t]{2}{*}{ Wilde Guyot } \\
\hline & & & b) & $\begin{array}{l}\text { Indurated foraminiferal chalks parti- } \\
\text { ally phosphatized }\end{array}$ & Middle Eocene & $T r$. cf. topilensis, Globigerapsis $\mathrm{cf}$. index, Gl. cf. centralis & \\
\hline 20 & $\begin{array}{r}21^{\circ} 09.6^{\prime} \mathrm{N} \\
163^{\circ} 08.8^{\prime} \mathrm{E}\end{array}$ & $\begin{array}{l}1386 \\
1453\end{array}$ & a) & $\begin{array}{l}\text { Nannofossil-foraminiferal chalks and } \\
\text { lutitic phosphorites with iron- } \\
\text { manganese crusts }\end{array}$ & Middle-upper Eocene & $\begin{array}{l}\text { Gl. centralis, Gl. cf. cerroazulensis, Gl.psis kugleri, Gl. } \\
\text { linaperta, Hantkenina }\end{array}$ & Wilde Guyot \\
\hline \multirow[t]{2}{*}{21} & \multirow[t]{2}{*}{$\begin{array}{r}21^{\circ} 42.78^{\prime} \mathrm{N} \\
161^{\circ} 52.66^{\prime} \mathrm{E}\end{array}$} & \multirow[t]{2}{*}{$\begin{array}{l}1535 \\
2050\end{array}$} & a) & $\begin{array}{l}\text { Volcanic breccia with fine-grained } \\
\text { phosphatic matrix }\end{array}$ & Eocene & Planktonic foraminifera & \multirow[t]{2}{*}{ Miami Guyot } \\
\hline & & & b) & $\begin{array}{l}\text { Pelagic lutitic foraminiferal } \\
\text { phosphorites }\end{array}$ & Middle Eocene & Planktonic foraminifera & \\
\hline \multirow[t]{2}{*}{22} & \multirow[t]{2}{*}{$\begin{array}{r}21^{\circ} 29.0^{\prime} \mathrm{N} \\
159^{\circ} 37.5^{\prime} \mathrm{E}\end{array}$} & \multirow[t]{2}{*}{$\begin{array}{l}1640 \\
2005\end{array}$} & a) & $\begin{array}{l}\text { Volcanic breccia with fine-grained } \\
\text { phosphatic matrix }\end{array}$ & Eocene & Planktonic foraminifera & \multirow[t]{2}{*}{ Lamont Guyot } \\
\hline & & & b) & $\begin{array}{l}\text { Porous indurated pelagic foraminiferal } \\
\text { chalks, partly phosphatized }\end{array}$ & Middle Eocene & Planktonic foraminifera & \\
\hline \multirow[t]{3}{*}{23} & \multirow[t]{3}{*}{$\begin{array}{r}21^{\circ} 29.0^{\prime} \mathrm{N} \\
159^{\circ} 32.3^{\prime} \mathrm{E}\end{array}$} & \multirow[t]{3}{*}{$\begin{array}{l}1215 \\
1275\end{array}$} & a) & $\begin{array}{l}\text { Porous indurates pelagic chalky } \\
\text { phosphorites }\end{array}$ & Eocene & Foraminifera and coccoliths & \multirow[t]{3}{*}{ Lamont Guyot } \\
\hline & & & b) & $\begin{array}{l}\text { Volcanic tuffs breccia with phosphat- } \\
\text { ized foraminiferal chalks }\end{array}$ & Middle-upper Eocene & Poorly preserved foraminifera & \\
\hline & & & c) & Basalt fragments & & & \\
\hline \multirow[t]{2}{*}{24} & \multirow[t]{2}{*}{$\begin{array}{r}21^{\circ} 28.8^{\prime} \mathrm{N} \\
159^{\circ} 14.9^{\prime} \mathrm{E}\end{array}$} & \multirow[t]{2}{*}{$\begin{array}{l}1499 \\
1999\end{array}$} & a) & $\begin{array}{l}\text { White indurated pelagic phosphatized } \\
\text { chalks }\end{array}$ & Eocene & Poorly preserved foraminifera & \multirow[t]{2}{*}{ Lamont Guyot } \\
\hline & & & b) & Volcanic tuffs & & 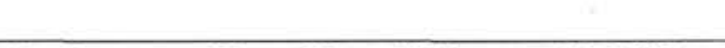 & \\
\hline \multirow[t]{2}{*}{25} & \multirow[t]{2}{*}{$\begin{array}{r}23^{\circ} 42.2^{\prime} \mathrm{N} \\
159^{\circ} 32.8^{\prime} \mathrm{E}\end{array}$} & \multirow[t]{2}{*}{$\begin{array}{l}2595 \\
3200\end{array}$} & a) & $\begin{array}{l}\text { White and brownish porous indurated } \\
\text { lutitic phosphorites coated by manga- } \\
\text { nese layers. }\end{array}$ & Middle Eocene & $\begin{array}{l}\text { Poorly preserved foraminifera: } G l \text {. linaperta, } H \text {. cf. liebus, } \\
H \text {. cf. alabamensis }\end{array}$ & \multirow[t]{2}{*}{ Scripps Guyot } \\
\hline & & & b) & Basalt fragments and tuffs & & & \\
\hline \multirow[t]{3}{*}{26} & \multirow[t]{3}{*}{$\begin{array}{r}23^{\circ} 48.9^{\prime} \mathrm{N} \\
159^{\circ} 26.2^{\prime} \mathrm{E}\end{array}$} & \multirow[t]{3}{*}{$\begin{array}{l}1767 \\
2004\end{array}$} & a) & $\begin{array}{l}\text { White porous indurated pelagic lutitic } \\
\text { phosphorites }\end{array}$ & Lower Eocene & Poorly preserved foraminifera and coccoliths & Scripps Guyot \\
\hline & & & b) & Phosphatized volcanic breccias & Eocene & Foraminifera and coccoliths & \\
\hline & & & c) & Basalt fragments & & & \\
\hline 27 & $\begin{array}{r}24^{\circ} 05.0^{\prime} \mathrm{N} \\
159^{\circ} 27.1^{\prime} \mathrm{E}\end{array}$ & $\begin{array}{l}3597 \\
4129\end{array}$ & a) & $\begin{array}{l}\text { White and brownish foramiferal chalky } \\
\text { phosphoritic cobbles }\end{array}$ & Middle-upper Eocene & Poorly preserved foraminifera & Scripps Guyot \\
\hline & & & b) & Porous phosphorites manganese coated & Cretaceous & Ghosts of Globotruncana sp. & \\
\hline 28 & $\begin{array}{r}30^{\circ} 40.0^{\prime} \mathrm{N} \\
158^{\circ} 416^{\prime} \mathrm{F}\end{array}$ & $\begin{array}{l}2067 \\
4808\end{array}$ & a) & Radiolarian ooze & & & Flank Shatsky \\
\hline & & & b) & Altered basalt covered by manganese & & & Plateau \\
\hline 29 & $\begin{aligned} 29^{\circ} 28.9^{\prime} \mathrm{N} \\
153^{\circ} 20.2^{\prime} \mathrm{E}\end{aligned}$ & $\begin{array}{l}2050 \\
2563\end{array}$ & a) & $\begin{array}{l}\text { White porous partially phosphatized } \\
\text { chalks and interbedded volcanic ash }\end{array}$ & Middle Eocene & $\begin{array}{l}\text { Rich planktonic foraminifera: } T \text { r. topilensis, Hantkenina } \\
\text { spp., Gl. cf. centralis }\end{array}$ & Makarov Guyot \\
\hline & & & b) & Phosphatized volcanic breccias & Upper Cretaceous & Planktonic foraminifera: Globotruncana sp. & \\
\hline & & & c) & Porous bioclastic arenitic phosphorites & Cenomanian-Turonian & $\begin{array}{l}\text { Planktonic foraminifera, echinoid plates, skeletal fish } \\
\text { fragments, molluscs }\end{array}$ & \\
\hline 30 & $\begin{aligned} 29^{\circ} 31.3^{\prime} \mathrm{N} \\
153^{\circ} 24.3^{\prime} \mathrm{E}\end{aligned}$ & $\begin{array}{l}2020 \\
2300\end{array}$ & a) & $\begin{array}{l}\text { Porous bioclastic calcarenites and are- } \\
\text { nitic phosphorites }\end{array}$ & Cenomanian-Senonian & $\begin{array}{l}\text { Molluscs, skeletal fish fragments, benthonic foraminifera, } \\
\text { coccoliths, planktonic foraminifera (Rotalipora spp., } \\
\text { Globotruncana spp.) }\end{array}$ & Makarov Guyot \\
\hline
\end{tabular}


TABLE 1 -Continued

\begin{tabular}{|c|c|c|c|c|c|c|c|}
\hline Dredge & Position & $\begin{array}{l}\text { Depth } \\
(\mathrm{m})\end{array}$ & & Lithology & Age & Fossils & Location \\
\hline \multirow[t]{2}{*}{31} & $\begin{array}{r}31^{\circ} 33.4^{\prime} \mathrm{N} \\
151^{\circ} 13.3^{\prime} \mathrm{E}\end{array}$ & $\begin{array}{l}1742 \\
1875\end{array}$ & a) & Bioclastic calcarenites & Cenomanian-Senonian & $\begin{array}{l}\text { Molluscs, algae remains, echinoid plates and spines, colonial } \\
\text { corals, benthonic foraminifera (Orbitolina spp.), planktonic } \\
\text { foraminifera }\end{array}$ & Isakov Guyot \\
\hline & & & b) & $\begin{array}{l}\text { Porous rudistid limestones and } \\
\text { phosphorites }\end{array}$ & Lower Cretaceous & Caprinids & \\
\hline \multirow[t]{2}{*}{32} & $\begin{array}{r}32^{\circ} 00.3^{\prime} \mathrm{N} \\
149^{\circ} 17.0^{\prime} \mathrm{E}\end{array}$ & $\begin{array}{l}1529 \\
1958\end{array}$ & a) & $\begin{array}{l}\text { Porous foraminiferal phosphatized } \\
\text { chalks }\end{array}$ & Lower-middle Eocene & $\begin{array}{l}\text { Planktonic foraminifera: Truncorotaloides sp., Gl. cf. lina- } \\
\text { perta, Globonomalina sp. }\end{array}$ & $\begin{array}{l}\text { Thomas Washington } \\
\text { Guyot }\end{array}$ \\
\hline & & & b) & Porous rudist phosphorites & Cenomanian-Senonian & Mollusc fragments, Rudistids, echinoid plates & \\
\hline \multirow[t]{2}{*}{33} & $37^{\circ} 51.0^{\prime} \mathrm{N}$ & 1677 & a) & Phosphatized rudistid limestones & Cretaceous & Mollusc fragments, Rudistids (Caprinids) & Winterer Guyot \\
\hline & $148^{\circ} 17.8^{\prime} \mathrm{E}$ & 1974 & b) & Pelagic chalky phosphorites & Cenomanian-upper Cret. & $\begin{array}{l}\text { Planktonic foraminifera: Hedbergella spp., Rotalipora spp., } \\
\text { Clavihedbergella spp., Heterohelix sp., Gl. arca, Gl. ex gr. } \\
\text { lapparenti }\end{array}$ & \\
\hline 34 & $32^{\circ} 44.7^{\prime} \mathrm{N}$ & $\begin{array}{l}1874 \\
2208\end{array}$ & $\begin{array}{l}\text { a) } \\
\text { b) }\end{array}$ & $\begin{array}{l}\text { Porous bioclastic calcarenites } \\
\text { Volcanic ash }\end{array}$ & Cretaceous & Mollusc fragments, algal remains, echinoid plates & Winterer Guyot \\
\hline 36 & $\begin{array}{r}34^{\circ} 02.0^{\prime} \mathrm{N} \\
165^{\circ} 51.1^{\prime} \mathrm{E}\end{array}$ & $\begin{array}{l}3000 \\
3870\end{array}$ & $\begin{array}{l}\text { a) } \\
\text { b) }\end{array}$ & $\begin{array}{l}\text { Volcanic ash } \\
\text { Basalt fragments }\end{array}$ & & & Maiko Seamount \\
\hline 37 & $\begin{array}{r}34^{\circ} 13.2^{\prime} \mathrm{N} \\
144^{\circ} 11.11^{\prime} \mathrm{E}\end{array}$ & $\begin{array}{l}2080 \\
3000\end{array}$ & $\begin{array}{l}\text { a) } \\
\text { b) }\end{array}$ & $\begin{array}{l}\text { Bioclastic calcarenites } \\
\text { White to pink porous chalky } \\
\text { phosphorites }\end{array}$ & $\begin{array}{l}\text { Cretaceous } \\
\text { Upper Cretaceous }\end{array}$ & $\begin{array}{l}\text { Molluscs, Rudistids, algal remains } \\
\text { Planktonic foraminifera: Globotruncana ex gr. lapparenti }\end{array}$ & Eiko Seamount \\
\hline 39 & $\begin{aligned} 34^{\circ} 14.6^{\prime} \mathrm{N} \\
143^{\circ} 50.9^{\prime} \mathrm{E}\end{aligned}$ & $\begin{array}{l}2000 \\
2500\end{array}$ & a) & $\begin{array}{l}\text { Porous bioclastic calcarenites and } \\
\text { dense calcilutites }\end{array}$ & Cretaceous & Mollusc fragments, colonial corals, Rudistids & Seiko Seamount \\
\hline
\end{tabular}




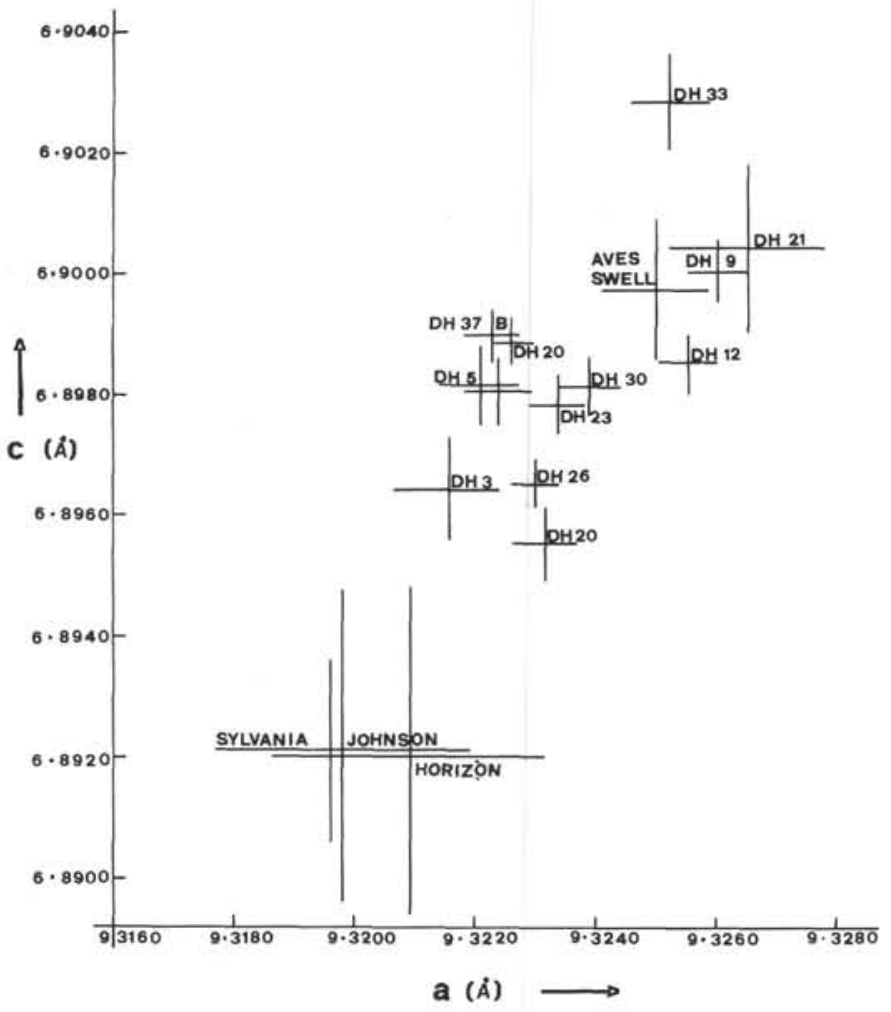

Figure 36. X-ray diffraction analyses of phosphorites, values of $\mathrm{C}$ vs. A for phosphorites from 13 western Pacific guyots dredged during ARIES $V$ and samples from four other locations (analyzed by Hermelin).

which no reef materials were dredged, may be younger than the Mid-Pacific and Geisha guyots (Upper Cretaceous foraminifera are the oldest fossils dredged from any of them). In the next section of this chapter, relative ages of the guyots and the underlying oceanic crust are discussed. From that discussion, it can be concluded that the tholeiitic volcanoes of the Mid-Pacific Mountains built upon crust probably 10-40 million years old; the alkalic series rocks of the Geisha guyots upon crust 50 million years old; and the strongly alkalic limburgites and related rocks of the Wake Group upon crust at least 90-100 million years old (if they were truncated at the same time as the Mid-Pacific Mountains and Geisha guyots) and possibly 130 million years old (if they are late Cretaceous or Paleogene in age as argued in the next section of this chapter).

Identification of roughly contemporaneous petrographic provinces for Pacific Cretaceous guyots allows comparison with the distribution of petrographic provinces today. McBirney (1967) and McBirney and Gass (1967) have attempted to relate the chemistry, and, to some extent, the petrography of volcanic rocks from recently active islands to distance from oceanic spreading centers. Using the Niggli $q z$ index as a semi-quantitative estimate of the degree of silica saturation and undersaturation of extreme late differentiates-soda rhyolites, trachytes, and phonolites, they were able to show that a large number of islands in the Atlantic and Pacific show a steady decrease in degree of silica saturation of these late differentiates with distance from rise crests. Briefly summarized, tholeiitic series erupt on islands near ocean rise systems and have late differentiates with marked silica enrichment. Alkali basalts are proportionally more abundant further away from rise crests, and produce trachytes (or quartz trachytes) barefly saturated or just undersaturated in silica. At great distances from rise crests, volcanoes produce strongly undersaturated suites (including limburgites) that lead to phonolitic differentiates.

The theoretical justification for this observation is still highly speculative and will not be considered here. Further, though the observation apparently covers many island groups in the Atlantic and Pacific, anomalies like Hawaii, predominantly tholeiitic basalt, are not easily explained. The analysis of McBirney and Gass (1967) applies to extreme late differentiates only, although the earlier members of the rock series are implicit in their observation. The igneous rocks recovered from the Pacific guyots are only rarely the extreme late differentiates; generally they are early or intermediate members of differentiation series. Comparison to present day volcanoes must then largely be made on the basis of rocks preceding trachytes or phonolites in differentiation sequences.

McBirney and Williams (1969) have called attention to the predominance of olivine-plagioclase tholeiitic basalts on volcanic islands such as the Galápagos, Easter Island (Bandy, 1937) and Iceland, that build at or near rise crests and produce pigeonite-bearing intermediate differentiates and late differentiates with a large degree of quartz enrichment. Evidence presented here indicates that olivine-plagioclase tholeiitic basalts and pigeonite-bearing intermediate volcanics formed Cretaceous seamounts and islands in the Mid-Pacific Mountains on young oceanic crust. Smith and Chubb (1927) and McBirney and Aoki (1968) have noted the abundance of titanaugite-rich rocks-ankaramites and limburgites-in the strongly alkalic island occurrences of Tahiti and the Australs, island groups where phonolite is also found. These islands appear to have built on crust 90 to 100 million years old or older. Similar age relations and similar rocks characterize guyots of the wake group. Finally, the intermediate character of the rocks from the Geisha guyots agrees with the suggestion that rocks of this type should occur on volcanoes supported by crust intermediate in age between that supporting tholeiitic and strongly alkalic volcanoes. On this comparative (and approximate) petrographic basis, the pattern of increasing alkalinity and degree of silica undersaturation with distance from rise crests (age of supporting oceanic crust) shown by rock series of present-day volcanoes is confirmed by the Pacific guyots.

\section{DATE OF THE SUBMERGENCE}

Rudists from the reef limestones supplied the oldest ages discovered among the carbonates (Figures 37, 38). The rudists from Isakov Guyot indicate an Albian to Cenomanian age, which is consistent with the Cenomanian to Senonian range of the foraminifera trapped in the pores of the limestone. Winterer and Eiko guyots have rudists of Albian age; Cenomanian and Upper Cretaceous chalk is assuciated with Winterer Guyot. Jacqueline Guyot yielded reef limestone encompassing poorly preserved Cenomanian to Senonian rudists and a chalk with Cenomanian and 
B. C. HEEZEN, J. L. MATTHEWS, R. CATALANO, J. NATLAND, A. COOGAN, M. THARP, M. RAWSON

TABLE 2

Volcanic Rocks Dredged from Guyot, Seamounts, and Ridges, Northwest Pacific

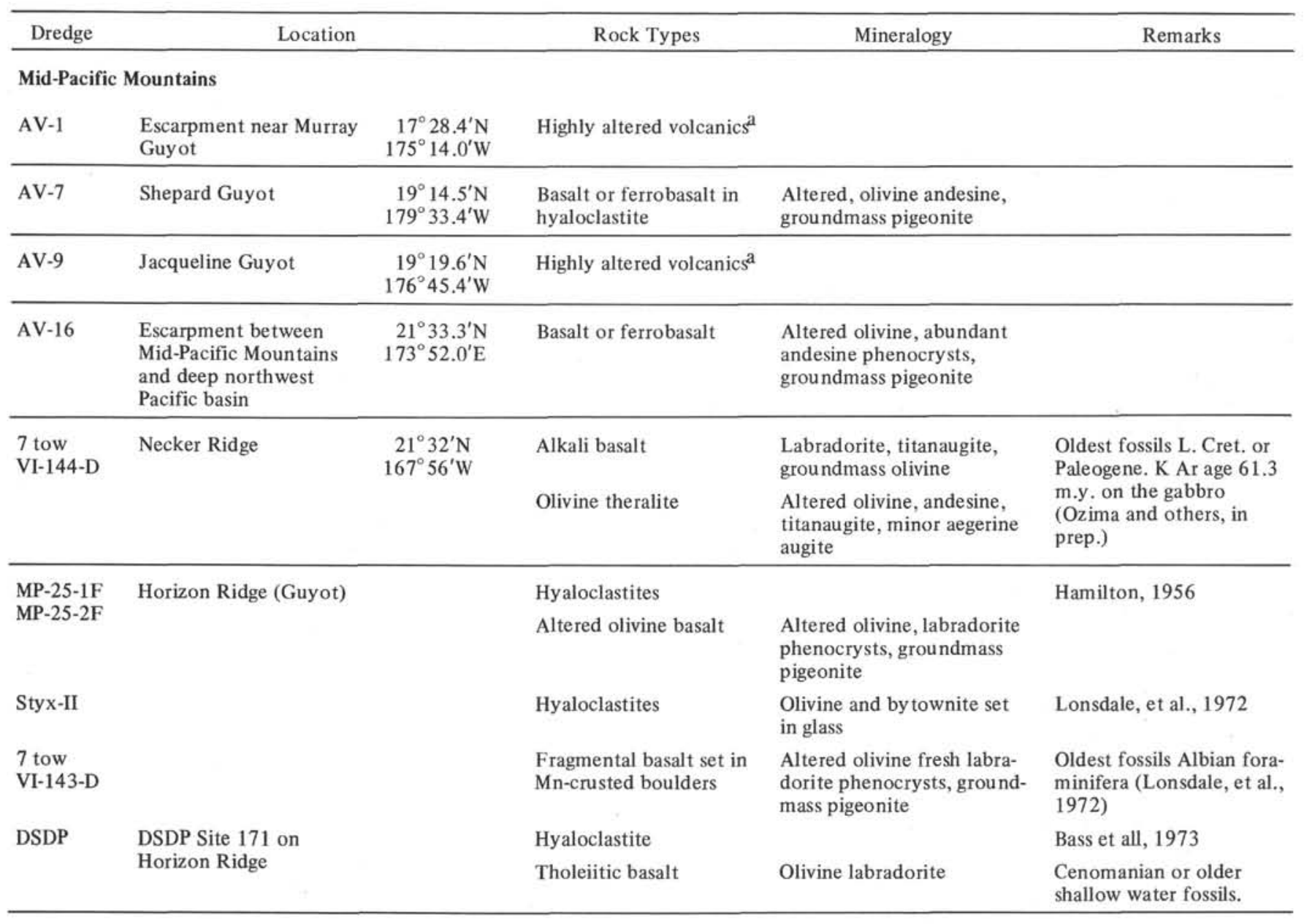

Wake Guyots

\begin{tabular}{|c|c|c|c|c|c|}
\hline AV-19 & Wilde Guyot & $\begin{array}{r}21^{\circ} 09.0^{\prime} \mathrm{N} \\
163^{\circ} 22.0^{\prime} \mathrm{E}\end{array}$ & Mugearite & $\begin{array}{l}\text { Oligoclase }\left(A_{21}\right) \text {; rare } \\
\text { nepheline }\end{array}$ & $\begin{array}{l}\text { Rounded, angular frag- } \\
\text { ments in chalk. Probably } \\
\text { erosional. }\end{array}$ \\
\hline \multirow[t]{2}{*}{ AV -20} & \multirow[t]{2}{*}{ Wilde Guyot } & \multirow{2}{*}{$\begin{array}{r}21^{\circ} 09.6^{\prime} \mathrm{N} \\
168^{\circ} 08.8^{\prime} \mathrm{E}\end{array}$} & Hyaloclastite $^{\mathrm{a}}$ & & \\
\hline & & & Altered picrite & $\begin{array}{l}\text { Altered olivene, pyroxene } \\
\text { phenocrysts, abundant } \\
\text { groundmass titanaugite }\end{array}$ & $\begin{array}{l}\text { Picrite fragments embed- } \\
\text { ded in Eocene chalk. }\end{array}$ \\
\hline AV-21 & Miami Guy ot & $\begin{array}{r}21^{\circ} 42.8^{\prime} \mathrm{N} \\
161^{\circ} 52.7^{\prime} \mathrm{E}\end{array}$ & Limburgite & $\begin{array}{l}\text { Altered olivine phenocrysts; } \\
\text { abundant groundmass } \\
\text { titanaugite }\end{array}$ & $\begin{array}{l}\text { Volcanics embedded in } \\
\text { Eocene chalk. }\end{array}$ \\
\hline AV-22 & Lamont Guyot & $\begin{array}{r}21^{\circ} 29.0^{\prime} \mathrm{N} \\
159^{\circ} 37.5^{\prime} \mathrm{E}\end{array}$ & Highly altered volcanics ${ }^{\mathrm{a}}$ & & $\begin{array}{l}\text { Volcanics embedded in } \\
\text { Eocene chalk. }\end{array}$ \\
\hline AV-23 & Lamont Guyot & $\begin{array}{r}21^{\circ} 29.0^{\prime} \mathrm{N} \\
159^{\circ} 32.3^{\prime} \mathrm{E}\end{array}$ & Olivine theralite & $\begin{array}{l}\text { Iddingsite after olivine, } 30 \% \text {; } \\
\text { minor biotite and analcime }\end{array}$ & $\begin{array}{l}\text { Rounded cobble, probably } \\
\text { erosional. K-Ar model age } \\
\text { of } 55 \mathrm{~m} . \mathrm{y} \text {. on sample not } \\
\text { examined by the authors } \\
\text { (Ozima and others, in } \\
\text { prep.) }\end{array}$ \\
\hline
\end{tabular}

\begin{tabular}{|c|c|c|c|}
\hline AV-24 & Lamont Guyot & $\begin{array}{r}21^{\circ} 28.8^{\prime} \mathrm{N} \\
159^{\circ} 14.9^{\prime} \mathrm{E}\end{array}$ & Highly altered volcanics ${ }^{a}$ \\
\hline
\end{tabular}


TABLE 2 - Continued

\begin{tabular}{|c|c|c|c|c|c|}
\hline Dredge & & & Rock Types & Mineralogy & Remarks \\
\hline \multicolumn{6}{|c|}{ Wake Guyots - Continued } \\
\hline AV -25 & Scripps Guyot & $23^{\circ} 42.2^{\prime} \mathrm{N}$ & Limburgite & $\begin{array}{l}\text { Titanaugite, kaersutite, } \\
\text { mepheline phenocrysts, } \\
\text { abundant groundmass } \\
\text { titanaugite, minor andesine }\end{array}$ & $\begin{array}{l}\text { K-Ar age of } 24.8 \mathrm{~m} . y . \\
\text { (Ozima and others, in } \\
\text { prep.) }\end{array}$ \\
\hline AV-26 & Scripps Guyot & $\begin{array}{r}23^{\circ} 48.9^{\prime} \mathrm{N} \\
159^{\circ} 26.2^{\prime} \mathrm{E}\end{array}$ & Hyaloclastite $^{\mathrm{a}}$ & & \\
\hline AV-27 & Scripps Guyot & $\begin{array}{r}24^{\circ} 05.0^{\prime} \mathrm{N} \\
159^{\circ} 27.1^{\prime} \mathrm{E}\end{array}$ & Limburgite & $\begin{array}{l}\text { Titanaugite, kaersutite, } \\
\text { nepheline phenocrysts, } \\
\text { abundant groundmass } \\
\text { titanaugite, minor andesine }\end{array}$ & \\
\hline AV -28 & Shatsky Plateau & $\begin{array}{r}30^{\circ} 28.9^{\prime} \mathrm{N} \\
158^{\circ} 20.2^{\prime} \mathrm{E}\end{array}$ & $\begin{array}{l}\text { Altered variolitic olivine } \\
\text { basalt }\end{array}$ & $\begin{array}{l}\text { Abundant secondary sanidine } \\
\text { replacing plagioclase }\end{array}$ & $\begin{array}{l}\text { Pillow lavas, submarine } \\
\text { extrusives }\end{array}$ \\
\hline
\end{tabular}

\section{Geisha Guyots}

\begin{tabular}{|c|c|c|c|c|c|}
\hline AV-29 & Makarov Guyot & $\begin{array}{r}29^{\circ} 28.9^{\prime} \mathrm{N} \\
153^{\circ} 20.2^{\prime} \mathrm{E}\end{array}$ & $\begin{array}{l}\text { Hyaloclastites with frag- } \\
\text { ments of nepheline basalt }\end{array}$ & $\begin{array}{l}\text { Altered olivine, abundant } \\
\text { titanaugite, lesser andesine }\end{array}$ & \\
\hline AV -30 & Makarov Guyot & $\begin{array}{r}29^{\circ} 31.3^{\prime} \mathrm{N} \\
153^{\circ} 24.3^{\prime} \mathrm{E}\end{array}$ & Benmoreite or trachy te & $\begin{array}{l}\text { Oligoclase, potash oligoclase, } \\
\text { anorthoclase }\end{array}$ & $\begin{array}{l}\mathrm{K} \text {-Ar age of } 94.2 \text { m.y. on } \\
\text { sample from this dredge } \\
\text { haul (Ozima and others, } \\
\text { in prep.) }\end{array}$ \\
\hline
\end{tabular}

\begin{tabular}{lrrll}
\hline AV-34 & Winterer Guyot & $\begin{array}{r}32^{\circ} 44.7^{\prime} \mathrm{N} \\
148^{\circ} 13.5^{\prime} \mathrm{E}\end{array}$ & Mudstone $^{\mathrm{a}}$ & \\
\hline AV-36 & Maiko Seamount & $\begin{array}{rlll}34^{\circ} 02.0^{\prime} \mathrm{N} \\
145^{\circ} 51.1^{\prime} \mathrm{E}\end{array}$ & $\begin{array}{l}\text { Hyaloclastite } \\
\text { Variolitic altered olivine } \\
\text { basalt, probably once } \\
\text { alkalic }\end{array}$ & $\begin{array}{l}\text { Iddingsite phenocrysts, } \\
\text { abundant groundmass idding- } \\
\text { site after olivine, plag. } \\
\text { replaced by secondary } \\
\text { K-feldspar }\end{array}$ \\
& & & Submarine eruptives \\
\end{tabular}

\begin{tabular}{|c|c|c|c|c|c|}
\hline AV-37 & Eiko Guyot & $\begin{array}{r}34^{\circ} 13.2^{\prime} \mathrm{N} \\
144^{\circ} 11.1^{\prime} \mathrm{E}\end{array}$ & $\begin{array}{l}\text { Mudstone with sand } \\
\text { interlayers, volcanic sand } \\
\text { grains }\end{array}$ & & \\
\hline AV -38 & Eiko Guyot & $\begin{array}{r}34^{\circ} 09.5^{\prime} \mathrm{N} \\
144^{\circ} 13.5^{\prime} \mathrm{E}\end{array}$ & $\begin{array}{l}\text { Hypersthene andesite } \\
\text { and pumice }\end{array}$ & $\begin{array}{l}\text { Labradorite, hypersthene, } \\
\text { augite phenocrysts, quartz } \\
\text { sanidine, albite in devitri- } \\
\text { fied mesostasis }\end{array}$ & Probably ice-rafted \\
\hline \multirow[t]{3}{*}{ AV -39} & \multirow[t]{3}{*}{ Seiko Guyot } & \multirow[t]{3}{*}{$\begin{array}{r}34^{\circ} 14.6^{\prime} \mathrm{N} \\
143^{\circ} 50.8^{\prime} \mathrm{E}\end{array}$} & Quartz trachy te & $\begin{array}{l}\text { Sanidine, potash oligoclase, } \\
\text { anorthoclase, minor quartz }\end{array}$ & \multirow{3}{*}{$\begin{array}{l}\text { All rocks texturally similar } \\
\text { with abundant magnetite. } \\
\text { Probably in situ. }\end{array}$} \\
\hline & & & Benmoreite & $\begin{array}{l}\text { Potash oligoclase } \\
\text { anorthoclase }\end{array}$ & \\
\hline & & & Mugearite & $\begin{array}{l}\text { Sodic andesine phenocrysts, } \\
\text { oligoclase microlites, potash } \\
\text { oligoclase }\end{array}$ & \\
\hline
\end{tabular}

\footnotetext{
a Thin sections not prepared.
}

Turonian foraminifera. Dredge hauls from Menard, Jacqueline, Scripps, Miami, Winterer, Thomas Washington, and Eiko guyots contained reef limestone, which in thin-section is indistinguishable from the Albian reef limestones of Winterer and Seiko guyots, but whose grain size is too small and the preservation too poor for the recognition of rudists. However, the dredge haul from Menard Guyot included a lutite with Cenomanian-Turonian foraminifera; several Cenomanian-Turonian foraminifera are included in the pores of the reef limestone from Makarov Guyot; the reef limestones from Jacqueline, Scripps, and
Thomas Washington guyots had entrapped foraminifera with a Cenomanian-Senonian age range; and the reef limestone from Winterer Guyot contains TuronianSenonian foraminifera, which leads us to suspect that all the reef limestones have an Albian-Cenomanian age. The pattern of Albian-Cenomanian reef deposition followed by Upper Cretaceous chalk deposition has been previously reported. Albian fossils were recovered from Horizon Ridge (Guyot) (Normark in Larson and Chase, 1972), and at DSDP Site 171, a considerable thickness of Upper Cretaceous chalk was penetrated before striking reef debris 


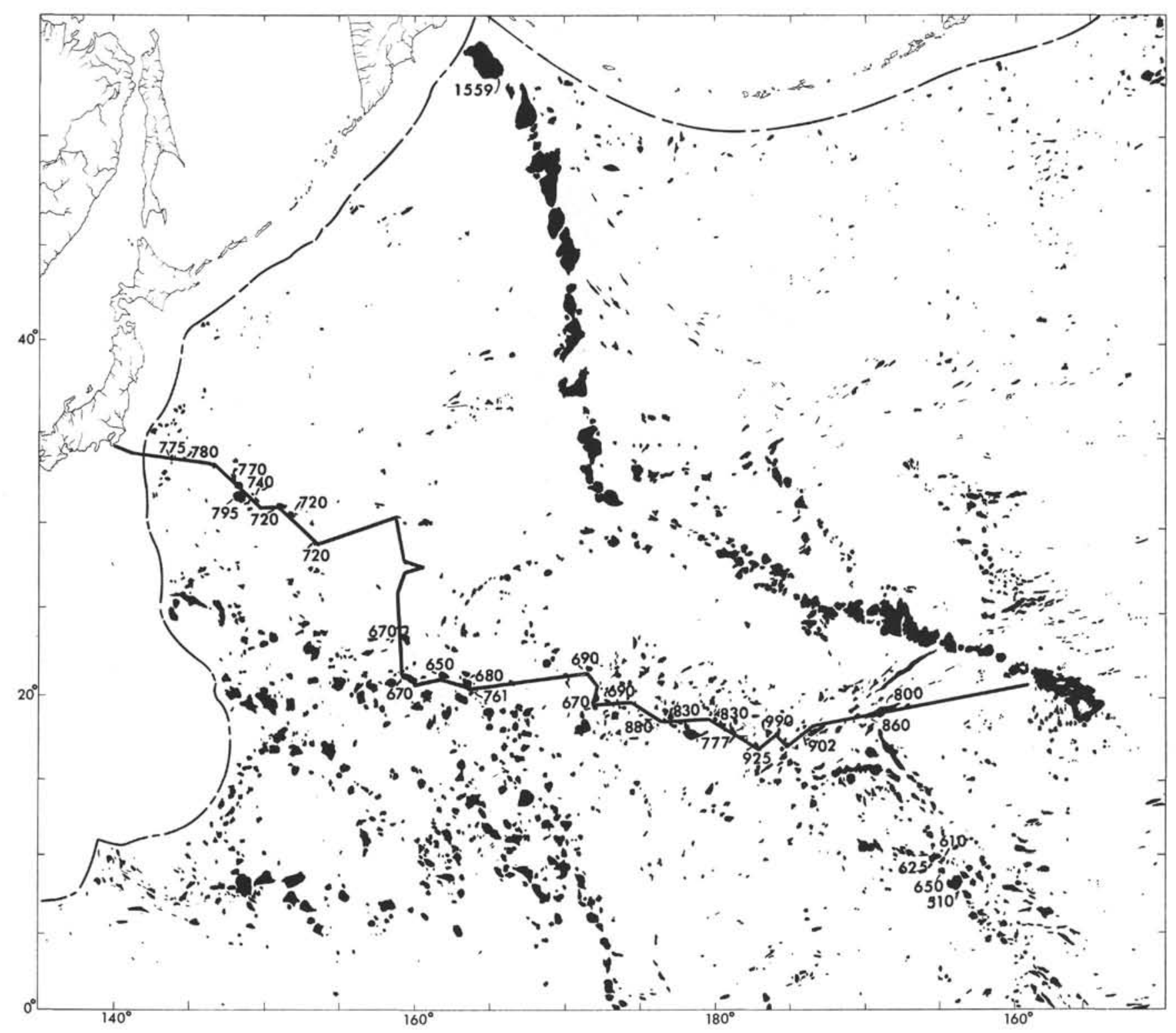

Figure 37. Depths of the break in slope of guyots dredged during ARIES V (in tau).

on this beveled ridge (Winterer et al., 1973). Hamilton (1956) reported Albian-Cenomanian invertebrates and Upper Cretaceous foraminifera from three guyots in the Mid-Pacific Mountains. Siseov Guyot, off the coast of Japan, yielded Upper Cretaceous gastropods. Thus, all the reefs of the Mid-Pacific mountains and the guyots off the coast of Japan may have simultaneously died off sometime during the Albian-Cenomanian. After a sufficient depth of water had covered the guyots, they became sites for the deposition of foraminiferal ooze. Pelagic deposition started in Cenomanian and may have continued without interruption to the end of the Cretaceous.

Hamilton (1956), in his discussion of the drowning of the sunken islands of the Mid-Pacific Mountains, concluded that the submergence may have been due to the local sinking of the ocean floor. that submergence caused the death of the reef-dwelling fauna of the Mid-Pacific
Mountains seems a valid conclusion. Expanding the argument to include the Geisha guyots, it is here proposed that a relatively rapid eustatic rise of sea level rather than local subsidence caused the death of the reef communities and the submergence of the reefs and islands. The breadth of the area involved is great, stretching from Horizon Ridge (Guyot) $\left(170^{\circ} \mathrm{W}\right)$ in the east to Eiko Guyot $\left(150^{\circ} \mathrm{E}\right)$ (Figure 1) in the west, and includes a considerable portion of the Pacific plate. Contemporary tectonic concepts provide that with time the oceanic crust slowly founders. They also suggest mechanisms that cause sea level to fluctuate as, for instance, when the overall rate of mid-oceanic axial accretion changes (Sclater et al., 1971) or when the configuration of the ridge changes, causing changes in the total volume of the mid-oceanic ridge, and consequently a change in the volume of water displaced (Menard and Smith, 1966; Figure 10). Other mechanisms 


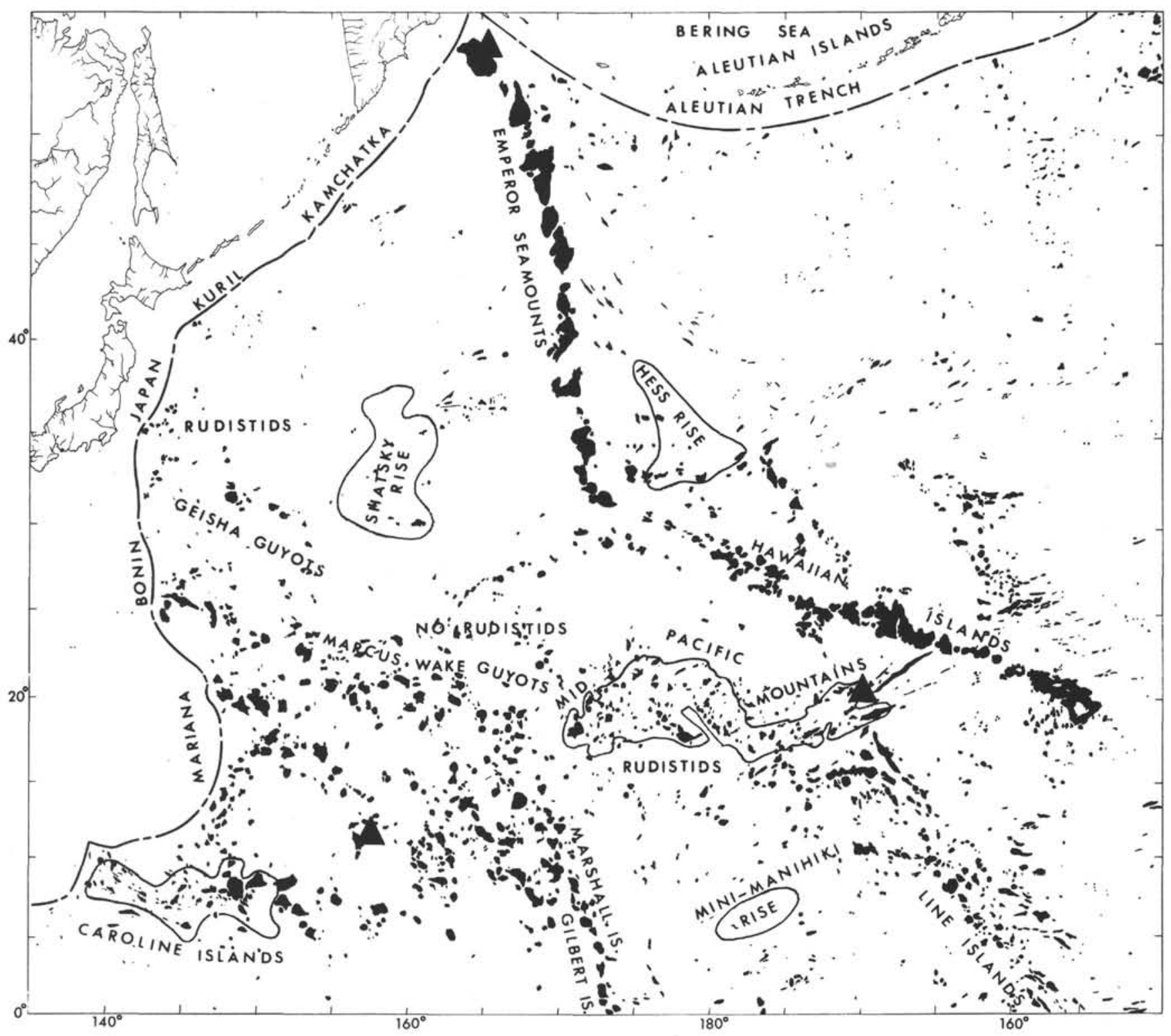

Dorilling sites

Figure 38. Presence of rudists in the guyot groups of the western Pacific.

have been proposed that correlate the fluctuation of sea level with tectonics (Hess, 1946) and climatic change (Wanless and Shepard, 1936).

Douglas, Moullade, and Nairn (1973), using paleontological arguments, recognize a world wide rise of Cretaceous sea level that began with a major pulse in the Albian and climaxed near the end of the Turonian. Larson and Pitman (1972), tracing rates of spreading by magnetic lineations, propose a rapid increase of spreading 110 to 95 million years ago in the Pacific and Atlantic oceans, which should have caused a dramatic rise of sea level. The rapid rise of sea level suggested by both geophysical and paleontological data started 110 to 100 million years ago and apparently resulted in the submergence of the reef faunas of the Mid-Pacific Mountains and the Geisha guyots some time during the Albian. The volcanic pedestals of the guyots are, of course, older than the reefs that cap them and are evidently not all the same age (Figure 39 ). In addition to a natural reluctance to propose the simultaneous eruption of all volcanoes throughout a huge ocean basin, we have the impression that some of the guyots of the eastern Mid-Pacific had accumulated a considerable thickness of sediments before their submergence and perhaps had an atoll-like existence prior to drowning, while the Geisha guyots, which appear to lack such a cap, seem to have briefly been carbonate banks before their submergence.

The date of submergence of the Wake guyots is less certain. Shallow-water reef material was not recovered from any guyot in this group. Some of the Eocene pelagic carbonates include volcanic clasts. Although further dredging may alter the picture, present evidence suggests that the middle Cretaceous rudistid reefs were not present on the Wake group guyots and that these guyots are much younger than the other guyots dredged. The dredging of 


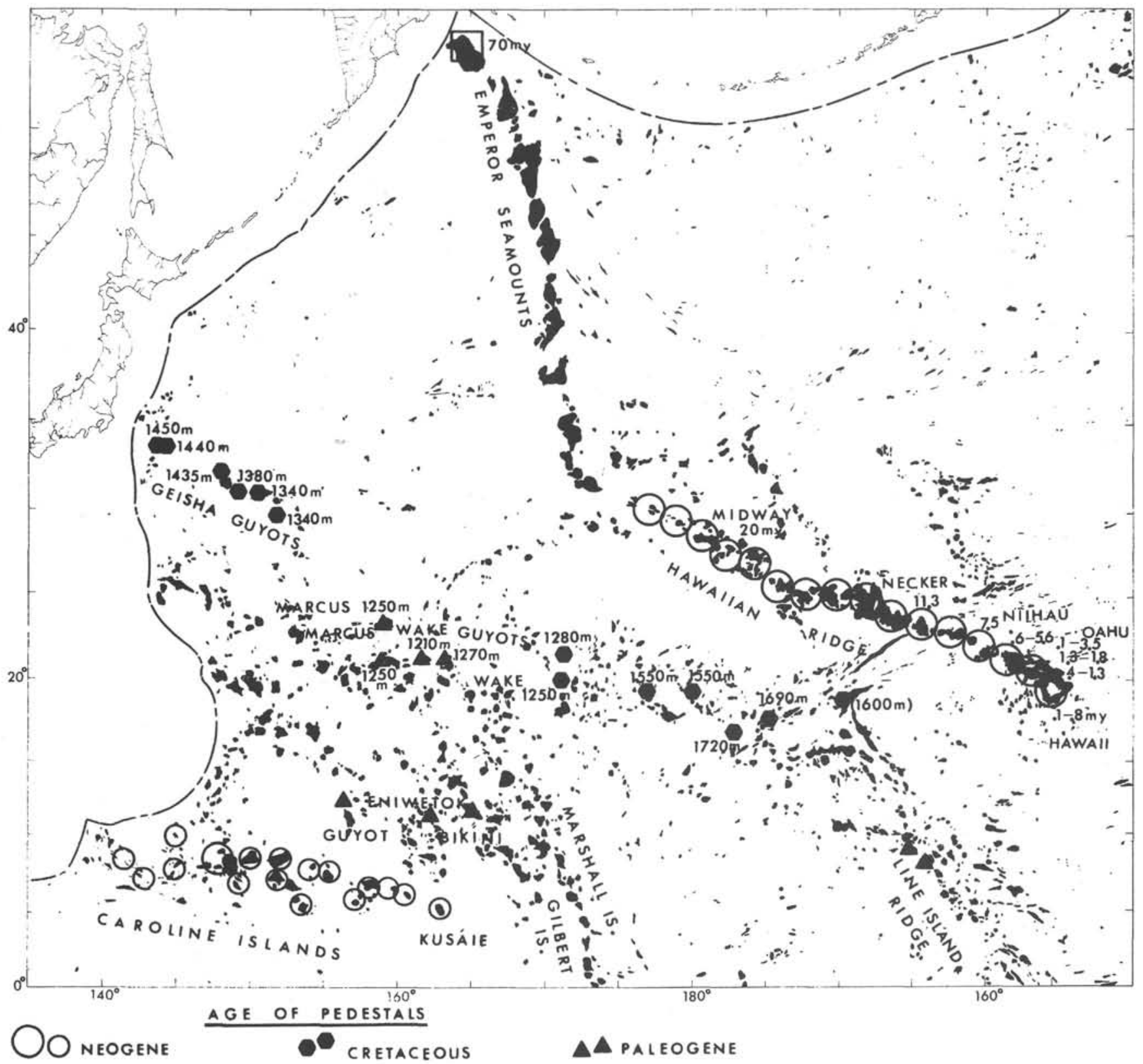

Figure 39. Inferred age of volcanic pedestals in the western Pacific.

carbonate containing ghosts of a Cretaceous pelagic foraminifera deep on the north flank of Scripps Guyot suggests that this guyot is at least Maastrichtian in age and perhaps older. Since sea level was relatively high during the Late Cretaceous and since the Wake guyots are apparently younger than the Mid-Pacific and Geisha guyots, they would likely date from the regression which marked the close of the Mesozoic. However, the summits of the Wake guyots are, on the average, only slightly shallower than the other groups and some lie at depths identical to those of guyots of the western Mid-Pacific Mountains. Thus, if it could be demonstrated that the Wake guyots were created at the close of the Cretaceous, they would establish a lowering of sea level at that time which would have probably left some of the mid-Pacific and Geisha guyots emergent. If this were the case, we would have to explain the absence of shallow-water material of that age from the older guyots.

The summit depths of the guyots of the Mid-Pacific Mountains show an apparently systematic 400-meter shoaling from east to west from Horizon Ridge at $170^{\circ} \mathrm{W}$ longitude to Menard Guyot at $170^{\circ} \mathrm{E}$ longitude. The gradient in crustal age inferred from the correlation and extrapolation of magnetic anomaly patterns detected in the adjacent deep basin suggests an increase in age of about 40 m.y. over this distance. If all guyots of the Mid-Pacific Mountains were formed from reefs and islands by a submergence about 90 m.y. ago, then the east-west crustal age gradient inferred from the magnetic patterns should be compared with the gradient in guyot shoulder depths in 


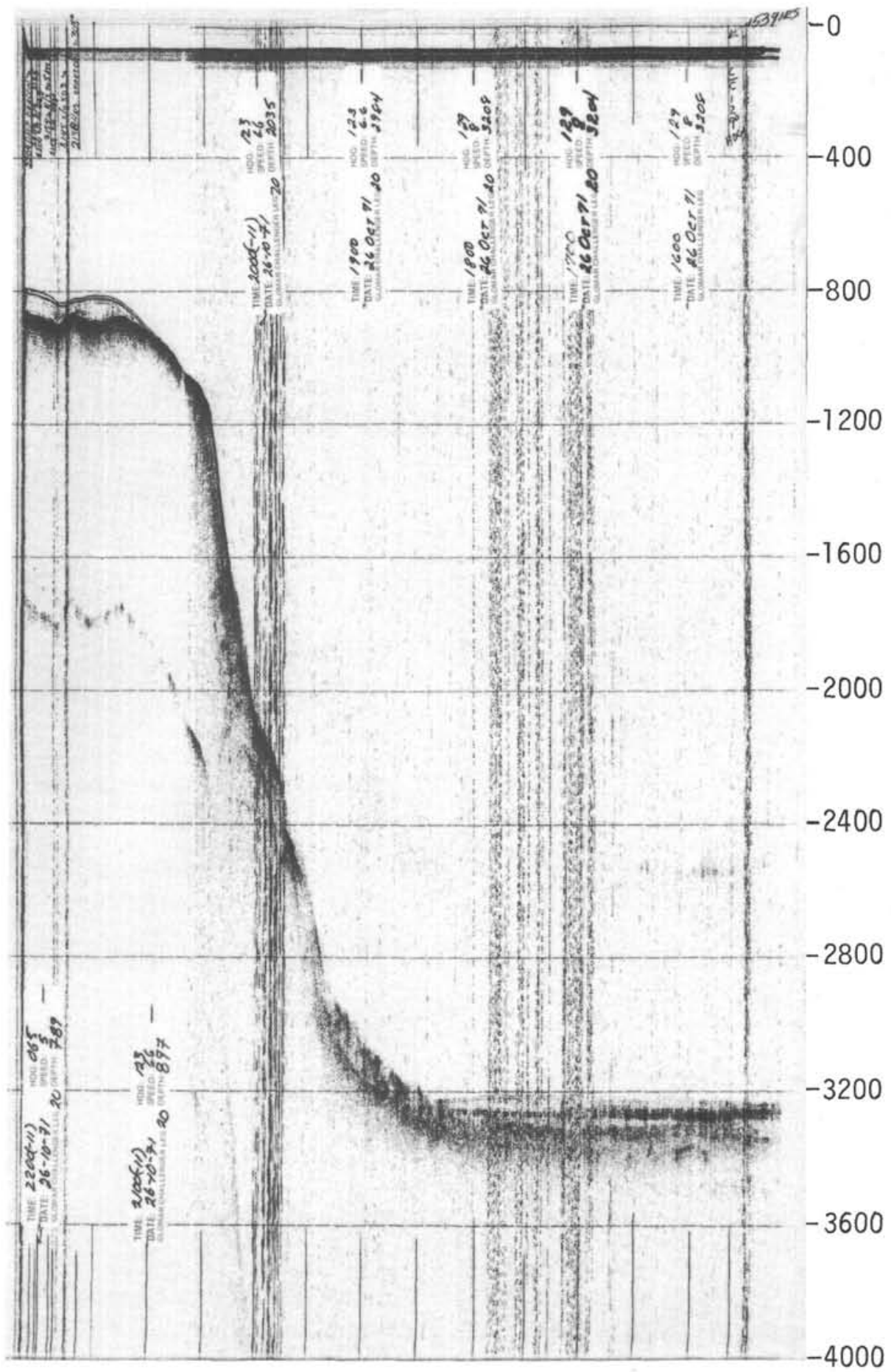

Figure 40. Seismic profile of Ita Mai Tai Guyot. 


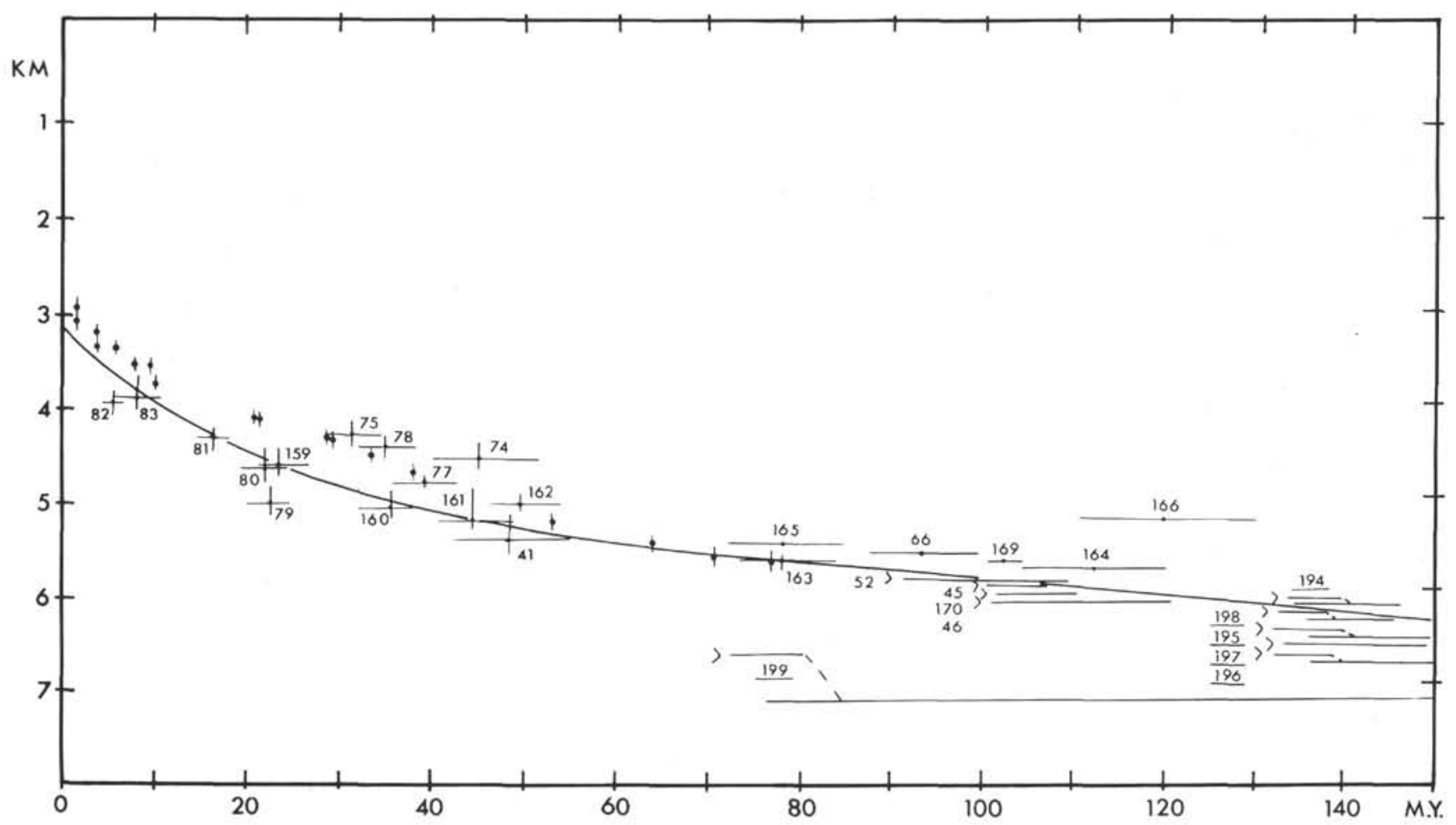

Figure 41. Age vs. depth of Pacific crust.

order to determine if the inferred post-submergence differential subsidence is consistent with the observed relationships of crustal age and ocean depth.

The summit depths of the mid-Pacific guyots are apparently $4.5-5 \mathrm{~km}$ above the adjacent ocean crust, which, with reference to the generalized Pacific subsidence curve (Figure 41), would indicate a minimum age of 30-50 m.y. at the time of subsidence. If the guyots were isostatically and thermally stable features resting on approximately 50 m.y. old crust at the time of submergence, the general subsidence curve would imply a further subsidence of approximately $1 \mathrm{~km}$ over the past 90 m.y.

The summit depths of the Geisha guyots decrease to the southeast, which is also the direction of increasing crustal age inferred from magnetic, acousto-stratigraphic, and drilling results. The gradient is much smaller than in the Mid-Pacific Mountains, implying a greater age of crust at the time of the inferred synchronous drowning. The age of the crust beneath the Geisha guyots of more than 150 million years, implied by magnetic anomalies (Figure 42) and drilling, is apparently 50 m.y. greater than the curst beneath eastern Mid-Pacific Mountains, and thus the smaller summit depth gradient is at least consistent with the greater age of the crust.

The Wake area guyots, although dredged more times than either of the other two groups, failed to yield any reef material. Volcanic rocks associated with lithified Eocene pelagic ooze imply that these guyots submerged in earliest Tertiary, at a much later date than the other two groups of guyots. The summit depths are slightly shallower than the westernmost Mid-Pacific Mountains from which pre-midCretaceous reef material was dredged. It is tempting to assume that reef rocks are there but were not dredged; or that although Cretaceous reefs were never established, the closely similar summit depths imply a mid-Cretaceous age for the initial submergence of the Wake area guyots. However, the Wake area lies just north of the Marshall Islands where drilling to the volcanic pedestal of Eniwetok Island revealed a near identical depth of the pedestal top to that observed for the Wake guyots. The oldest sediments on top of the basalt pedestal were also early Eocene. If the Wake area guyots and the northern Marhsall volcanic platforms are earliest Paleogene in age, and if, according to various estimates, they lie on crust 150-200 m.y. old, then only 0.5 to $1 \mathrm{~km}$ of subsidence in post-Eocene time can be provided by the generalized age-vs.-depth subsidence curve, leaving nearly half of the observed subsidence unaccounted for. The age-vs.-depth curves for oceanic crust is presumably the result of thermal contraction of the cooling lithosphere. Thus, a volcanic event which emplaces large volcanic pedestals on oceanic crust can be expected to perturb the normal subsidence because of the injection of thermal energy and perhaps rock masses of anomalous density. Thus, one expects that the volcanic episodes which created the guyots will have caused a minor uplift and thus have added to the general lithospheric submergence, a much smaller superimposed component of subsidence. The magnitude of this latter effect is at present unknown.

The Mid-Pacific Mountains were originally formed as volcanoes on the northerly-moving Pacific plate. Studies of the remanent magnetism of the volcanic pedestals by Vacquier's method (Francheteau, 1970) indicate that they were created at low southerly latitudes. The motion of the Pacific crust, as inferred from DSDP stratigraphy and by extrapolation of magnetic anomaly patterns, suggests that the guyots of the Mid-Pacific Mountains were within a few 


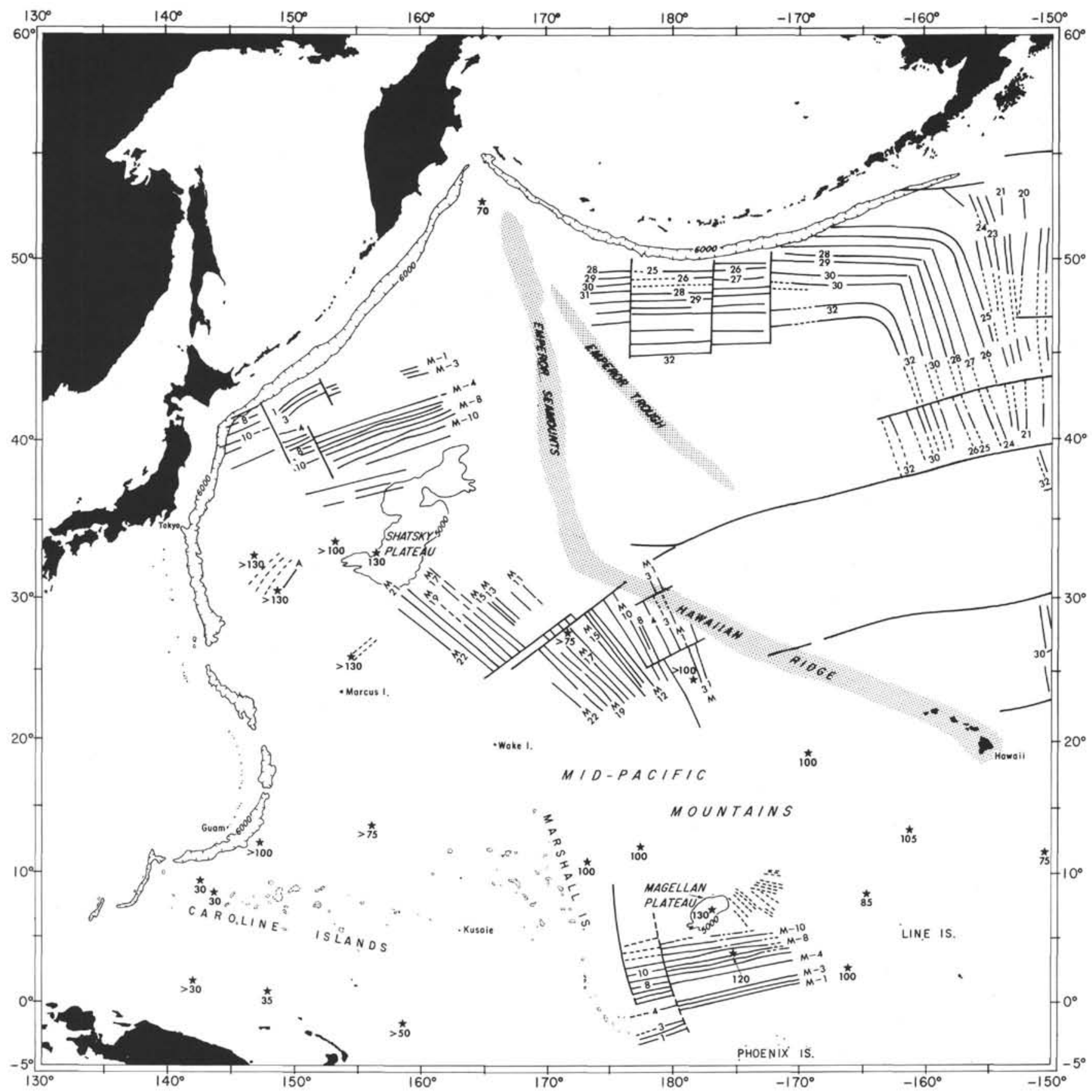

Figure 42. Magnetic lineations in the western Pacific DSDP holes and guyots.

degrees of the equator at the time they were drowned, 90 m.y. ago. The sea level rise must have been abrupt to drown carbonate reefs in the zone of optimum growth. Throughout the world, all oceanic islands which were then more than a few million years old were drowned, creating the majority of the present guyots. Sea level continued to rise during the Late Cretaceous. Most, or all, volcanic islands created during that period of rising sea level were drowned shortly after the termination of volcanic activity. Such seamounts or guyots should stand relatively high in comparison with the older ones. In this regard, one might speculate that the Late Cretaceous pelagic ooze which is now found resting on basalt at a few hundred feet below the present surface of Bermuda may suggest that the Bermuda pedestal was erupted during this transgression. This might explain the anomaly that Bermuda apparently has not subsided more than a few hundred feet since the Late Cretaceous. When at the end of the Mesozoic, the sea began to fall during the great regression, many seamounts created during the intervening transgression progressively became islands and were truncated. The regression ended with the beginning of the Paleogene transgression, and Eocene and later pelagic sediments accumulated on the submerged platforms. Subsequent Tertiary regressions were 
insufficient to expose most of the Cretaceous and early Paleogene guyots but did result in greater winnowing and the consequent creation of hiatuses in the pelagic record preserved on guyots such as Ita Mai Tai and Horizon. The sea level drop at the end of the Cretaceous caused the re-exposure of Early Cretaceous guyots which lay on the oldest crust; however, the guyots of the eastern Mid-Pacific Mountains which had been erupted on fairly young crust subsided sufficiently during transgression to be below the limit reached by the subsequent regressions. Some of the guyots of the Mid-Pacific Mountains, particularly those to the west, which lay on the oldest crust, emerged above the falling sea and were further truncated. At the time of the early Tertiary transgression, those volcanic pedestals which lay near the equator on old, stable, slowly subsiding crust, supported reefs, while the pedestals at higher latitudes and on younger more rapidly subsiding crust drowned. Thus, if the Wake guyots constitute the northern extension of the Gilbert-Marshall line, the absence of present day reefs may be explained by the unfavorable location of the submerging pedestals rather than a difference in age of the pedestals.

We may envisage seamounts originating at various times on the Pacific plate during the Late Jurassic and Early Cretaceous. Sea level was falling during this period which allowed the perpetuation of all oceanic islands with the possible exception of those formed on juvenile crust at higher latitudes. As the extensive Upper Cretaceous transgression began. all oceanic islands were drowned. Islands which lay near the northern limit of coral growth were the first to go. Most of those which had active reefs were also drowned. The ones lying on the oldest crust survived the longest, those on younger crust being drowned more quickly. Oceanic volcanoes created during the rapid eustatic rise may be represented by such anomalous islands as Bermuda. At the end of the transgression, sea level fell again, exposing pedestals on the most ancient crust and allowing erosional processes to bevel the peaks and create the table tops of the guyots. When the sea level again rose, the islands on the oldest crust which lie in the most optimum equatorial environments became atolls while the remainder became guyots. The sea level fluctuations probably caused sympathetic fluctuations in the carbonate compensation depth; thus, the Lower Cretaceous deep-sea carbonates should be more extensive than those that formed during the Upper Cretaceous transgression. The Late Cretaceous-early Tertiary regression may be represented in deep-sea sediments at moderate depths by a carbonate sequence preceded and followed by red clay deposition.

\section{GUYOTS AND DSDP LEG 20, MESOZOIC SEA LEVEL AND OCEAN DEPTHS IN THE NORTHWEST PACIFIC}

Several sites of Leg 20 of the Deep Sea Drilling Project were drilled between the group of guyots and large seamounts which rise from the abyssal depths of the northwest Pacific seaward of the Japan Trench southeast of Tokyo. This group of seamounts was first explored, the existence of guyots confirmed, and a number dredged during the site survey cruise of R/V Thomas Washington in May and June of 1971.
Albian rudistid reef rock and Cenomanian to Senonian chalk were dredged from near the break in slope at the edge of the beveled summits, while weathered basalt was generally obtained a few hundred meters further down the slope. The geological history of the seamounts seems to include a pre-Albian or early Albian volcanic episode which built each pedestal, and a period of reef growth which was terminated in late Albian time by a rapid eustatic rise of sea level that simultaneously drowned the reefs and allowed the accumulation of a subsequent layer of pelagic chalk.

The guyot tops stand approximately 5000 meters above the adjacent deep-sea floor and establish that the DSDP Leg 20 sites lay in $~ 5000$ meters of water in Albian time.

If the depth of the ocean floor is a function of crustal age and if this relationship in the Mesozoic was similar to that established for the Tertiary then we can infer on the basis of the 5000-meter elevation of the guyot above the adjacent crust that the crust beneath Sites 194, 195, and 196 was at least 50 m.y. old in the Albian. It seems unlikely to have been any younger than 50 m.y., but due to the increasingly smaller change of depth with increasing age at ages greater than 50 m.y., an age twice that figure would be quite possible. At Sites 194 and 195, Lower Cretaceous (100-130 m.y.) pelagic sediments were encountered beneath Tertiary and Upper Cretaceous clays. This chalk/chert sequence is interpreted as an equatorial deposit laid down in deep water beneath the equatorial high productivity belt.

The guyot data establish that in the early Cretaceous the ocean depth was about 5000 meters, a bathymetric level which in the late Tertiary Pacific lies well beneath the mid-latitude compensation depth for carbonate. At present, the compensation depth in the Pacific reaches 5000 meters only at the equator and thus the depth of water inferred from the guyots is consistent with our interpretation of the Lower Cretaceous carbonates drilled at Leg 20 sites. The compensation depth is dependent on a variety of factors and may fluctuate upward or downward. A rise of sea level might carry the compensation depth upward with respect to the sea floor and thus might be recorded on the sea floor as an interval between carbonate and clay. Conversely, a lowering of sea level may produce the opposite effect. The termination of carbonate deposition could be a result of an abrupt eustatic rise which could, on the gentle slopes of the deep-sea floor, cause a radical shift in the distribution of ooze and clay. The seamounts and guyots provide one of the few indices of the absolute ocean depth in the past and together with deep-sea stratigraphy offer us a good possibility of determining the history of eustatic sea level and of determining fluctuation in the carbonate compensation depth.

\section{ACKNOWLEDGMENTS}

The authors are indebted to Dr. E. L. Winterer who arranged that the R/V Thomas Washington be made available to the senior author for Leg 5 of the ARIES Expedition. We thank Captain Ferris, and the technicians and crew of $\mathrm{R} / \mathrm{V}$ Thomas Washington for their help in making the cruise a decided success.

The study of carbonates and phosphates was begun by Catalano while at Princeton University and concluded at the 
Geological Institute of Palermo University. We thank Dr. A. Fischer for his assistance in initiating the study and for subsequent help. S. Honjo made available a stereoscan electron microscope and provided other valuable assistance. M. Hermelin collaborated with Catalano in the X-ray analyses, and R. Bathurst made valuable suggestions on carbonate petrography. The writers thank E. L. Winterer for permission to report fossil and radiometric age data on Necker Ridge.

The study of volcanic rocks was undertaken at Scripps Institution of Oceanography by Natland, who is indebted to Prof. J. Hawkins for encouragement. Mr. and Mrs. R. DeHaven prepared the thin sections. T. Vallier D. Clague, and E. L. Winterer provided helpful comments and discussion.

This research was supported by the Office of Naval Research under contract N-00014-67-A-01-0036 with Columbia University, and with the University of California.

\section{REFERENCES}

Ames, L. L., Jr., 1959. The genesis of carbonate apatites: Econ. Geol. v. 54, p. 819.

Arrhenius, G., 1963. Pelagic Sediment. In The Sea v. 3. The earth beneath the sea: New York (Interscience), p. 655.

Bandy, M. C., 1937. Geology and petrology of Easter Island: Geol. Soc. Am. Bull., v. 48, p. 1589-1610.

Bass, M. N., Moberly, R. M., Rhodes, J. M., and Shin, C., 1973. Volcanic Rocks, Leg 17. In Winterer, E. L., Ewing, J. I. et al., Initial Reports of the Deep Sea Drilling Project, Volume XVII: Washington (U.S. Government Printing Office).

Bathurst, R. G. C., 1964a. The replacement of aragonite by calcite in molluscan shell walls. In Imbrie, J. and Newell, N. (Eds.) Approaches to Paleoecology; New York (John Wiley and Sons), p. 357-376.

1966. Boring algae, micritic envelopes and lithification of molluscan biosparites: Geol. J., v. 5, p. 15-32.

, 1971. Carbonate Sediments and their diagenesis: Devel. Sediment. no. 12, Amsterdam (Elsevier), p. 620.

Dietz, R. S., Emery, K. O., and Shepard, F. P., 1942. Phosphorites deposits on the sea floor off southern California: Geol. Soc. Am. Bull., v. 53, p. 815.

Douglas, R. G., Moullade, M., and Nairn, A. E. W., 1973. Causes and consequences of drift in the South Atlantic. In Tarling, D. H., and Runcorn, S. K. (Eds), Implications of Continental Drift to the Earth Sciences, Vol. 1: Academic Press, New York, p. 517-537.

Ewing, J., Ewing, M., Aitken, T., and Ludwig, W. J., 1968. North Pacific sediment layers measured by seismic profiling: In Geophys. Mono. no. 12, The Crust and Upper Mantle of the Pacific Area, Am. Geophys. Union, 147-173.

Fischer, A. G. and Garrison, R. E., 1971. Carbonate lithification on the sea floor: J. Geol., v. 75, p. 488.

Francheteau, J., Harrison, C. G. A., Sclater, J. G., and Richards, M. L., 1970. Magnetization of Pacific seamounts: A preliminary polar curve for the northeastern Pacific: J. Geophys. Res. v. 75 (11), p. 2035-2061.

Friedman, G. M., 1964. Early diagenesis and lithification in carbonate sediments: J. Sediment. Petrol., v. 34, p. $777-813$

Hamilton, E. L., 1956. Sunken islands of the Mid-Pacific Mountains: Geol. Soc. Am. Mem. 64.
Hamilton, E. L. and Rex, R. W., 1959. Lower Eocene phosphatized globigerina ooze from Sylvanis Guyot: U. S. Geol. Survey Prof. Paper 260-W, p. 784-797.

Hess, H. H., 1946. Drowned ancient islands of the Pacific basin: Am. J. Sci., v. 244, p. 772.

Heezen, B., Matthews, J. L., Catalano, R., Tharp, M., and Rawson, M., 1972. The geology of western Pacific guyots: Geol. Soc. Am. Abstr. v. 4, 3 Feb. 5 (1972), 1969.

Jackson, E. D., Silver, E. I., and Dalrymple, G. B., 1972. Hawaiian-Emperor Chain and its relation to Cenozoic circum-Pacific tectonics: Geol. Soc. Am. Bull., v. 83, p. 601 .

Kazakov, A. V., 1937. The phosphorite facies and the genesis of phosphorites: Sci. Inst. Fertilizers and Insects-Fung., Trans., v. 142, p. 95.

Kuno, H., Fisher, R. L., and Nasu, N., 1955. Rock fragments and pebbles dredged near Jimmu Seamount, northern Pacific: Deep-Sea Res., v. 3, p. 126-133.

Land, L. S., 1970. Phreatic versus vadose meteric diagenesis of limestones: evidence from a fossil water table: Sedimentology, v. 14, p. 175.

Larson, R. L. and Chase, C. G., 1972. Late Mesozoic evolution of the western Pacific Ocean: Geol. Soc. Am. Bull., v. 83(12) p. 3627-3644.

Larson, R. L. and Pitman, W. D., 1972. Worldwide correlation of Mesozoic magnetic anomalies, and its implications: Geol. Soc. Am. Bull., v. 83, p. 3645-3662.

Lonsdale, P. F., Normark, W. R., and Newman, W. A., 1972. Sedimentation and erosion on Horizon Guyot: Geol. Soc. Am. Bull., v. 83, p. 189-316.

Macdonald, G. A., 1942. Potash-oligoclase in Hawaiian lavas: Am. Mineral., v. 27, p. 793.

Macdonald, G. A., 1968a. A contribution to the petrology of Tutuila, American Samoa: Geol. Rundschau, v. 57, no. 3 (Rittman) p. 821-837.

Macdonald, G. A., 1968b. Composition and origin of Hawaiian lavas. In Coats, R. R., Hay, R. L., and Anderson, C. M. (Eds), Studies in Volcanology: Geol. Soc. Am. Mem. 116 (Williams v.), p. 477-522.

Macdonald, G. A. and Katsura, T., 1964. Chemical composition of Hawaiian lavas: J. Petrol., v. 5, p. 82.

Marlowe, J. I., 1971. Dolomite, Phosphorite and carbonate diagenesis on Caribbean seamounts: J. Sediment. Petrol., v. 41 (3), p. 809.

McBirney, A. R., 1967. Genetic relations of volcanic rocks of the Pacific Ocean: Geol. Rundschau, v. 57, p. 21-33.

McBirney, A. R. and Aoki, K., 1968. Petrology of the island of Tahiti. In Coats, R. R., Hay, R. L., and Anderson, C. M. (Eds.) Studies in Volcanology: Geol. Soc. Am. Mem. 116 (Williams v.), p. 523-556.

McBirney, A. R. and Gass, I. G., 1967. Relations of oceanic volcanic rocks to mid-oceanic rises and heat flow: Earth Planet. Sci. Lett., v. 2, p. 265-276.

McBirney, A. R. and Williams, H., 1969. Geology and petrology of the Galapagos Islands: Geol. Soc. Am. Mem. 118, 197 pp.

McConnell, D., 1938. A structural investigation of the isomorphism of the apatite group: Am. Mineralogist, v. 23 , p. 1 .

McDougall, I., 1964. Potassium argon ages from lavas of the Hawaiian Islands: Geol. Soc. Amer. Bull., v. 75, p. $107-128$.

Menard, H. W., 1964. Marine Geology of the Pacific: New York (McGraw-Hill), 271 pp.

Millimann, J. D., 1966. Submarine lithification of carbonate sediments: Science, v. 153, p. 994. 
Muir, I. D. and Tilley, C. E., 1961. Mugearites and their place in alkali igneous rock series: J. Geol. v. 69, p. 186-203.

Ozima, M., Kudo, K., Saito, K., and Jarrard, R., in preparation. Evaluation of $\mathrm{K}-\mathrm{Ar}$ ages of submarine basalts.

Schroeder, J. H., 1972. Calcified filaments of an endolithic alga, in recent Bermuda Reefs: N. Jb. Geol. Paleont. v. 1, p. 16.

Sclater, J. G., Anderson, R. M., and Bell, M. L., 1971. Elevation of ridges and evolution of the central eastern Pacific: J. Geophys. Res., v. 76 (32), p. 7888-7915.

Smith, W. C. and Shubb, L. J., 1927. The petrography of the Austral and Tubuai Islands (southern Pacific); Geol. Soc. London, Quart. J., v. 83, p. 317-341.

Wanless, H. R., and Shepard, F. P., 1936. Sea level and climatic changes related to late Paleozoic cycles: Geol. Soc. Amer. Bull., v. 47, p. 1177-1206.

Williams, Howel, 1933. Geology of Tahiti, Moorea and Maiao, B. P.: Bishop Mus. Bull. 105.

Williams, Howel, Turner, F. J., and Gilbert, C. M., 1954. Petrography: an introduction to the study of rocks in thin section: San Francisco, (W. H. Freeman) 405 pp.

Winterer, E. L., Ewing, J. I., et al., 1973. Initial Reports of the Deep Sea Drilling Project, Volume XVII: Washington (U. S. Government Printing Office). 



\section{PLATE 1}

Figure $1 \quad$ White pelagic phosphatized chalk with manganese crusts. Middle Eocene. Burrows are filled with more recent foraminiferal mud. Dredge 5.

Figure 2 Porous shoal water coquina limestones. Lower Cretaceous. The fossils are preserved as molds and casts as well as the original structure of the test. Dredge 31 .

Figure 3 Rudistid limestones. Caprinid entirely phosphatized. Cretaceous. Dredge 10.

Figure 4 White to tan phosphatized limestone breccia with volcanic clasts. Eocene. Indurated phosphatized foraminiferal chalk, burrowed and filled up, coated at this erosional surface by a manganese layer, overlain by a phosphatized microbreccia that, in the upper part, appears strongly stained by phosphate and iron-manganese oxides. Dredge 22.

Figure $5 \quad$ Bioclastic calcarenites. Cretaceous. The fossils are molluscs, small corals, echinoid spines, often as molds or clasts. The small tubes found in the ostrea shell represent the casts of borings, the original calcite of the shell being dissolved. Dredge 31 .

Figure 6

Indurated and iron-manganese coated foraminiferal phosphorites with embedded volcanic clasts, overlain by indurated volcanic ash. The volcanic material shows cracks filled with foraminiferal ooze. Eocene. At the upper right the black crust of iron-manganese. Dredge 19.

Figure $7 \quad$ White indurated foraminiferal chalk with imbedded clast of various material. Eocene. The casts appear Manganese coated. The matrix is phosphatized in patches (dark gray spots). Dredge 25.

Figure 8 Rudistid limestones. Phosphatized rudistid. Cretaceous. Dredge 33.

Figure 9 Indurated pelagic foraminiferal phosphorites. Upper Cretaceous. The work appears bioturbated. Animal borings (womrs?) filled up with lamellar phosphatized material. Dredge 32. 


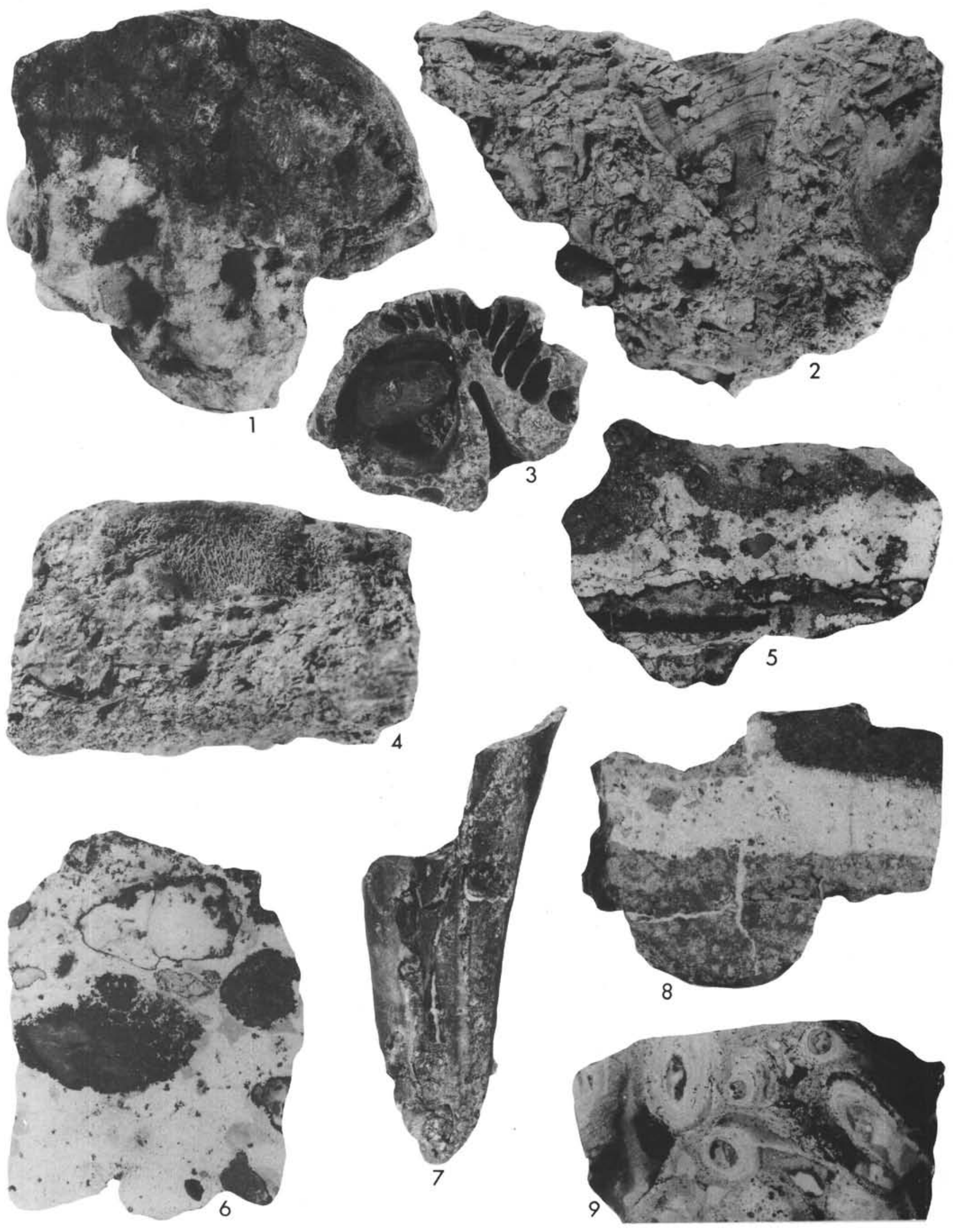




\section{PLATE 2}

Figure 1 Pelagic phosphorites bioturbated and bored by animals. Cretaceous. Globotruncana sp. and other planktonics appear pulled aside by the action of animals, which seem to have bored and filled the bores with lamellar material, later phosphatized. (See hand specimen in Plate I, Figure 9). Dredge 22.

Figure 2 Pelagic foraminiferal phosphorites. Middle to Upper Cretaceous. In the fine coccolith-rich matrix, wholly phosphatized, are imbedded Globotruncanae, otoliths, fish teeth, calcitic echinoid plates, and other organic remains which show evidence of distinctly birefringent phosphate. Crossed micols. Dredge 30.

Figure 3 Pelagic phosphatized chalks. Cenomanian-Turonian. Planktonic foraminifera show a geopetal fine-grained crystalline material filling the chamber cavities. These are often partially empty within the chamber. Dredge 10.

Figure 4 Pelagic calcilutites. Eocene. Micritic matrix is generally composed of coccoliths, planktonic foraminifera and their fragments. The foraminifera are partially filled with mud. The foraminiferal tests are often dissolved.

Figure 5 Pelagic lutitic phosphorites. Among the heterogeneous fauna, the oldest foraminifera point to a middle Eocene age. The fine-grained matrix is entirely phosphatized partly filled foraminifera. Dredge 22.

Figure 6 Pelagic chalks phosphatized in spots. Middle Eocene. Among the heterogeneous fauna it was possible to distinguish Tr. topilensis, Gl. psis index, etc., pointing to a middle Eocene age. The foraminiferal tests show different stages of dissolution. At the lower left corner, a boring partially filled with recent and well-preserved planktonic foraminifera. Dredge 3.

Figure $7 \quad$ Pelagic phosphorites. Cretaceous. This slide shows the typical patterns of phosphatization. The original mud is stained in patches by iron-manganese. Dredge 37.

Figure $8 \quad$ Pelagic foraminiferal phosphatized chalks. Eocene. The phosphatization occurs repeatedly displaying layers of optically resolved and birefringent phosphate interbedded with a phosphatized foraminiferal chalk with iron-manganese intimately intergrowing. In the picture, the formainifera are well preserved (bottom) or wholly dissolved (top) but are almost absent in the layers where iron-manganese oxides are abundant. Crossed nicols. Dredge 22. 

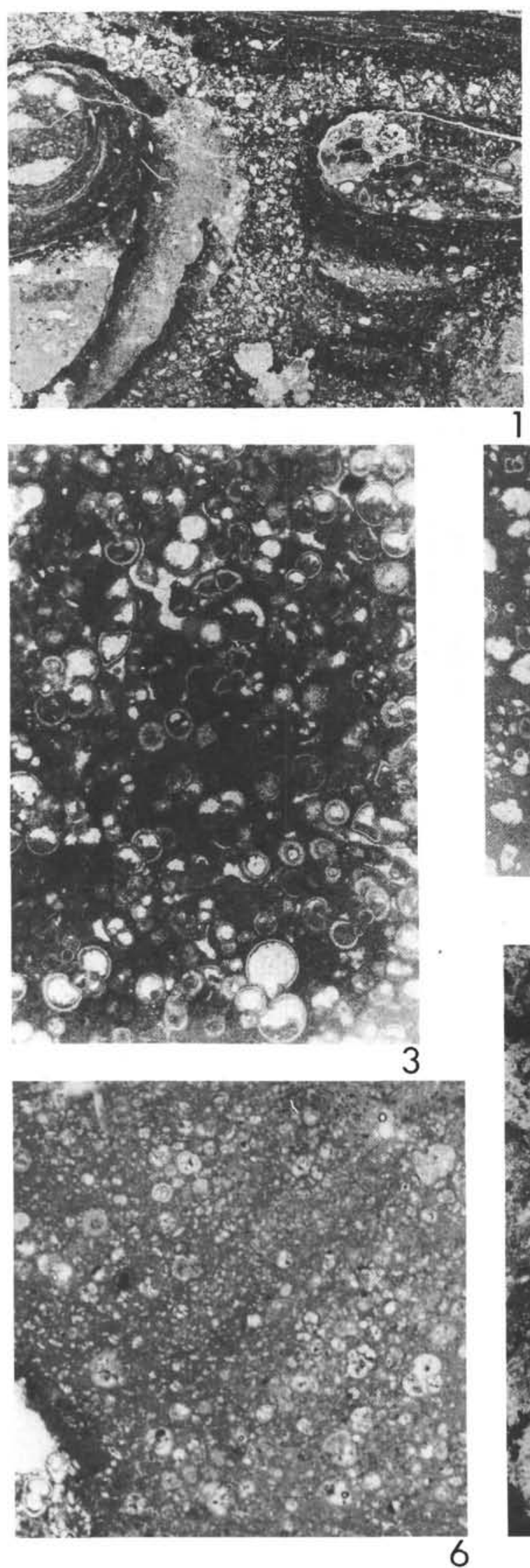
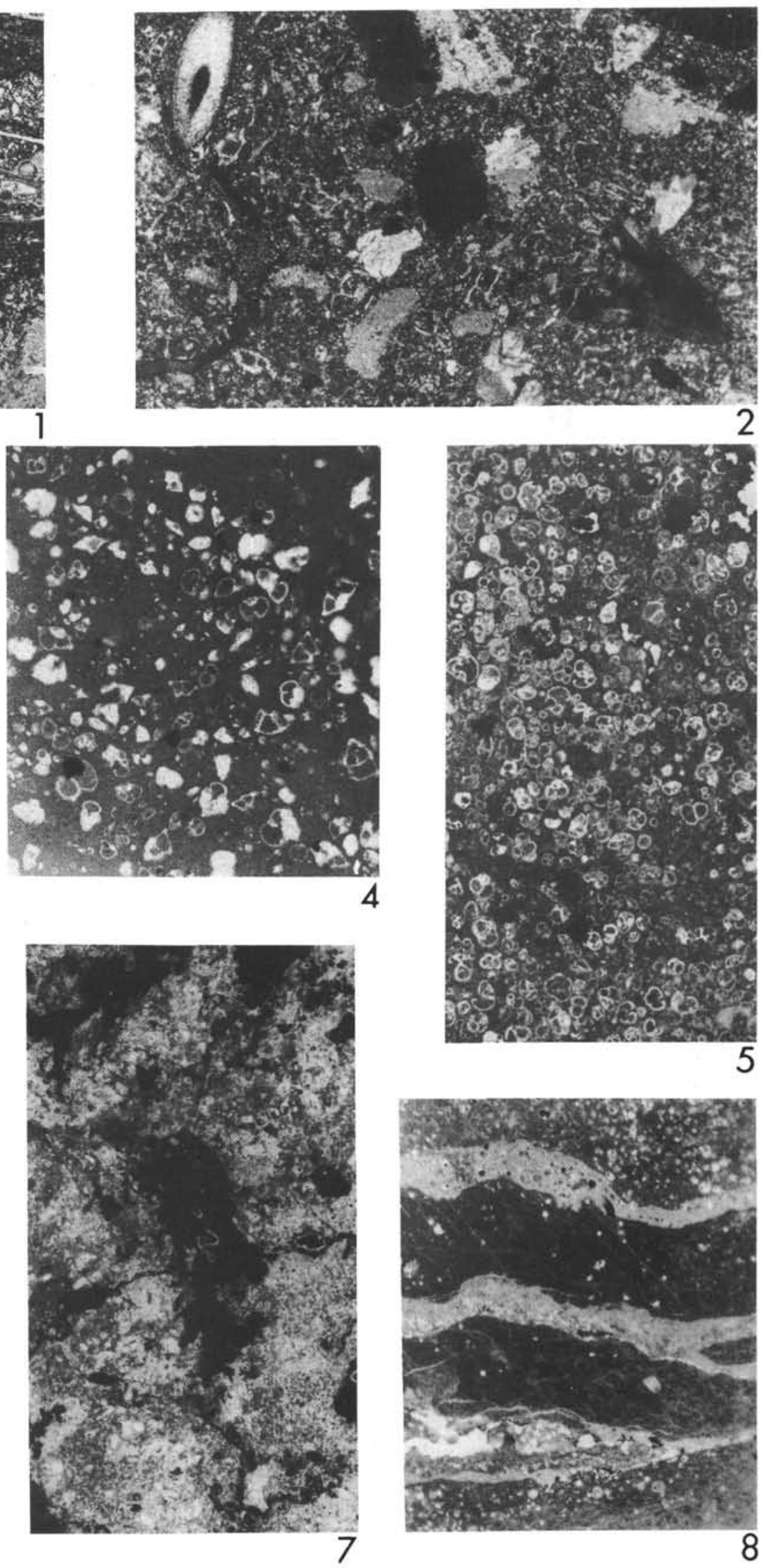
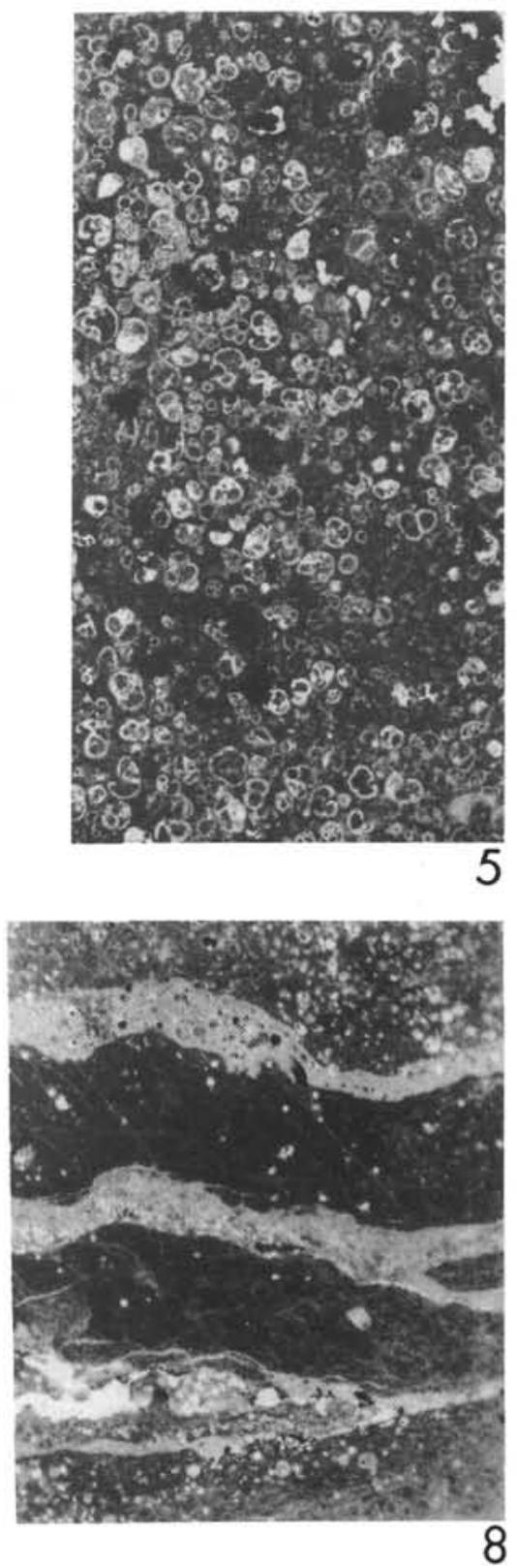


\section{PLATE 3}

Figure 1

Figure 2

Figure 4

Figure 5

Figure 6.
Very highly porous bioclastic calcarenites. Lower Cretaceous. Skeletal fragments are mollusc tests, coralline algae, echinoid plates, etc. Micrite envelopes are diffuse and well preserved and appear coated by an even fringe of calcite crystals cement. The porosity is intergranular and intramicrite-envelope. The dissolution of the original unstable minerals is not balanced by calcite cement precipitation. Within some dissolved bioclasts a ferruginous Globigerinamud fills the cavities. (See left of picture.) Dredge 30.

Fairly porous bioclastic calcarenites. Cretaceous. Components are algal fragments, mollusc fragments, echinoid plate and pspines, arenaceous foraminifera (as Orbitolina sp.), and other organic remains. The intergranular pores are generally filled by micrite. The grain margins show evidence of calcitic cement. Dredge 31.

Highly porous bioclastic calcarenites. Lower Cretaceous. Skeletal grains are molluscs, coralline algae, echinoid plates, arenaceous foraminifera, and other shallow-water organisms. Dredge 39.

Well cemented and fairly porous bioclastic calcarenite-Cretaceous. The components are mollusc fragments, algae, stromatoporoids, and echinoid plates. The skeletal grains are subangular and preserve the original test texture; they show an even cement fringe. Dredge 15.

Porous bioclastic calcarenites. Cretaceous. Wellrounded and sorted grains. An even cement fringe is seen around the clast. The porosity is mostly intergranular. Micrite envelopes diffused and well preserved. Dredge 30.

Enlarged view of Figure 3. Fringe cement uniformly on the grain surface covered by early micrite envelope. Intergranular and intra-micrite envelope porosity. Micrite envelopes enclose a partly dissolved shell fragment. 

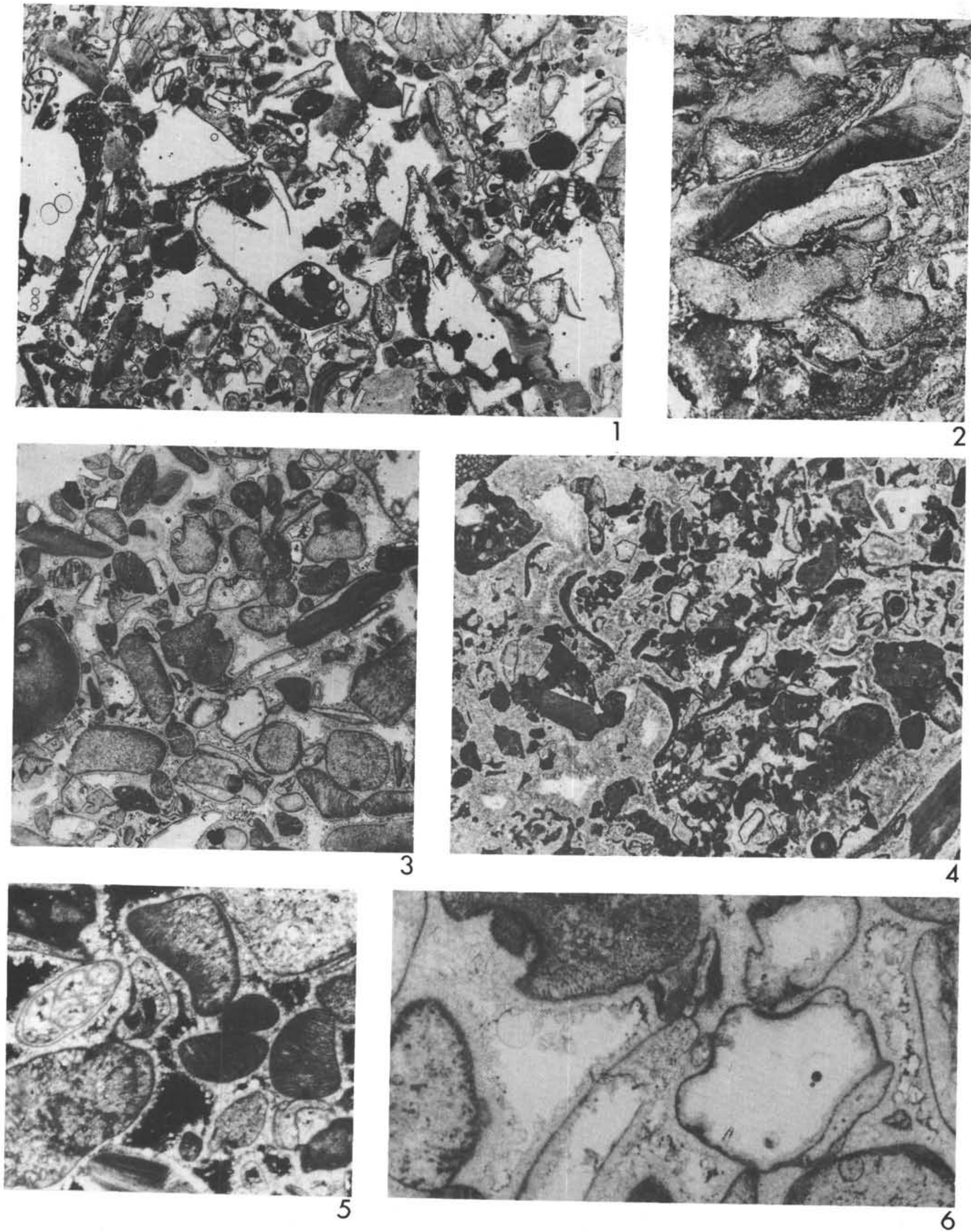


\section{PLATE 4}

Figure 1 Pelagic foraminiferal lutitic phosphorites. The assemblage is heterogeneous but the oldest fauna points to a middle Eocene age. The tests of foraminifera are phosphatized and show the pattern of preservation in negative detail. Some of them are wholly dissolved. Black spots are iron-manganese oxides. Dredge 22.

Figure 2 Pelagic foraminiferal chalks. In the picture, the interior of the foraminiferal chamber is filled with small rhombohedral calcite crystals or with radial calcite cement. In the fine-grained matrix, large crystals of sparry (neomorphic?) calcite (upper right corner). Dredge 10. Stereoscan electron micrograph of fracture surface gold and carbon coated.

Figure 3 Pelagic nannofossil chalky phosphorites. Coccolith and their fragments are replaced by (or encrusted by?) a delicate phosphate pellicle. According to this interpretation, the picture shows the molds of the original organisms. Dredge 31. Stereoscan electron micrograph of fracture surface gold and carbon coated.

Figure 4 Pelagic foraminiferal chalky phosphorites. Eocene. Part of the foraminiferal test walls entirely phosphatized. The outer wall is partially destroyed showing only the inner wall which is now represented by a thin film of amorphous phosphate (white grains in the picture). Euhedral hexagonal francolite crystals filled the foraminiferal chamber, perhaps replacing the original calcite sediment. The pilars are the phosphate filling of the original pore in the test, prior to the calcite dissolution. Dredge 20. Stereoscan electron micrograph of a fracture surface gold and carbon coated.

Figure 5 Pelagic chalky phosphorites. Eocene. Foraminiferal test walls. The inner wall is in the upper part of the picture. The pillars are molds of the original pores. The two walls appear as a flat body of crystalline phosphate, encrusted by amorphous phosphate. At the top the hexagonal francolite crystals are part of the chamber filling, and at the bottom the francolite crystals constitute the loosely packed matrix of the rock. In this case the calcite dissolution left empty spaces that are later filled with euhedral crystalline phosphate. Dredge 22. Stereoscan electron micrograph of a fracture surface gold and carbon coated.

Figure 6 Pelagic chalky phosphorites. Eocene. Section of a planktonic foraminiferal test. The inner wall appears made by euhedral francolite crystals. The pillars come down from the phosphatized outer wall. At the bottom, euhedral hexagonal francolite loosely aggregate are part of the chamber filling. Dredge 22. Steroscan electron micrograph of a fracture surface gold and carbon coated. 

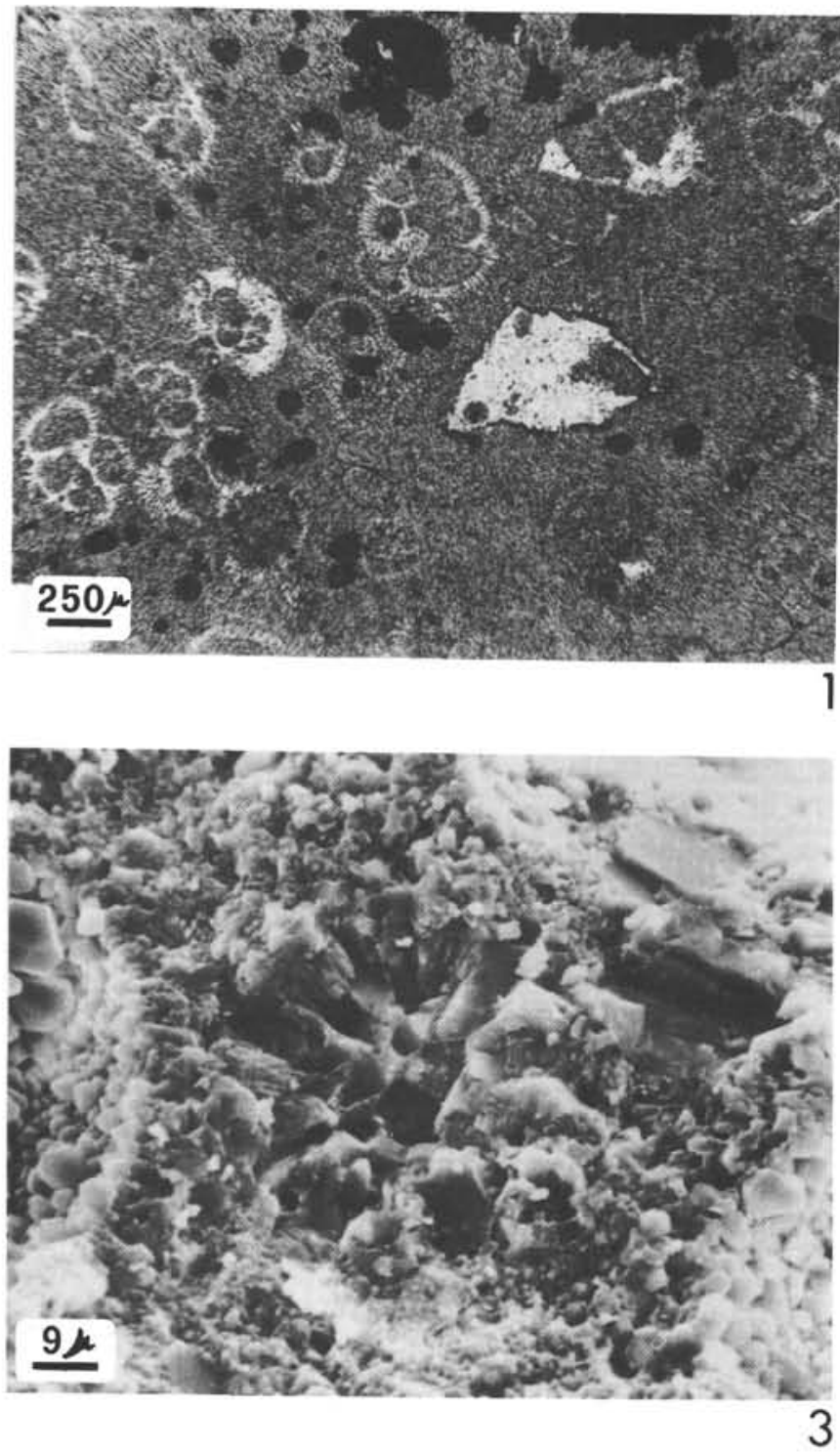

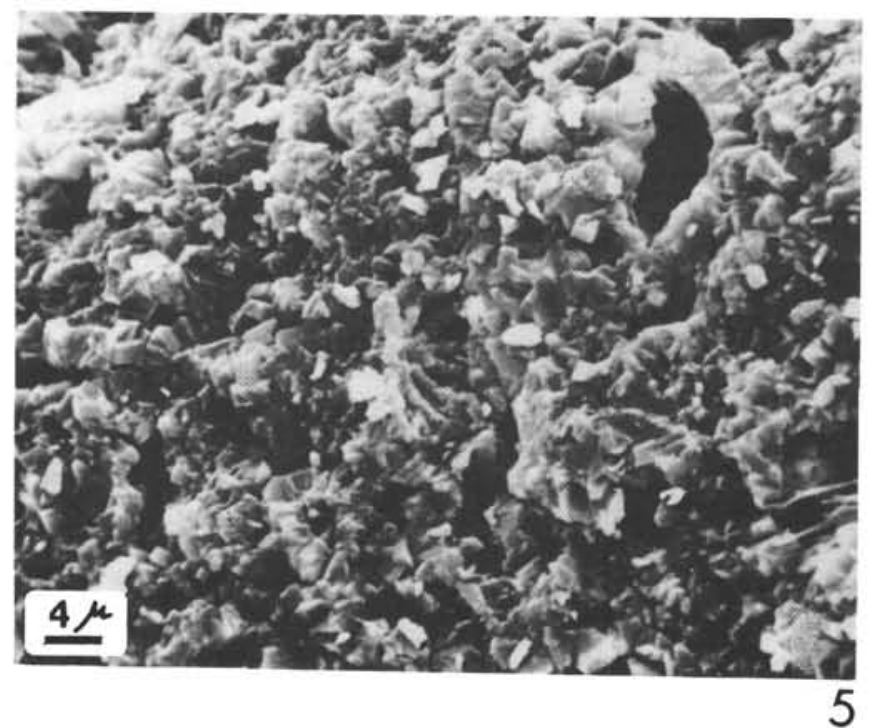
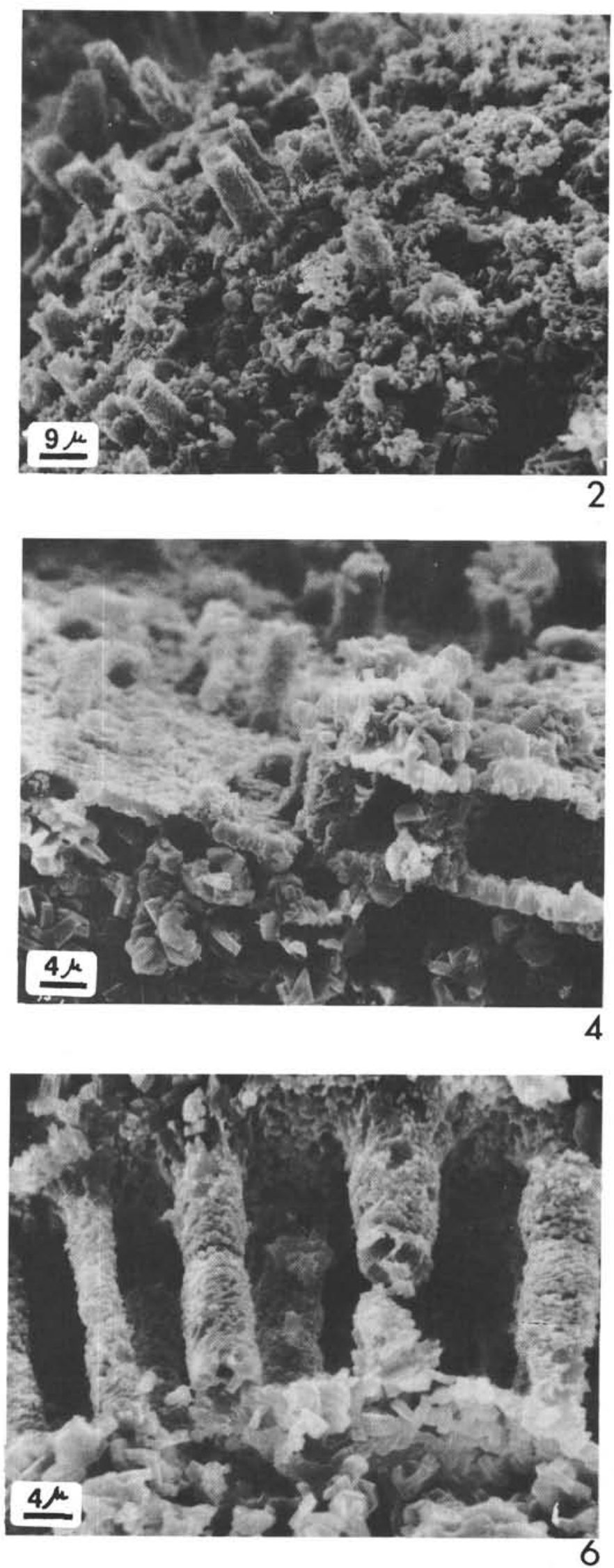


\section{PLATE 5}

Figure 1 Phosphatized biocalcarenites. Cretaceous. Components are corals, molluscs (Caprinids), echinoids and related fragments. The phosphate replaced the original calcareous texture (grains and cements). Dredge 29.

Figure 2 Bioclastic Phosphorites. Cretaceous. Bioclasts, more or less cemented, are completely altered by phosphatization. Globular features are ironmanganese concretions. Steroscan electron micrograph of fracture surface gold and carbon coated.

Figure 3 Phosphatized biocalcarenites. Cretaceous. Enlarged view of the microstructure of shell wall in a gragment of Figure 1. The hexagonal or tabular francolite crystals appear in small aggregates, loosely packed. White anhedral crystals are calcite. Dredge 29. Stereoscan electron micrograph of fracture surface gold and carbon coated.

Figure 4 Phosphatized biocalcarenites. Cretaceous. Amorphous phosphate (at right side) and an iron-manganese fringe intermingled with francolite in a bioclast. Dredge 31. Stereoscan electron micrograph of fracture surface gold and carbon coated.

Figure 5 Bioclastic calcarenites. Cretaceous. Enlarged view of an echinoid clast coated by micritic envelope (white grains) and by intergranular calcite cement fringes (black). Dredge 30. Stereoscan electron micrograph of fracture surface gold and carbon coated.

Figure 6 Bioclastic calcarenite. Enlarged view of Figure 4. The white anhedral grains are calcite crystals forming the micrite envelope. Dredge 30. Stereoscan electron micrograph of fracture surface gold and carbon coated. 

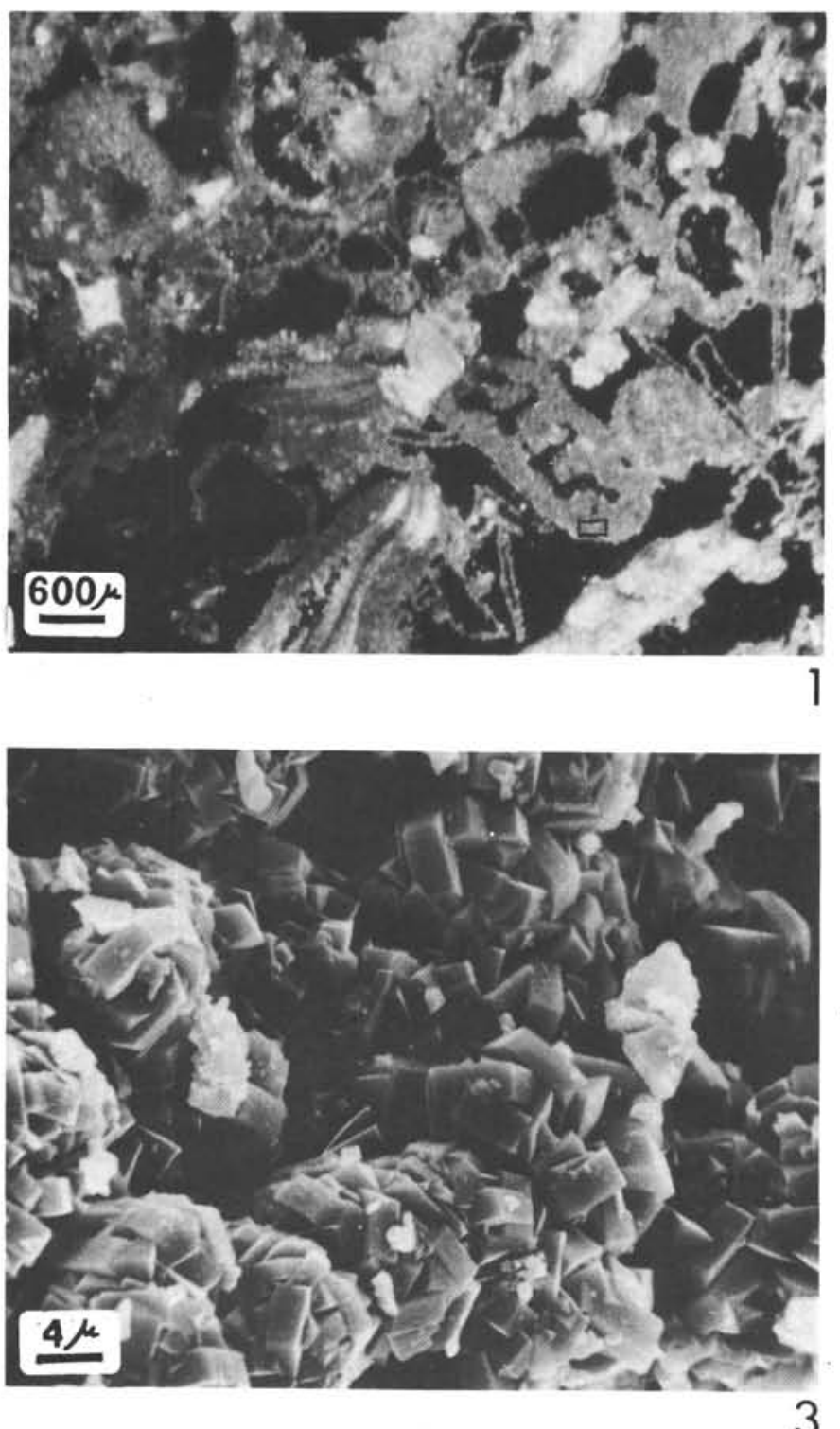
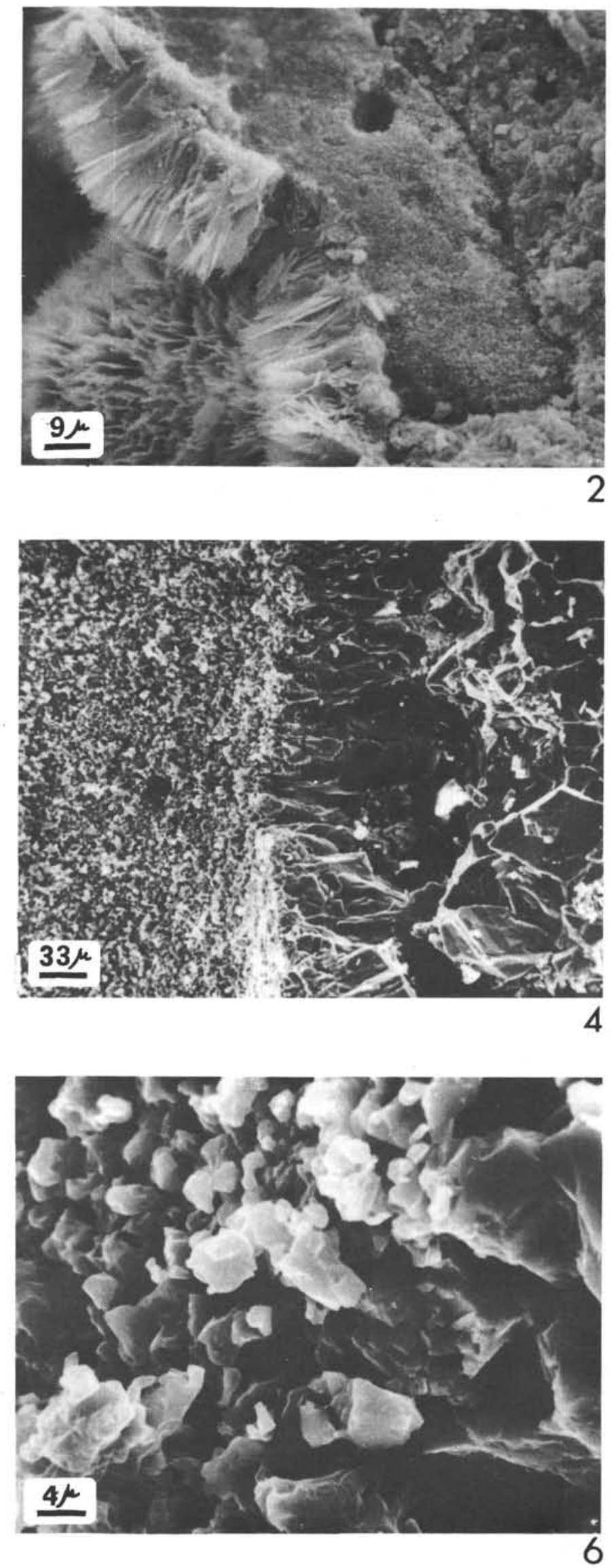
PLATE 6

Figure 1 Bioclastic calcarenites. Cretaceous. The calcite cement has replaced the partially dissolved core of the calcitic clast (algae). The micrite envelope is surrounded by an even fringe of calcitic cement. Dredge 30.

Figure 2 Bioclastic calcarenites. Cretaceous. Enlarged view of a dissolved pelocypod test fragment showing a delicate micrite envelope. Two generations of cement are visible. The primary, thin rind of rhombohedral calcite crystals, growing from the micrite envelope, are approximately 40 microns in size. The secondary, rhombic coarse-grained calcite crystals fill intergranular cavities. Triple junctions are rare. Dredge 10.

Figure 3 Bioclastic calcarenites. Cretaceous. Enlarged view of envelope of algal (?) remains. The tabular masses of micrite possibly represent filled algal bores or calcitized endolithic algae. Dredge 10.

Figure 4 Bioclastic calcarenites. Cretaceous. Enlarged view of an intergranular pore. Two generations of cement are visible. Dredge 30. 

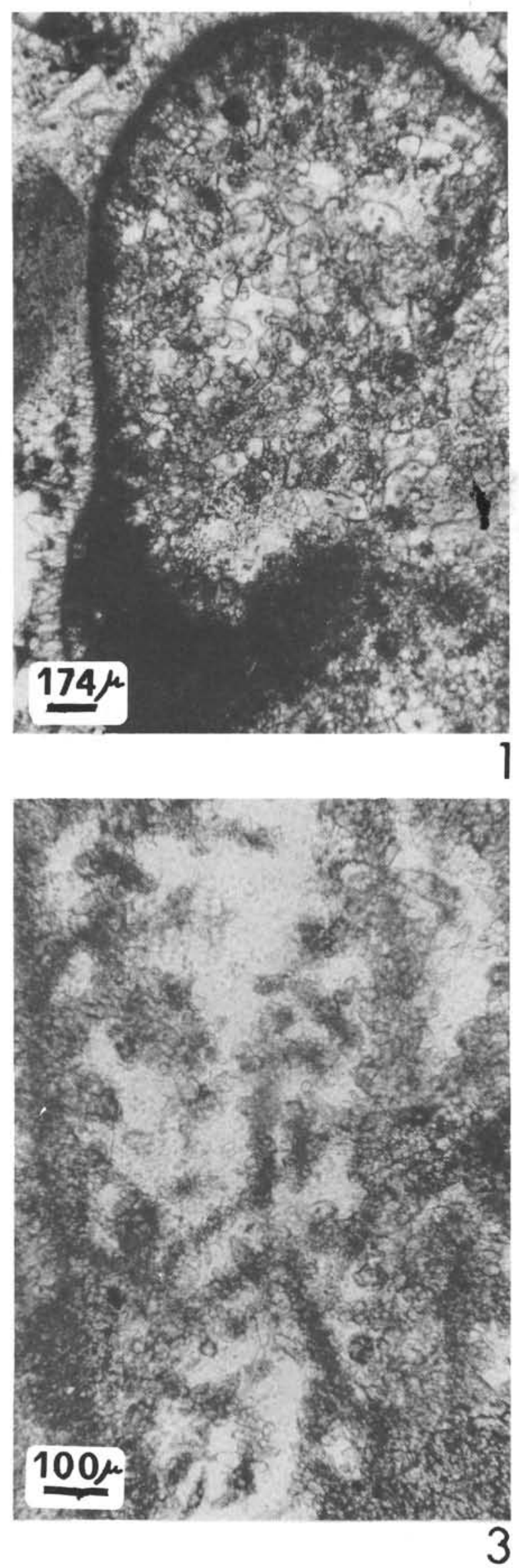
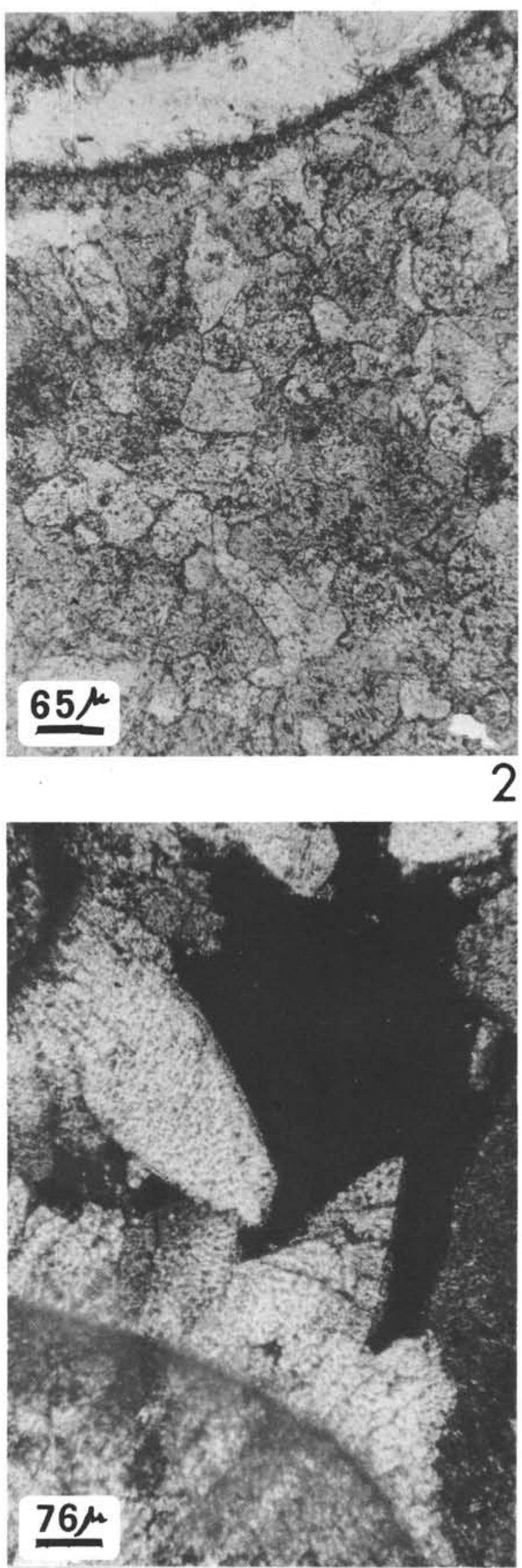


\section{PLATE 7}

Figure $1 \quad$ Bioclastic calcarenites. Oblique section through a stromatoporoid showing concentric laminae and radial pillars. Cretaceous. The skeletal structure (black) is lined by a gray fibrous cement, which grows from the wall of the galleries; the cavities are filled with a sparry calcite cement (white). Dredge 15.

Figure 2 Enlarged view of Figure 1. It is possible to distinguish two different types of cement. A radial fibrous (acicular) one (gray), growing from the walls; a coarse-grained sparry calcite cement (white) precipitated in the cavities. Dredge 15.

Figure 3 Enlarged view of Figure 2. the even, radial, fibrous rind of calcite cement that could have been originally magnesium calcite or aragonite, shows the patterns of a marine phreatic diagenesis while the large crystals filling the cavities point to a phreatic meteoric diagenesis. Thus, the two cement generations indicate that the rocks first formed in a marine phreatic zone (no later) passed into a meteoric phreatic zone.

Figure 4 Bioclastic calcarenites. Cretaceous. Skeletal grains cemented by a thin rind of calcite crystals. Note on the echinoid plate the even cement rim which appears to have filled the intergranular space and buried the first generation of cement (around the clast). 

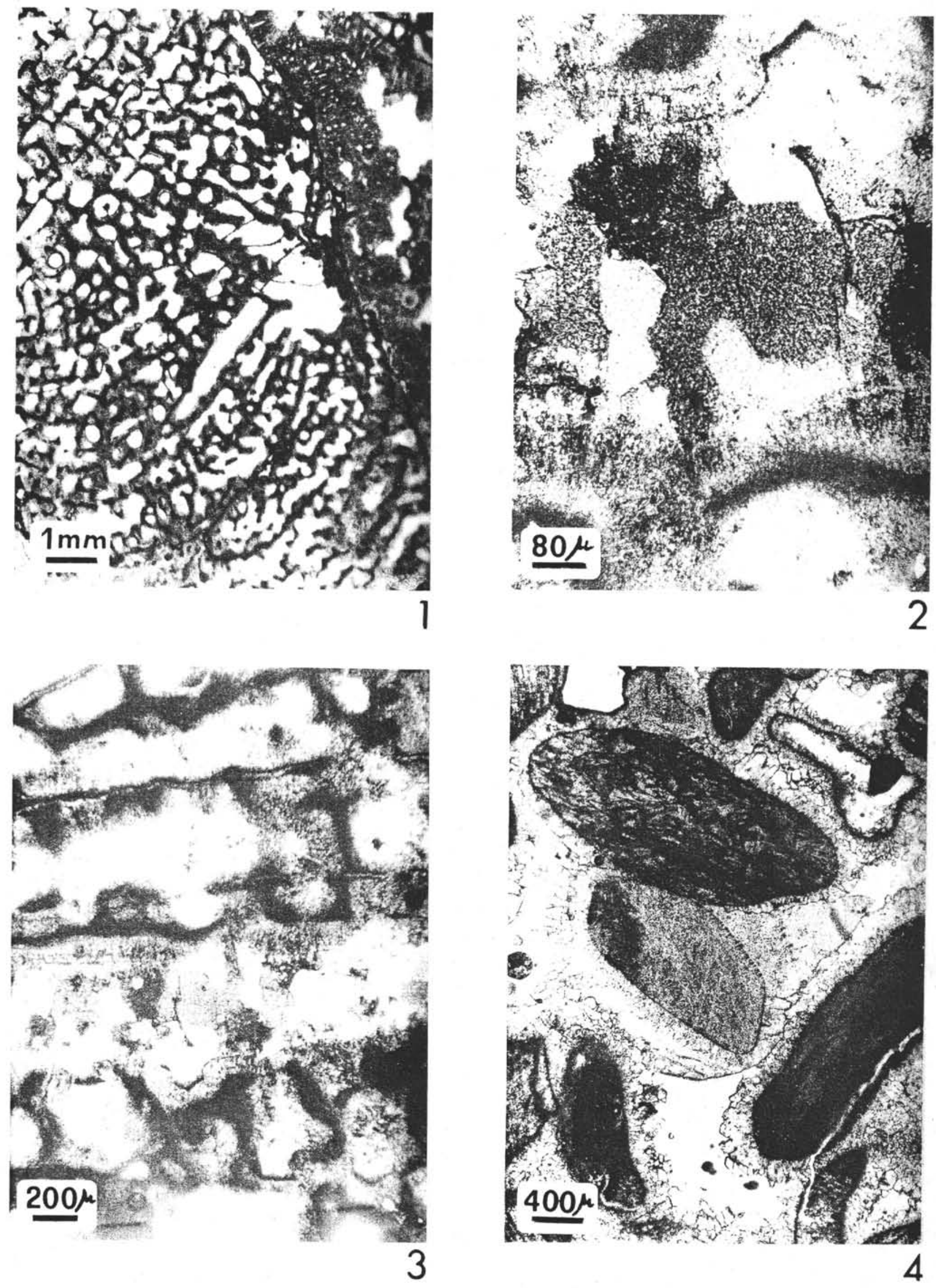


\title{
NATLAND PETROGRAPHY OF GUYOTS
}

\author{
PLATE 1 \\ Mid-Pacific Mountains \\ Horizon Guyot
}

Figure $1 \quad 7$ Tow 6 143-D-10 Basalt

Altered basalt showing plagioclase microphenocrysts and altered olivine.

Figure 2 STYX-2 Basaltic hyaloclastite

Palagonitized hyaloclastite vitrophyre showing plagioclase laths. Orange region to the right is palagonite, pale brown region to the left is sideromelane.

Figure 3 STYX-2 Basaltic hyaloclastite

Typical palagonite spherulite in hyaloclastite. This palagonite is fibrous, moderately birefringent.

\section{Menard Guyot}

Figure 4

\section{A-5-13 Hawaiite}

Slender needles of andesine and altered olivine are shown.

Figure 5

A-5-16 Scarp near Jacqueline Guyot

Basalt trelliced opaques in altered glass along with plagioclase phenocrysts and microlites, an augite phenocryst to the right and quench magnetites.

\section{Necker Ridge}

Figure 6

144-D-1 Olivine thecalite

Abundant plagioclase lesser titanaugite and iddingsite after olivine (seen very dark here) comprise this gabbro. 
PLATE 1
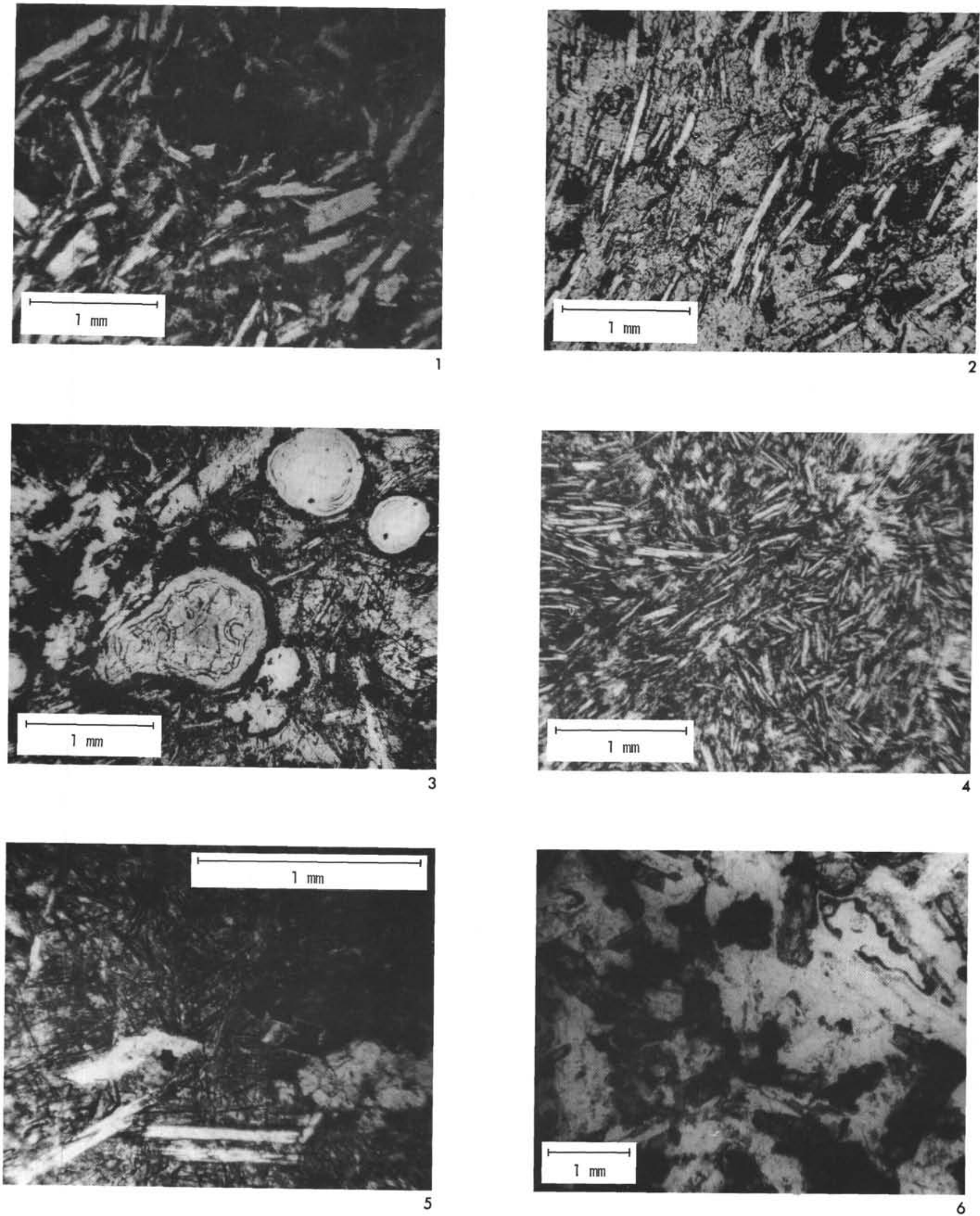


\section{PLATE 2}

\section{Wake Group}

Figure 1 A-5-19 Mugearite

Trachytic obligoclase andesite with nepheline grain, left center.

\section{Wilde Guyot}

Figure 2 A-5-20 Pricritic Limburgite

Altered olivine grains on the right, groundmass on the left with abundant titanaugite, scattered plagioclase and opaques.

\section{Miami Guyot}

Figure 3 A-5-21 Limburgite

The groundmass in this rock is predominantly titanaugite (gray) with lesser andesine (clear) and altered olivine (dark).

\section{Scripps Guyot}

Figure 4 A-5-25 Limburgite

Groundmass with abundant titanaugite and brown amphibole (kaersutite) to right.

Figure 5 A-5-27 Limburgite

Large phenocrysts of kaersutite amphibole in this section encloses apatite grains.

Figure 6 A-5-27 Limburgite

Detail of the same section with kaersutite and apatite showing the groundmass dominated by titanaugite (gray), lesser plagioclase (clear), and opaques. Some of the gray portions of this photograph are brown glass. 


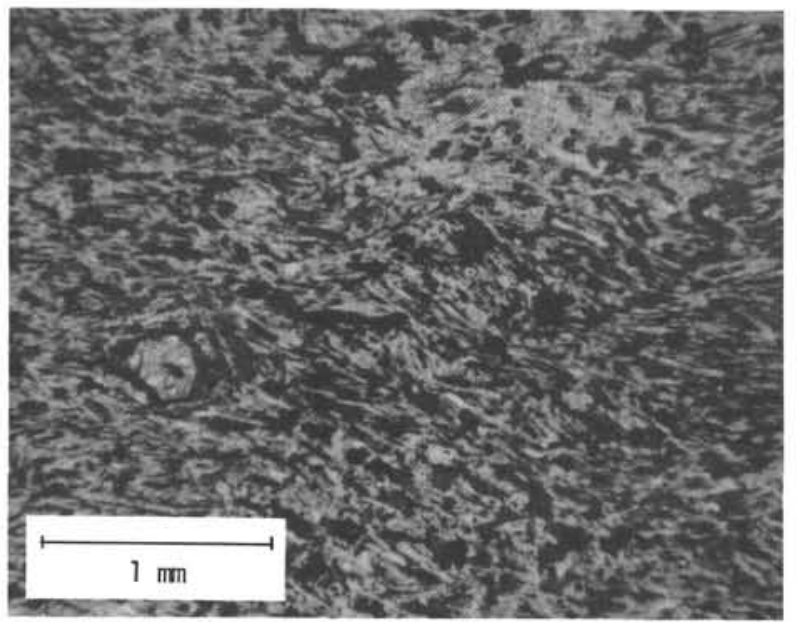

PLATE 2
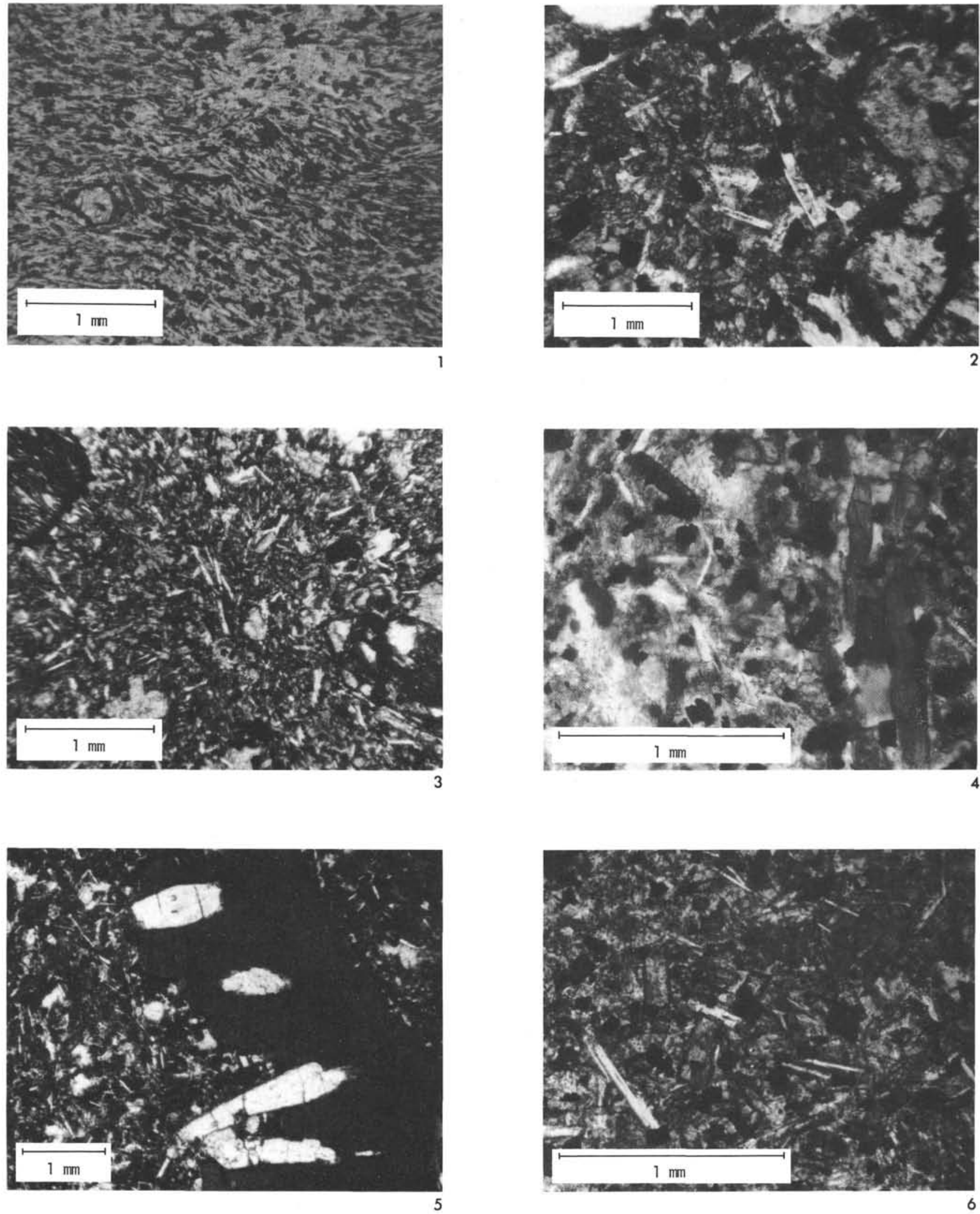


\section{PLATE 3}

\section{Ridge near Shatsky Plateau}

Figure 1

Figure 2

Figure 3

Figure 4

Figure 5
A-5-29 Basalt

Highly altered basalt showing plagioclase and augite in a dark brown altered glassy matrix.

\section{Geisha Guyots}

\section{A-5-30 Makarov Guyot Mugearite}

Oligoclase, magnetite, and clear clinopyroxene comprise this trachytic-textured rock.

A-5-36 Maiko Seamount Basalt

Iddingsite after olivine phenocrysts, plagioclase replaced by secondary sanidine and altered glass are shown.

\section{A-5-38 Seiko Guyot}

Hypersthene andesite. Synneusis twinned feldspars, augites, and hypersthene phenocrysts characterized this probably ice-rafted andesite dredged from Seiko Guyot.

\section{A-5-39 Seiko Guyot}

Trachyte dredged elsewhere on Seiko Guyot showing sanidine phenocryst and fine-grained groundmass darkened by abundant magnetite. 
PLATE 3
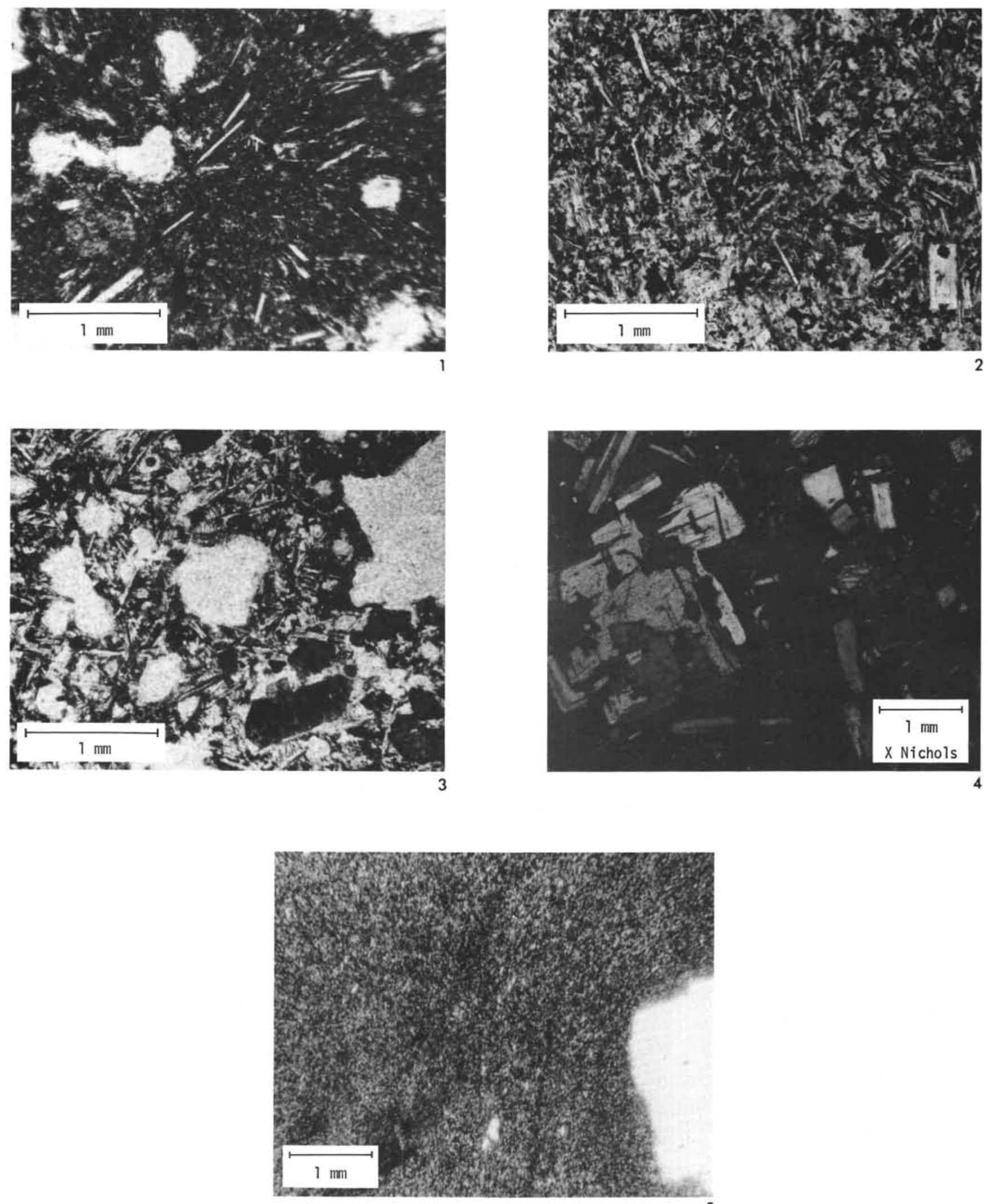